\title{
AN ECONOMIC ANALYSIS OF FEE VERSUS NON-FEE RECREATIONAL. AREAS AT THREE \\ OKLAHOMA LAKES
}

\author{
By \\ RONALD WAYNE PRESLEY \\ Bachelor of Business Administration \\ Wichita State University \\ Wichita, Kansas \\ 1970 \\ Master of Arts \\ Wichita State University \\ Wichita, Kansas \\ 1972
}

Submitted to the Faculty of the Graduate College

of the Oklahoma State University

in partial fulfillment of the requirements

for the Degree of

DOCTOR OF PHILOSOPHY

December, 1975 
Thens
19750

p934e

cope. 2 


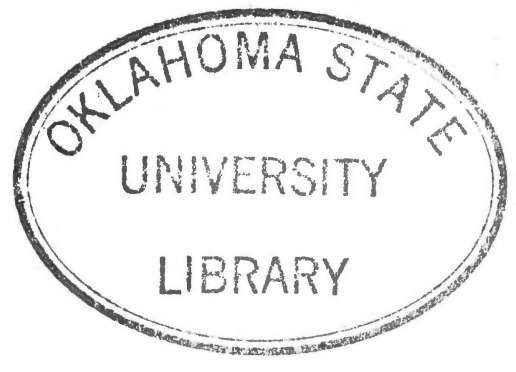

AN ECONOMIC ANALYSIS OF FEE VERSUS NON-FEE

RECREATIONAL AREAS AT THREE

OKLAHOMA LAKES

Thesis Approved:

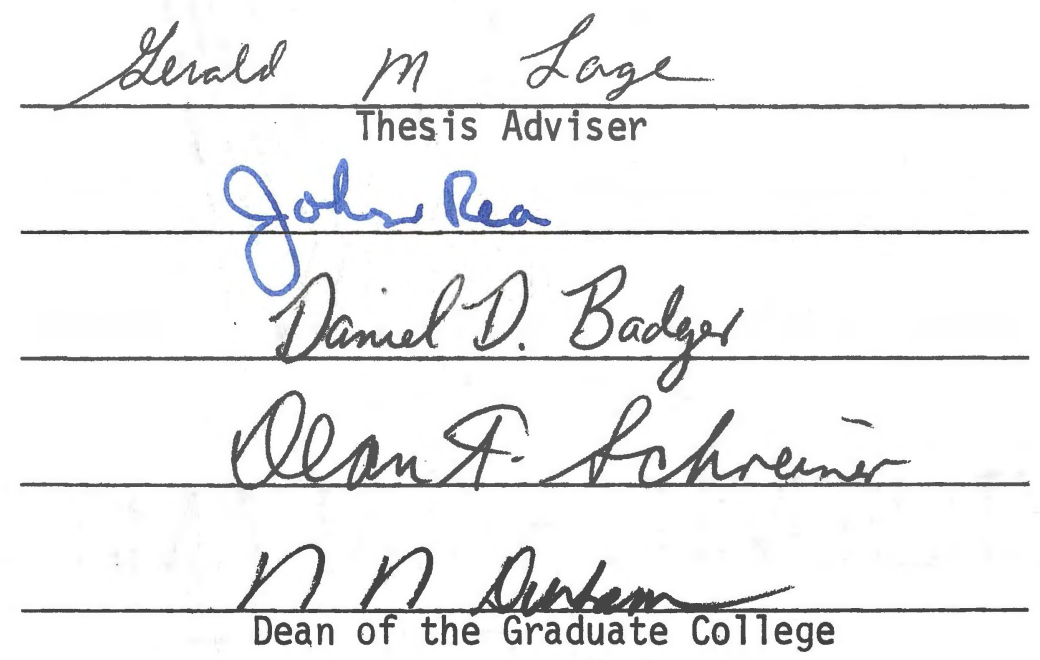

$96396 \%$ 


\section{ACKNOWLEDGMENTS}

I wish to extend my appreciation to Dr. Gerald M. Lage, Chairman of my graduate committee, for his assistance in completing this study. A special debt of gratitude is owed Dr. Daniel D. Badger for his assistance and encouragement throughout the research. Appreciation is also extended to the other committee members, Dr. John D. Rea and Dr. Dean F. Schreiner, for their valuable assistance.

I am very grateful to the Department of Agricultural Economics and the U.S. Army Engineer Institute for Water Resources for providing the financial assistance that made this study possible and to the Department of Economics for financial support during my graduate program.

Thanks are extended to Mrs. Debbie Miller for typing assistance of the rough draft, and to Mrs. Sharon Hair for typing the final copy.

Finally, the greatest debt of gratitude is owed to the author's wife Karen and his children, Karol and Ron. Their sacrifice has been the greatest. 
TABLE OF CONTENTS

Chapter

Page

I. INTRODUCTION . . . . . . . . . . . . . . . . . 1

Objectives . . . . . . . . . . . . . . . 7

The Area of Investigation . . . . . . . . . . 9

Organization of the Study . . . . . . . . . . 12

II. THE PROVISION OF WATER-BASED OUTDOOR RECREATION . . . . . . 13

The Traditional Philosophy ............ 15

The Emerging Philosophy . . . . . . . . . . . 22

Implications of Public Provision on Demand

Considerations . . . . . . . . . . 28

III. PROCEDURE . . . . . . . . . . . . . . . . . 33

Data Collection ................ 33

Procedures for Analys is of the Data . . . . . . . 36

Procedure for Estimation of Demand Curves . . . . 37

The Theoretical Model . . . . . . . . . . 42

The Empirical Model .. . . . . . . . . . . 49

The Empirical Dichotomy . . . . . . . . . . . 56

IV. ANALYSIS OF CONSUMPTION DATA AND ACTIVITIES RELATED

TO WATER-BASED OUTDOOR RECREATION . . . . . . . . . . . 60

Recreationists' Data ............. 60

Facility Preferences of Recreationists . . . . . . 73

Expenditure Patterns .............. 85

Summary .................... 92

V. EMPIRICAL ESTIMATION OF DEMAND . . . . . . . . . . . . 94

Recreation Demand Curves: Lake Tenkiller . . . . . 94

Recreation Demand Curves: Lake Eufaula and

Lake Fort Gibson . . . . . . . . . . . . . 99

Recreation Demand Curves: Pooled Data... . . . 105

A Hypothetical Experiment with Camping Fees . . . . 108

Summary ................... 113 
Chapter

Page

VI. SUMMARY AND CONCLUSIONS . . . . . . . . . . 116

Summary and Policy Implications ......... . 117

Conclusions ................. 125

Limitations and Suggestions for Further Study . . . 126

SELECTED BIBLIOGRAPHY . . . . . . . . . . . . . 130

APPENDIX A - SURVEY INSTRUMENT . . . . . . . . . 135

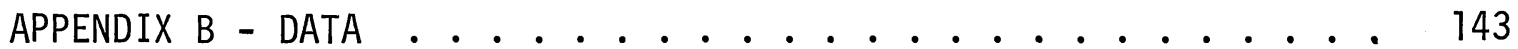




\section{LIST OF TABLES}

Table

Page

I. Annual Visitor Days and Percentage Increase for Fort

Gibson Lake, Eufaula Lake, and Tenkiller Lake:

1970 to $1974 \ldots \ldots 10$

II. Traditional Mode of Evolution of Water Resource

Projects with Emphasis on Major and Minor

Participants .............. . 21

III. Possible Mode of Evolution of Water Resource Projects

Under the Emerging Philosophy . . . . . . . . 29

IV. July and August Visitor Days (1973) and Expenditure Weights, by Lake............ 35

V. Average Number of Persons per Recreation Group by Lake, in 1974 . . . . . . . . . . . . . . 61

VI. Average Length of Stay by Lake, in 1974 . . . . . . . . 62

VII. Percentage Distribution of Recreationists by Length of Stay at Lake, in 1974 .......... . 63

VIII. Percentage Distribution of Recreationists by Distance

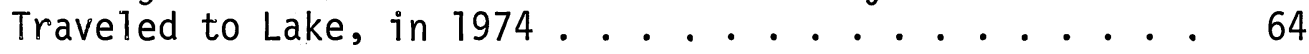

IX. Average Miles Traveled by Recreationists to Reach Lake, in 1974 .............. . . 66

X. Percentage Distribution of Respondents by Age,

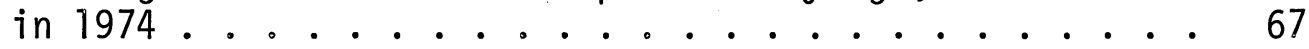

XI . Percentage Distribution of Respondents by Leve1 of Education, in $1974 \ldots . . . . . . .69$

XII. Percentage Distribution of Recreationists by

Total Household Income, in $1974 \ldots 71$

XIII. Percentage Distribution of Recreationists by

Type of Employment, in 1974 ......... 72

XIV. Percentage Distribution of Recreationists' Reasons

for Selecting a Particular Lake, in 1974 . . . . . . . 74 
Table

Page

XV. Percentage Distribution of Types of Facilities Used by Recreationists, in $1974 \ldots 77$

XVI. Percentage Distribution of Recreationists' Suggestions for Site Improvements, in $1974 \ldots . . . . .80$

XVII. Percentage Distribution of Most Important Problem Cited by Recreationists, in 1974.........

XVIII. Average Trip Expenditure Per Visitor Day by Lake, in $1974 \ldots . \ldots 86$

XIX. Average Visitor Days Per Trip by Lake, in 1974 . . . . 87

$X X$. Regression Coefficients and $t$-values for Water-Based Outdoor Recreation Demand Mode1: Lake Tenkiller . . . . 95

XXI。 Summary F-Test on Income Dummies, Lake Tenkiller . . . . 97

XXII. Summary of F-Test on Joint Hypotheses of Difference Between Non-fee and Fee Area Users, Lake Tenkiller . . . 98

XXIII. Regression Coefficients and t-values for Water-Based Outdoor Recreation Demand Model: Lake Eufaula . . . . 100

XXIV. Regression Coefficients and t-values for Water-Based Outdoor Recreation Demand Mode1: Lake Fort Gibson . . . 101

$X X V$. Summary of F-Test on Income Dummies, Lake Eufaula and Lake Fort Gibson . . . . . . . . . . 103

XXVI. Summary of F-Test on Joint Hypotheses of Difference Between Non-fee and Fee Area Users, Lake Eufaula and Lake Fort Gibson . . . . . . . . . 104

XXVII. Regression Coefficients and t-values for Water-Based Outdoor Recreation Demand Model: Lake Tenkiller, Lake Eufaula, and Lake Fort Gibson ....... . . 106

XXVIII. Summary of F-Test on Income Dummies, Pooled Data: Lake Tenkiller, Lake Eufaula, and Lake Fort Gibson . . . . 107

XXIX. Estimates of Average Attendance Per Group and Fee Revenue from An Average Group for Different Levels of Fees .............. . 111

XXX. Price Elasticity of Demand by Lake and User Group, $1974 \ldots \ldots \ldots \ldots . \ldots \ldots$ 
Table

Page

XXXI。 Regression Analysis Data: Tenkiller Lake . . . . . 145

XXXII. Regression Analysis Data: Fort Gibson Lake . . . . . 150

XXXIII. Regression Analysis Data: Eufaula Lake . . . . . . . 154 


\section{LIST OF FIGURES}

Figure

Page

1. Geographical Location in Oklahoma of Lake Fort Gibson, Lake Eufaula, and Lake Tenkiller . . . . . . . . . 11

2. A Corner Solution ................ . . 46

3. Relative Position of Three Different Demand Curves with Constant Elasticity of Demand . . . . . . . . 50

4. Typical Dollar Expenditures, Lake Fort Gibson, in 1974 . . 89

5. Typical Dollar Expenditures, Lake Eufaula, in 1974 . • . • 90

6. Typical Dollar Expenditures, Lake Tenkiller, in 1974 . . . . 91 


\section{CHAPTER I}

\section{INTRODUCTION}

The role of water-based outdoor recreation in fulfilling consumption desires of the general public is taking on new and expanded dimensions. Prerequisites to consumption are opportunity and purchasing power to engage in the recreation experience. These factors have been, and will continue to be, provided at increasing levels by economic, sociological, and technological development. Included in these developments are higher levels of income, more leisure time, and better transportation systems. Changes in tastes and preferences also have a role in this transition.

The implications of personal preferences for natural resource use are best illustrated by the demand for outdoor recreation facilities. Rates of use of outdoor recreation facilities have been increasing much more rapidly than would be indicated by increases in population and income, suggesting an increasing preference for outdoor activities (29, p. 145).

The rapid increase in reported visitations to recreation areas resulting from these developments suggest a need for expanded information systems related to water-based outdoor recreation. A recommendation made thirteen years ago by the Outdoor Recreation Resource Review Commission (ORRRC) is still well-grounded today. The Commission stated "A systematic and continuing program of research is needed to provide, the basis for wise decisions and sound management" (44, p. 183). Data collection, inventory, and factfinding; applied management research; and fundamental research were listed as continuing research needs by the commission. 
The rapidly changing nature of water-based outdoor recreation may make the commission's recommendation even more relevant today. This changing nature includes not only increased demands, but also changing demands related to the recreation experience. Recreationists now have more and better equipment (campers, boats, etc.) which require different facilities than provided at our lakes in earlier years. More of ten than in the past, modern conveniences such as air conditioners, TV's, and radios are brought along on the recreational trip. Many of these items require electricity at the campsites. As a result of this trend more electric hookups will probably be found in public use areas (PUA's) in the future. Other changing relationships could be noted and discussed (i.e., increasing numbers of sailboaters, level campsites for camping vehicles, etc.) but the point is obvious by now. A continued monitoring of data related to water-based outdoor recreation is needed to insure knowledgeable provision and management decisions.

The current function of providing water-based outdoor recreation in Oklahoma is fulfilled primarily by projects developed by the Corps of Engineers, the Soil Conservation Service, and the Bureau of Reclamation. Recreation facilities have historically been provided as a collateral benefit through the development of water resources in general. Projects which developed in the interest of navigation, flood control, water conservation and related purposes provide water impoundments which are the basis for water-based outdoor recreation. However, since Senate Document 97 was published in 1962, benefits accruing to recreation are taken into account in benefit-cost estimates.

Senate Document 97 places outdoor recreation alongside water supply, irrigation, water quality control, and seven other specific purposes for 
full consideration in project formulation and evaluation. Furthermore, the document emphasizes planning now to provide the best use of water and related land resources both in the short- and long-run (54).

Two years later in 1964 Supplement No. 1 to Senate Document 97 provided "... standards, pending further research, for the evaluation of recreation benefits from the use of recreation resources provided by water and related land development projects" (1, p. 1). The supplement established a schedule of values pertaining to a visitor day. The values ranged from $\$ 0.50$ to $\$ 1.50$ per visitor day for "general" recreation activities. Specialized use where opportunities are limited or intensity of use was low ranged from $\$ 2.00$ to $\$ 6.00$ per visitor day.

The Principles and Standards adopted by the Water Resources Council in September 1973, reinforce the role of water and related land based recreation in federal water projects. In fact, these new Principles and Standards which replace Senate Document No. 97, make an even stronger case for the role of federal agencies in recreational management (62, p.24803)。

The range of values to be placed on a recreation day were modified to: $\$ 0.75$ to $\$ 2.25$ for general recreation activities; and $\$ 3.00$ to $\$ 9.00$ for specialized recreation activities (62, p. 24804).

These "values" should not be confused with fees, which at that time were virtually nonexistent for water-based outdoor recreation. These were simply values to be used for computing benefits accruing to particular projects as a result of the recreation facilities included in the projects.

The initial emphasis on user fees was to come from the Land and Water Conservation Fund Act of 1965 which served the expressed purpose 
of Assisting,

... in preserving, developing and assuring accessibility to all citizens of the United States of America of present and future generations and visitors ... such quality and quantity of outdoor recreation resources as may be available and are necessary and desirable for individual active participation in such recreation... $(57, p, 1)$ 。

The act provides funds to assist states in developing recreation areas and provides funds for Federal acquisition and development of recreation areas.

A fund was established in the Treasury of the United States with revenues and collections to come from entrance and user fees, surplus property sales, and motorboat fuel taxes. The monies collected in the fund would then be available for expenditure on recreation purposes covered by the Act.

The Act amended the Flood Control Act of 1944 by deleting the "free" use provision contained therein. Thus, the stage was set for an increasing emphasis on recreation fees. Two general types of fees were established by the Act: (1) entrance or admission fees; (2) user fees. These fees are payable for the use of specific sites, facilities, equipment, or services. Examples include campsites, picnic areas, boat launching facilities, and firewood. The Corps of Engineers' lakes in Oklahoma charge only user fees for camping in designated areas around the lakes. No admission fees are charged.

Even though the Corps, in particular, do not charge fees other than camping fees, the Act specified a range of user fees. Camping for example ranged from $\$ 1.00$ to $\$ 3.00$ per night; Picnic sites ranged from $\$ 0.50$ to $\$ 0.75$ per site per day; Boat launching sites ranged from $\$ 0.50$ to $\$ 1.50$. These fees could not be charged unless the site contained or was within reasonable distance from other specified facilities such as access roads, parking, drinking water, and toilet facilities. 
The Federal Water Project Recreation Act (1965) provided that construction agencies such as the Corps of Engineers should encourage nonFederal agencies to operate, maintain and replace recreation facilities. This was to be accomplished on a 50-50 cost sharing basis. The Federal agency would provide one-half the cost of constructing the project while the state would provide the other half as well as all the costs of operation, maintenance and replacement (58).

The non-Federal share of construction costs can be paid back by either or both of two methods. Under one method provision of lands or facilities for the project serve as repayment. The second method provides that payment can be made, with interest, within fifty years of first facility use, for which entrance and user fees may be collected by non-Federal interests. Use of the second method means that direct beneficiaries (users) of the project recreation facilities will bear the burden of payment. This provision places greater emphasis on the role of fees as a means of providing water-based outdoor recreation. The Act establishes fees as a major instrument for financing water-based outdoor recreation facilities built since 1965.

The Land and Water Conservation Fund Act of 1965 has been amended by Pub7ic Law 93-303 in June of 1974. With this amendment, "No admission fees of any kind shall be charged or imposed for entrance into any other federally owned areas which are operated and maintained by a federal agency and used for outdoor recreation purposes" (59, p. 1). This leaves camping fees as the only type of fee used by the Corps of Engineers.

From these laws related to water-based outdoor recreation, the Corps of Engineers have formulated a working policy applying to user fees. The laws provide that fair and equitable fees be assessed the 
users of recreation facilities which are provided at substantial federal expense. Fees are assessed by the Corps of Engineers on the basis of seven criteria. They include, (1) the direct and indirect amount of federal expenditure; (2) the benefit to the recipient; (3) the public policy or interest served; (4) the comparable recreation fees charged by other federal and non-federal public agencies within the service area of the management unit at which the fee is charged; (5) the economic and administrative feasibility of fee collection; (6) the extent of regular maintenance required; and (7) other pertinent factors (55, pp. $1-2)$.

The Corps also placed an upper limit on the total daily camping fee for family camp areas. This fee "... will not exceed $\$ 4$, including electrical service" $(55, p \circ 2)$. The fee will be collected by uniformed rangers. The honor system will not be used.

These various laws have lifted water-based outdoor recreation to a prominant position in water-resource project planning. Furthermore, they have given a definite role to user fees. User fees will fulfill an important financial function in future water-based outdoor recreation projects.

The preceding discussion of several important legislative documents relative to water-based outdoor recreation alludes to the increasing importance of recreation fees. However, fees are not a universally accepted phenomenon.

In 0klahoma, for example, there are both types of water-based outdoor recreation. The first type, which historically has been the major type, pertains to free recreation facilities. In 1974, at the three lakes considered in this study, the Corps of Engineers provided 56 
public-use areas free-of-charge to the public. Included in these free parks are seven which are leased from the Corps by the State of Oklahoma. No camping fee was charged in any of the State Parks in 1974。 These seven parks are operated and maintained by the State of Oklahoma including rangers who patrol the state facilities. Recreationists using these areas are referred to as non-fee area users.

At the second type of area, fees are charged for "... certain highly developed facilities" (16, p. 47). In 0klahoma, these fees are not taken to be entrance fees. No charges are made for access to or use of the water areas. The fee applies only to those persons who stay overnight. The public use areas where such camping fees are charged are clearly designated by signs at the entrance to the park. In 0klahoma the fees are collected by uniformed rangers personally approaching each group of recreationists, or in some cases by gate attendants at the entrance to the recreation site. In 1974 the fees in 0klahoma ranged from $\$ 2.00$ to $\$ 3.00$ per campsite per night. Recreationists using this type area are referred to as fee area users.

Electricity is also available at some sites on an optional basis. Those persons choosing to use this utility are charged an additional $\$ .50$ per night. This charge applies regardless of whether the recreationist is in a designated fee area or a non-fee area.

\section{Objectives}

The course of relevant legislation in the area of water-based outdoor recreation, as well as recent experience in 0k1ahoma, indicates that 0klahomans are going to be faced with more fee areas and possibly higher fees in the future. How will recreationists respond to increasing 
fees? What recreation facilities should be provided for future recreationists? Who should supply water-based outdoor recreation facilities? Who should pay for water-based outdoor recreation facilities?

Planners and researchers in the area of water-based outdoor recreation would like to know the answers to these questions. This type of information would better equip them to make those day-to-day decisions which influence the final structure of outdoor recreation projects and policy. The present study will hopefully add to the store of knowledge on which those decisions concerning provision and management of waterbased outdoor recreation can be based.

The major objectives of this study are to:

A. Analyze the traditional aspects of providing water-based outdoor recreation by public institutions. This will include:

1. Analysis of the arguments which justify public provision of water-based outdoor recreation;

2. Analysis of the implications these arguments have on demand considerations of water-based outdoor recreation.

B. Analyze consumption activities related to water-based outdoor recreation. This will include:

1. Description of the socio-economic characteristics of users;

2. Identification of the types of facilities desired by users;

3. Analysis of the expenditure patterns of users.

C. Develop a model and estimate statistical demand curves for waterbased outdoor recreation. This will include estimation of separate recreation demand curves for fee area and non-fee area users. 
Four specific hypotheses are suggested either explicitly by the theory or implicitly by empirical considerations. These questions are critically examined by the empirical application of the model The first three hypotheses are testable hypotheses of traditional demand theory, the fourth is an outgrowth of the empirical dichotomy which divides recreationists into the two user groups.

1. Quantity demanded and own price are negatively related.

2. Quantity demanded and prices of alternative lakes are positively related.

3. Quantity demanded and income are positively related.

4. There are significantly different demand curves for non-fee and fee area users.

Hypothesis (1) states the familiar. proposition that the demand curve will slope downward to the right. Hypothesis (2) indicates that as the price of alternative water-based outdoor recreation opportunities increase, consumption of water-based outdoor recreation at a given lake will increase. Hypothesis (3) suggests that water-based outdoor recreation is a normal good. As income increases individuals are expected to increase their demand for water-based outdoor recreation. Hypothesis (4) suggests that fee area users possess identifiably different responses to changes in determinants of demand than their non-fee area counterparts.

D. Analyze implications for future water-based outdoor recreation policy as suggested by the study.

The Area of Investigation

The study was centered on three large multiple-purpose reservoirs 
in Eastern 0klahoma. A geographical perspective may be gained by referring to Figure 1. The three lakes are part of the McClellan-Kerr Arkansas River Navigation System. A11 lakes are under the jurisdiction of the Corps of Engineers, Tulsa District. The two oldest lakes in the sample are Fort Gibson Lake and Tenkiller Lake. They were both in Operation in 1953. Eufaula Lake was completed in 1965. In addition to recreation, flood control, water supply, and maintaining navigable water levels on the river system, all three lakes also provide electric power generation. These three lakes combined accounted for 13,647,000 visitor days ${ }^{1}$ in 1974. This represents a 61 percent increase during the five year period since 1970 (Table I)。

TABLE I

ANNUAL VISITOR DAYS AND PERCENTAGE INCREASE FOR FORT GIBSON LAKE, EUFAULA LAKE, AND TENKILLER LAKE: 1970 TO 1974

\begin{tabular}{lccc}
\hline & \multicolumn{2}{c}{ Visitor Days } & Percent \\
\cline { 2 - 3 } \multicolumn{1}{c}{ Lake } & 1970 & 1974 & Increase \\
\hline Fort Gibson & $2,937,100$ & $4,083,100$ & 39 \\
Eufaula & $3,214,900$ & $4,562,400$ & 42 \\
Tenkiller & $\frac{2,311,300}{\quad \text { Total }}$ & $\frac{5,001,500}{13,647,000}$ & $\frac{116}{61}$ \\
\hline
\end{tabular}

${ }^{1}$ A visitor day is a standard unit of use consisting of a visit by one individual to a water-based outdoor recreation site for recreation purposes during any portion or all of a 24-hour period measured from midnight (27, $\mathrm{p}$.4). 


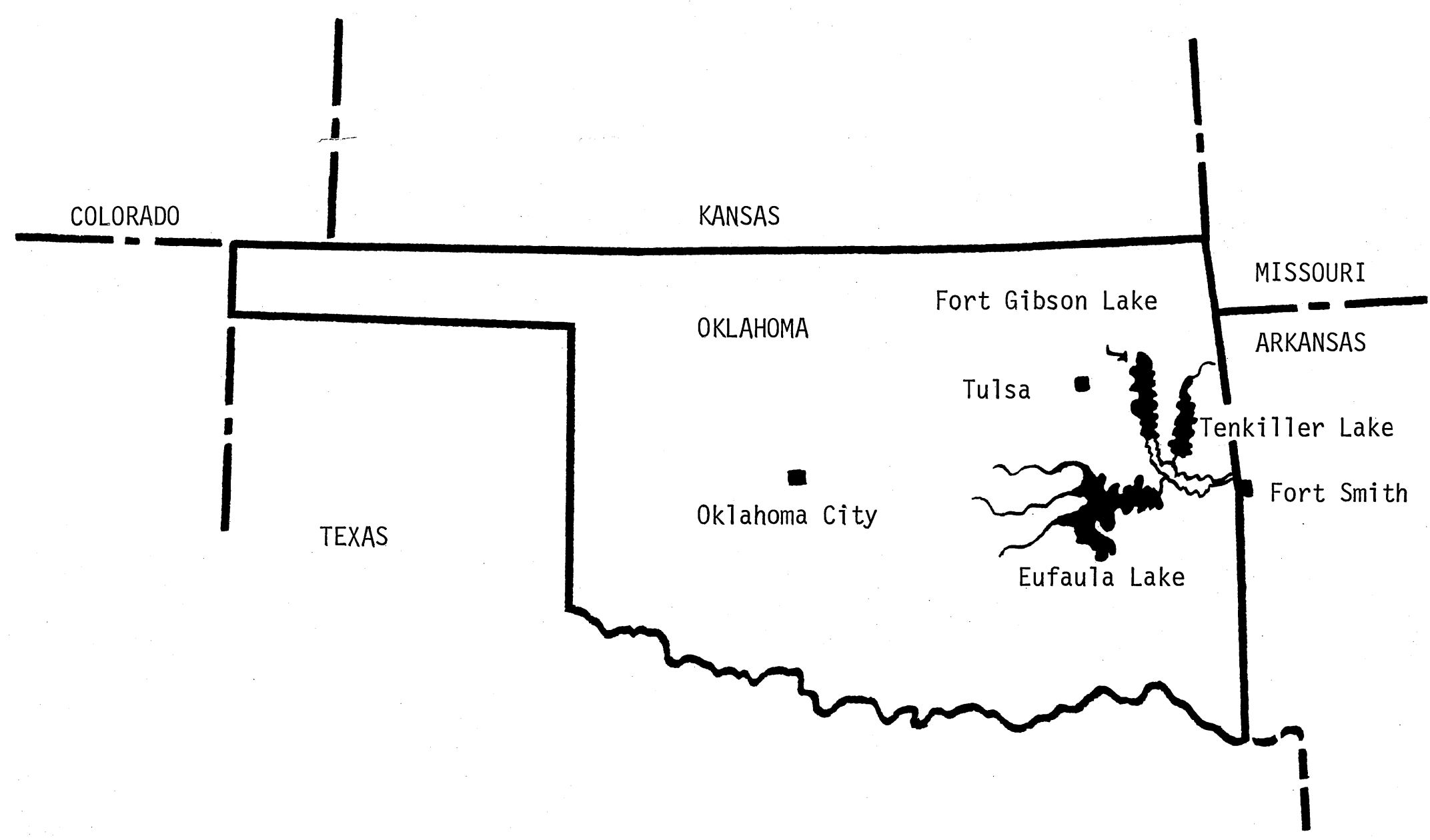

Figure 1. Geographical Location in Ok1ahoma of Fort Gibson Lake, Eufaula Lake and Tenkiller Lake 
The continued growth in recreation attendance and the projected growth for future years should serve as a caveat to policy makers, planners, and researchers concerning the increased pressures to be placed on 0klahoma's outdoor recreation resources.

$$
\text { Organization of the Study }
$$

Following this introduction, Chapter II discusses traditional arguments and philosophies related to provision of outdoor recreation and then, contrasts these with the changing views which are surfacing with respect to provision of outdoor recreation. The procedures used for data collection and analysis, including the demand model, are discussed in Chapter III. Chapter IV analyzes consumption data and activities related to water-based outdoor recreation. The empirical application of the demand model and testing of hypotheses are conducted in Chapter $V$. The summary and conclusions, including policy implications as suggested by the study, are presented in Chapter VI. 
THE PROVISION OF WATER-BASED

OUTDOOR RECREATION

In many areas of our economy a social value judgment has been made by policy makers to the effect that the exclusion principle should not be applied ( $i$.e. persons should not be excluded from consuming an item on the basis of price). These areas of the economy are characterized by public provision of goods and services. Witness, for example, the public school systems and the increased emphasis on national health insurance. Past policy in the area of water-based outdoor recreation reflects a similar value judgment. Public provision is a reality and this provision occurs at zero or near-zero prices to users (in this context these prices refer only to user fees--travel costs are not included). This public provision takes place because policy makers believe the expenditures to be made on water-based outdoor recreation are in the public interest. Steiner suggests that possibly the individual actors in the piece succomb to some extent to the representatives of government.

Nations, races, even football teams, acquire personalities and modes of behavior. ... an increasing number of economists are moving toward the view that individuals voluntarily yield certain coercive power to a government which is somehow charged to discover, articulate and implement social priorities, or collective wants (52, p. 45).

This idea must be tempered by a caveat offered by Wi1davsky, who suggests that "The process of seeking preferences may create preferences 
where none existed before" (64, p. 215). In other words, people may feel as if they have to judge an issue and thus reveal a preference without really having one, or without giving previous thought to the matter. Nevertheless, it is specifically these charges of discovery, articulation and implementation that serve to legitimize public provision of many goods and services in the name of the public interest.

The voting process is used to determine which officials are selected to be participants in the formulating aspects of public policy decisions. The voting rule assumed in this discussion is majority rule and as Musgrave has said, "The result of majority voting is optimal in the sense that it is the solution agreed to by more people than any other" (42, p. 127). Although the economics of this notion of public interest is deeply intertwined with the political process, a failure to recognize both positive and normative aspects would be less than indicative of the true nature of the concept. Positive and normative aspects must act on one another to formulate the final policy outcomes. The key actor in the process may well be the policy maker. As he operates to remove some of the restraints on new courses of action, he may have to shift preferences of interested parties to reach majority agreement. "He is engaged in a continuous and dynamic process of interplay between his own views and those of his constituency" (9, p. 153).

When considering what is in the public interest, a very wide range of possible interests or preferences must be considered in the decision making process. Inherent in this consideration is the assumption that the intensities of the preferences are revealed, even if they cannot be measured exactly. Burkhead and Minor point out the inability to compare the esthetic cost of destroying a scenic wilderness with the 
value of power and water which might be produced by a new reservior, "... but the intensity of reaction of affected groups can at least be assessed" $(9$, p. 158) in deciding which goods to include in the vector of public goods. A description of this vector which reflects the nature of the discussion on public interest is suggested by Steiner. He defines the vector of public goods as "... a vector of differences between the goods and services the private economy is motivated to provide and the goods and services the public wants, is willing to pay for, and expects its government to assist in achieving" (51, p。8). Steiner points out that this is, to a degree a normative definition but the very nature of the public interest concept contains both normative and positive influences. But where does water-based outdoor recreation fit into this vector of public goods? To answer this question the major factors which influence the public interest decision calculus as we11 as the factors which influence pricing of these goods must be considered.

\section{The .Traditional Philosophy}

Historical patterns of water-based outdoor recreation provision developed as policy makers justified public provision under the mandate of the public interest. This, with the accompanying decision to provide water-based outdoor recreation at zero or near zero prices to users encompasses a whole area of interest. The major typologies of public goods which affect the provision and pricing decisions of water-based outdoor recreation are:

1. Public goods arising because of jointness in supply, and 2. Public goods arising because of externalities. 
These typologies are found in one form or another in much of the riterature on public goods in general and outdoor recreation in particular (see for example 48 Chapter 1, and 42 p. 1-2).

Jointness in Supply

Joint supply in the public goods sense refers to the situation where one person's consumption of a good leads to no subtraction from any other person's consumption of that good. This notion of joint supply should not be confused with the multiple purpose nature of many water impoundments. Multipurpose projects provide flood control, electric power generation, and water supply at the same time they provide recreation. National defense, on the other hand, once provided, must be consumed equally by a11. The exclusion principle cannot be applied if a good takes on this strict characteristic of joint supply. The unavoidable conclusion in this case of a pure public good is that possible beneficiaries cannot in any way be excluded from consuming the good. $^{1}$

Inherent in the discussion of nonexclusion is the problem of nonrevelation of preferences. The literature on public goods is quite consistent in identifying nonrevelation as a major problem of "pricing" public goods. According to the theoretical argument, persons will not reveal their true preferences for public or even semi-public goods. If they do, they fear paying a higher price for the same quantity of goods. This is the familiar problem in the public goods literature referred to

${ }^{1}$ In the case of water-based outdoor recreation many persons would be excluded because of lack of transportation to go to the recreation area or lack of money to buy recreational equipment. 
as the "free rider" problem. Consumers wish to get a free ride, i.e. they wish to obtain the benefits of a recreation area, but they do not want to pay the full price necessary to provide those benefits. In other words, the resources forthcoming on the basis of revealed preferences will be less than needed for optimum provision. If one agrees that water-based outdoor recreation possesses this characteristic of joint supply it is but a small step to the conclusion that it should be provided by the government. This belief has led Cicchetti, et al. to conclude,

... because of the jointness in supply of most outdoor recreation, it is a public good -- as long as crowding is not a problem -- and therefore the marginal costs for users is zero. The historical decision to charge a zero (or negligible) price for the use of most outdoor recreational facilities is an economically justifiable one (12, p. 34).

In another study the joint authors conclude, "If exclusion is impossible, each recreational area takes on the characteristic of a common property resource with a uniform zero visit price to the consumer (abstracting from travel cost)" (2, p.53). So, consideration of this characteristic element of public goods and its inherent implications suggest that a voluntary exchange approach to the demand for outdoor recreation is inapplicable.

\section{Externalities}

Externalities exist when there are costs or benefits accruing to persons the value of which is not reflected in price. Externalities are subscribed to by some writers to explain why public expenditures are justified for outdoor recreation. Robinson explains the reasoning as follows, 
The logic is that productivity per worker, for the labor force of a state or the nation as a whole, is affected favorably by the existence of parks, lakes and other outdoor recreational opportunities. If this is true these facilities are in effect 'paying their way' already and it is unfair to expect them to pay their way by being priced through the usual market process (48, p。72)。

The externality argument is sometimes pushed even further. As Clawson and Knetsch explain,

This (the externality argument) asserts that recreation lessens juvenile delenquency, mental illness, and other undesirable consequences of modern 1 ife so that those not directly involved nevertheless gain a better total community life (14, p. 31).

Each of these statements on social welfare reflect the judgment that public provision of outdoor recreation is provided in the public interest. Since the benefits are not reflected in "price," too few of the goods (i.e. lakes and public use areas in the present case) would be forthcoming if not provided through public institutions.

\section{Other Arguments for Public Provision}

Other arguments reflecting the necessity of public provision of outdoor recreation include: (1) income redistribution, (2) economic development for depressed areas, and (3) conservation and preservation of natural resources. These types of arguments contain elements of great emotional appeal and are the natural genesis of interest groups which in turn interject their views into the political arena. These are areas where great intensity of feeling by a minority can result in an issue with much popular appeal.

The method of using outdoor recreation as an instrument of income redistribution has been cited as a justification for public provision. This argument jmplies that one method of dealing with an inequitable 
distribution of income is to provide parks and recreation to all consumers at zero or near zero prices. In this way, it is believed, the needy will have equal access to recreational facilities. They will not be excluded from the recreation experience simply because they are poor. The redistribution takes the form of income "in kind."

Public provision of outdoor recreation has also been suggested as a means of enhancing economic development in depressed areas. The argument notes the increasing demand pressures being placed on existing recreational facilities because of increasing urbanization. The "city folks" will want to return to the rural setting to engage in fishing, boating, and other outdoor recreational activities. Urbanization, one study concludes,

... has brought with it a decline in the economic and social condition in rural America, culminating in some areas as pockets of poverty. These emptying rural areas ... appear attractive for meeting urban recreation demand and as such have real potential for improving the welfare of these economically depressed areas (30, p. 100).

The hoped for result is a revitalization of economically depressed areas as the recreation facilities draw new consumers into the area. The recreationist wi11, the argument goes, demand many supporting goods and services thus providing an economic base for development.

Conservationists base their defense of public provision on many different contentions. The general idea that it is in the public interest, the effect of external benefits and the argument that the system benefits the poor have already been discussed. However, another of their arguments, the intergenerational argument, should be noted. This argument in its simplest form suggests that our outdoor recreation facilities are representative of all we ever will have in terms of wilderness preservation, and we must pass it on to our children. The 
only way this can be accomplished, they argue, is through government control and administration. Preservationists argue that just setting "it" aside without any use fulfills this goal. Just knowing it is there is the key.

The Synthesis

The observable result of reasoning in the manner set forth above manifests itself in traditional outdoor recreation policy. Public institutions are the major providers of most outdoor recreation facilities. These public agencies include the Bureau of Reclamation, the Tennessee Valley Authority, the Soil Conservation Service, and the Corps of Engineers, the agency primarily concerned with construction and administration of the water resource development projects which are the focal point of the present study.

An overview of the traditional framework from initiation and construction to who receives the final benefits is displayed in Table II. Table II is adapted from Bromley, Butcher, and Smith, whose expressed objective was to "... indicate the involvement of the various participants and the major actions or stages of water construction programs" $(6, p .27)$. The symbol $x$ implies major participation in a particular action; the symbol $Y$ indicates minor participation in a particular action. Initiation of a project is normally by some interest groups who stand to benefit directly from its construction. Following the arrow in Table II, the federal construction agencies are the second major participants. Then the general public becomes involved as principal bearer of cost. "In traditional patterns this was the first and in some cases the only involvement the general public had in the 


\section{TABLE II}

TRADITIONAL MODE OF EVOLUTION OF WATER RESOURCE PROJECTS WITH EMPHASIS ON MAJOR AND MINOR PARTICIPANTS

\begin{tabular}{|c|c|c|c|c|c|c|}
\hline \multirow[t]{2}{*}{$\therefore$} & \multicolumn{2}{|c|}{ Publics } & \multicolumn{4}{|c|}{ Agencies } \\
\hline & $\begin{array}{l}\text { General } \\
\text { Public }\end{array}$ & $\begin{array}{c}\text { Direct } \\
\text { Beneficiaries }\end{array}$ & $\begin{array}{l}\text { Federal } \\
\text { Construction } \\
\text { Agencies }\end{array}$ & $\begin{array}{l}\text { Loca } 1 \\
\text { Governments }\end{array}$ & $\begin{array}{l}\text { State } \\
\text { Governments }\end{array}$ & $\begin{array}{c}\text { Nonconstruction } \\
\text { Federal } \\
\text { Agencies }\end{array}$ \\
\hline Initiate & & $x-$ & $Y$ & & & \\
\hline Plan Formulation & & & $x$ & & & \\
\hline Evaluate Alternatives & & $Y$ & $x$ & $Y$ & $Y$ & $Y$ \\
\hline Select Alternative & & & $x$ & & & \\
\hline Implement Plans & & & $\forall x$ & & & \\
\hline Bear Costs & $x \leftarrow$ & & & & & \\
\hline Receive Benefits & & $\rightarrow x$ & & & & \\
\hline
\end{tabular}

Symbols: Major Role -- X; Minor Role -- Y.

Source: $(6, p .27)$ 
whole process" (6, p.28). The general public may be a secondary recipient of project benefits, but that role is filled mainly by the direct beneficiaries of the project (6, p. 28).

The Emerging Philosophy

The reevaluation of the reasoning behind traditional outdoor recreation philosophy reveals the basis for the emerging philosophy. Many of the arguments suggesting public provision at zero or near zero prices do not hold up under closer consideration. The popularity of the new philosophy is yet to be assessed but the thrust of policy will take on different objectives if the new philosophy becomes reality.

The Arguments Revisited

Reevaluation of the argument makes it difficult to justify public provision of water-based outdoor recreation because of the public good characteristic of joint supply. This notion of joint supply implies, once provided water-based outdoor recreation is equally available to a11. In fact, water-based outdoor recreation provided to one individual does reduce the amount provided to others. As Robinson explains, "If I am using a picnic table, you cannot. If I am boating on a lake, your chance to boat effectively on the same lake is reduced" (48, p. 73)。 Under this reasoning joint supply does not provide justification for free public provision of water-based outdoor recreation. Even the earlier conclusion by Cicchetti et a1., that outdoor recreation by virtue of its joint supply characteristic was a pub7ic good, was tempered by the implied nonexistence of crowding. Once crowding affects the marginal cost of supplying user space, public provision at zero cost is no longer economically justifiable. 
With respect to the impossibility, of exclusion, fences can be built or surveillance procedures can be (and in some cases already are) used to exclude non-paying users. Surveillance procedures and fee collecting techniques are currently considered in planning future recreation areas. A physical inability to exclude does not generally exist in the case of water-based outdoor recreation. Burkhead and Miner conclude on this subject, "If such exclusion is feasible ... consumers or potential consumers can be made to reveal their preferences through market arrangements" (9, $p, 31)$. This argument leans toward the notion that beneficiaries should pay their own way if in fact they can be identified.

Physical inability to exclude should not be confused with economic feasibility. In some cases the cost of collecting fees could outweigh the benefits. In such a case, the collection is not economically justified. Even in this case, however, fee collection may be justified on some other basis such as reduced crowding or less vandalism.

Milton Friedman approaches the externality argument by first defining the role of government. That role is, he says "... to do something that the market cannot do for itself, namely, to determine, arbitrate, and enforce the rules of the game" (22, p. 27). But he continues to explain that we may also want to use the government to carry out functions that might be possible through the market but because of neighborhood effects become unlikely. From this basis, Friedman justifies local parks, but he cannot "... conjure up any neighborhood effects ... that would justify governmental activity in this (national parks) area" (22, p. 31). He concludes that private enterprise will supply this kind of an activity if consumers are willing 
to pay for it. Now, it seems to be a matter of degree. Is water-based outdoor recreation closer to the local park type or the national park type?. In other words, is it possible to "conjure up any neighborhood effects" which might justify public provision. Opponents of externalities as a justification for public provision argue that if external effects are enough justification, "... then subsidy of almost any good or service imaginable would also be so justified, since ... (externalities) are present almost everywhere in the economy" (18, p. 93). Replying to the externality-increased productivity argument Robinson states,

A great many services may have externalities of consumption in the form of a favorable impact on productivity and output per worker. These include educational T.V., symphony concerts and pretzels and beer. Why should only recreation be singled out for special support (48, p. 72)?

A last and possibly fatal blow to empirical consideration of externalities is the unavoidable reality that quantifiably measuring externalities, since they are not valued in the market, eludes us. So, how do we choose between water-based outdoor recreation and pretzels and beer if we wish to maximize society's benefits (48, p. 72)? A7though the existence of externalities may be recognized by most people, a decision to publicly provide one good or service over another can be no more than a value judgment.

The redistribution argument is also on shaky ground. In fact, it can be rejected on the grounds of economic theory. It can be shown in a strict economic analys is that welfare can be increased by compensating the individual with the monetary value of any proposed income in kind (see for example 39, p.92). Furthermore, outdoor recreation is simply a product, "... it is people who may be poor ... To deal with their 
problems the first step is to identify which persons are in need of guidance or assistance" (28, p. 121). Only then can some steps be taken to assist these persons. The crucial assumption for the redistribution argument is that people already have transportation, camping equipment, boats, and other necessary equipment to actually use the "free" recreation facilities. The people who possess these things are, "... almost by definition, not from low-income groups" (48, p. 74). Until provision includes travel to and from the site as well as ancillary equipment, free recreation facilities will have little meaning to low income groups who otherwise cannot even afford to visit such facilities.

Studies have shown that low-income families have not been among the frequent users of parks. In reality, opponents argue, public financed parks are actually competing with other programs which directly aid the poor in the federal government's budget. It has been suggested that there is a regressive aspect in effect here, as general funds may in effect be providing "... playgrounds for the well to do" (18, p. 95). Noting that the very nature of a "free" recreational resource wi11 most likely lead to overcrowding and congestion, Anderson and Bonsor conclude, "The 'opportunity' to participate in overcrowded recreational experiences is a poor substitute for income redistribution" (2, p. 57). Limitations to the economic development arguments include, seasonality of employment and low earnings potential of recreation related jobs. Water-based outdoor recreation areas, in particular, are characterized by highly fluctuating visitation patterns, and local employment depends on visitors. Also, "Disguised costs are present in the form of pollution, competition with other recreation areas, and the possible 
handling of the employment situation on a more efficient basis, through enhanced mobility or direct subsidy" (23, p. 481).

In a study on Southeastern Oklahoma recreation, Mapp and Badger conclude,

... if the aim of ... public programs is to solve the underemployment and unemployment problems in such areas, the employment multipliers indicate that public expenditures to attract smal1 manufacturing activities will do much more to relieve regional unemployment than will public expenditures to develop outdoor recreational facilities $(40, p \circ 30)$.

Opponents of the intergenerational argument counter by arguing that what we have today is not all that might be available tomorrow. It is possible, they say, to restore and revitalize public areas for future generations 。

After reconsidering the traditional arguments for public provision of "free" outdoor recreation, public provision itself seems in question, but justification of "free" outdoor recreation appears to be in even greater doubt. The 1973 National Water Commission report emphasizes the need for reappraisal.

Today's major water problems were unknown when the Nation decided to assume responsibility for navigation improvements, reclamation, and flood control. Today the United States give far greater weight to environmental and esthetic values than they did when the Nation was young and less settled. They are attacking the enormous problem of controlling the pollution which befouls their rivers, lakes, and estuaries. Increasingly they are concerned with preserving the recreational values of natural water resources and developing the recreational potential of existing water projects. In short, today's conditions differ greatly from those that existed when the Nation's major water programs were created to meet the needs of an earlier era. This Commission concluded early in its life that it had no more important task than that of reappraising existing policies and programs in the light of changed conditions and demands, and of seeking guidelines for bringing the water policies and programs of the United States into harmony with the goals of a highly developed, affluent, and urban industrial nation $(43, \mathrm{p} 。 5)$. 
This statement suggests a changing philosophy with respect to water policy in general and water-based outdoor recreation in particular. Although users will be expected to pay more for the benefits they receive, it should not be concluded that provision will not be public.

Who should finance, construct, and operate various water resource developments is one question. Who should pay for them is another. The Commission believes that even where a public agency is the proper entity to finance, build, and operate a water project, directly identifiable beneficiaries should ordinarily be obliged to pay their full share of the costs of the facilities from which they benefit (43, p. 9).

One of the reasons that public agencies are the proper entity to finance, build, and operate a water project is related to the multipurpose aspects of water development projects. Flood control facilities, for example, would probably not be built at all if not by government. But once built, recreation can be a purpose of the same project.

Public provision based on social value judgments will most likely continue. However, the inability to economically justify "free" provision is beginning to show its presence. The positive aspects of waterbased outdoor recreation, those involving measurable economic value, will have more influence on deciding who pays for water-based outdoor recreation. The National Water Commission suggests beneficiaries should pay. It is not yet a reality but it is a seemingly inevitable outcome of the emerging philosophy...

This is not to say that fee policies are a completely new experience. Some states have been charging park user fees for years. Also, the National Park Service and Forest Service have charged fees for many years. However, more support for fees is being evidenced, and that support will probably grow.

What relationships will change if the emerging philosophy becomes 
reality? Using the same classification system as in Table II, Bromley et al. summarized the likely relationships which will evolve under the recommendations of the Commission. Using the National Water Commission as spokesman for the emerging philosophy, Table III, adapted from Bromley et $\mathrm{a}$ l. represents expected relationships between the various principals in what here is termed the emerging philosophy in water-based outdoor recreation.

A major change involves the cost-bearing responsibilities of direct beneficiaries. Actually, direct beneficiaries will most likely be involved at nearly all stages of development. Also, state and local governments as well as nonconstruction federal agencies such as Bureau of Outdoor Recreation, the Forest Service, and the Fish and Wildlife Service will carry significantly greater roles in most areas. Looking specifically at the "public" involvement, the general public will be relieved of cost bearing responsibilities.

Implications of Public Provision on

Demand Considerations

The exact priority of water-based outdoor recreation in a list of alternative goods subject to public provision is still not perfectly delineated Even the National Water Commission did not attempt to fit water programs into an overall priority list (43, p. 9). However, public institutions seem likely to continue as the major supplier of water-based outdoor recreation, but beneficiaries will be expected to pay a more substantial part of the costs. The question arises, however, as to what implications public provision might have on demand considerations of water-based outdoor recreation. Are there characteristics 
TABLE II I

POSSIBLE MODE OF EVOLUTION OF WATER RESOURCE PROJECTS UNDER THE EMERGING PHILOSOPHY

\begin{tabular}{|c|c|c|c|c|c|c|}
\hline & \multicolumn{2}{|r|}{ Publics } & \multicolumn{4}{|c|}{ Agencies } \\
\hline & $\begin{array}{l}\text { General } \\
\text { Public }\end{array}$ & $\begin{array}{c}\text { Direct } \\
\text { Beneficiaries }\end{array}$ & $\begin{array}{l}\text { Federal } \\
\text { Construction } \\
\text { Agencies }\end{array}$ & $\begin{array}{l}\text { Local } \\
\text { Governments }\end{array}$ & $\begin{array}{l}\text { State } \\
\text { Governments }\end{array}$ & $\begin{array}{c}\text { Nonconstruction } \\
\text { Federal } \\
\text { Agencies }\end{array}$ \\
\hline Initiate & & $x$ & Y & $x$ & $x$ & $x$ \\
\hline Plan Formulation & Y & $x$ & Y & $x$ & $x$ & $x$ \\
\hline Evaluate Alternatives & $Y$ & $x$ & Y & $x$ & $x$ & $x$ \\
\hline Select Alternatives & & $x$ & $Y$ & $x$ & $x$ & $x$ \\
\hline Implement Plans & & & $x$ & & & \\
\hline Bear Costs & & $x$ & & $x$ & $x$ & \\
\hline Receive Benefits & & $x$ & & $x$ & $x$ & \\
\hline
\end{tabular}

Symbols: Major Role -- X; Minor Role -- Y.

Source: $(6, p .29)$ 
inherent in public provision that affect demand for water-based outdoor recreation? Wi11 a traditional approach to individual demand curves be limited or rendered useless by the nature of public provision?

One of the major challenges of theory is related to the characteristic of joint supply. As noted before, the exclusion principle is not applicable to goods characterized by joint supply. The result, as theory points out, is nonrevelation of preferences. If consumers do not reveal their preferences too few resources will be forthcoming to satisfy true preferences. Demand will be understated. However, the very fact that user charges are applied suggests a belief that consumers wi11 reveal their preferences for water-based outdoor recreation. And furthermore, as has been suggested in numerous empirical investigations, consumers of water-based outdoor recreation will reveal their preferences through another device. As described in one study, "... despite the absence of market-determined prices, the individual does pay a price that reflects his marginal valuation through his travel cost to reach the site $(11, p .1109)$. From this notion evolved the much used travel cost as a price proxy in empirical investigations of demand for outdoor recreation.

The other implication of nonexclusion is the notion that the same quantity of a public good is available to a11. This implies that an individual is unable to adjust quantity taken to price. This notion was considered before, and it was concluded that one person's use of facilities did reduce another person's use. The same quantity does not remain available for a11. Furthermore a person can adjust quantity taken by simply deciding not to visit a recreation facility on a given day. This reasoning suggests the existence of a quantity variable, 
that is, a measurable unit of recreation. A common measure of this quantity, as reported in Chapter I, is the visitor day.

The effect of externalities on demand estimates can result in underestimation of demand. The empirical demand function will not reflect the positive external benefits that may exist for the rest of the community. However, the possibility of the presence of an unmeasurable item such as externalities should not deter further investigation of empirical demand functions based on quantifiable variables. The reason for modeling in the first place is to simplify complicated relationships and explain them with a few "important" variables. Exact specification of a model is not necessary to reap significant and usable results.

As the emerging philosophy, with its greater emphasis on a benefits received basis of providing water-based outdoor recreation, becomes more of a reality, the "free" provision of water-based outdoor recreation will be reduced. The actual interaction of participants will more closely approach private market organization. The benefits received aspects of the emerging philosophy is indicative of a voluntary exchange approach to demand for water-based outdoor recreation.

There are two important conclusions to reap from this summary view of the emerging philosophy. First, on the demand side, water-based outdoor recreation can be treated as a private good with all the accompanying characteristics. Second, provision of water-based outdoor recreation will most likely continue to be made by public institutions but with greater involvement by state and local governments $(58, p, 1)$.

The discussion to this point must be tempered by the recognition that the present study will deal specifically with water-based outdoor 
recreation. The assertions and implications of the discussion reviewed herein do not all apply directly to water-based outdoor recreation. Some are more pointedly related to public goods in general or outdoor recreation (a11 types) in general. With the information of the present chapter as a background, limited though it is, the next chapter wi 11 discuss procedures used in the study. 


\section{CHAPTER III}

\section{PROCEDURE}

The purpose of this chapter is to outline the procedures used in analyzing the empirical data. This includes a discussion of the procedures of data collection; procedures for data analysis; and discussion of a theoretical and an empirical model of water-based outdoor recreation demand.

\section{Data Collection}

The basic data gathering instrument for this study was a questionnaire which was personally administered by seven student-interviewers. This questionnaire is displayed in Appendix A.

The sample, although including only persons who were at least camping one night or longer is also representative of many other recreation activities. The Corps of Engineers report visitation statistics for several activities, including camping, picnicking, boating, fishing, sightseeing water-skiing and swimming. In fact, these visitations, reported by activity, were the basis for a random stratified sample. Every public use area at each of the lakes was a potential interview site. The physical restraints which had to be taken into consideration were, time remaining in the 1974 recreation season (about two months) and the availability and costs of manpower with which to conduct the surveys. Given the availability of Corps of Engineers data on visitor 
days by activity, it was decided to sample by activity group. The visitation data for each activity group was weighted by the expected dollar expenditure per visitor day for each group. These expenditure weights and visitor days for July and August of 1973 (i.e., the two months when interviews were administered in 1974) as reported by the Corps of Engineers are presented in Table IV.

The day use activities such as picnicking, sightseeing and swimming have low expenditure weights resulting in relatively fewer recreationists in the sample from those activities. This sampling procedure insures that the recreation groups analyzed in the study represent a cross-section of the different water-based outdoor recreation activities. The actual sample was provided by statisticians in Oklahoma State University's Department of Statistics. The interview teams then went to each of the designated public use areas and administered the appropriate number of questionnaires as specified by the sample procedure.

Upon completion of the questionnaire, each question was coded for adaptation to computer techniques and procedures. This procedure included various consistency tests of the punched cards in an effort to purge the data of keypunch or coding errors.

The final sample includes a total of 550 recreation groups who were interviewed on-site during the summer of 1974. Each of the study's objectives are analyzed for two user groups and appropriate comparisons are made. The first group includes al1 recreationists using public use areas in which no camping fees are charged. These recreationists are labeled non-fee area users. The second group includes recreationists using public use areas which require payment of camping fees. This group is designated, fee area users. This dual classification of users 
TABLE IV

JULY AND AUGUST VISITOR DAYS (1973) AND

EXPENDITURE WEIGHTS, BY LAKE

\begin{tabular}{|c|c|c|c|c|c|c|c|}
\hline & Camping & Picnic & Boating & Fishing & Sightseeing & Skiing & Swimming \\
\hline Fort Gibson & 325,800 & 162,900 & 108,600 & 868,800 & 118,100 & 54,300 & 54,300 \\
\hline Eufaula & 60,100 & 107,000 & 152,000 & 313,600 & 654,700 & 42,300 & 117,800 \\
\hline Tenkiller & 630,600 & 493,000 & 176,600 & 680,600 & 706,800 & 67,600 & 67,700 \\
\hline Expenditure Weights & $\$ 7.50$ & $\$ 1,50$ & $\$ 5.00$ & $\$ 5.60$ & $\$ 1.50$ & $\$ 5.00$ & $\$ 1.50$ \\
\hline
\end{tabular}


is referred to as the empirical dichotomy. Over all lakes 277 of the groups, or 50 percent, were from fee areas. There were 255 (47\%) from Tenki1ler Lake, 178 (32\%) from Fort Gibson Lake, and 117 (21\%) from Eufaula Lake. At Tenkiller Lake 56 percent of respondents were in the non-fee areas and 44 percent were in fee areas. At Fort Gibson 50 percent of the users were in non-fee areas and 50 percent in fee areas. Finally, 33 percent of the Eufaula sample were from non-fee areas and 67 percent from fee areas.

Procedures for Analys is of the Data

The primary data collected for this study can be included in one of four major classifications: (1) recreationists' socio-economic data; (2) recreationists' site preferences and opinions; (3) recreationists' expenditure data; and (4) recreationists' visitation data.

The first two categories require little additional refining before the data can be analyzed. Some characteristics or variables did require grouping before analysis could take place. Age of the respondent, for example, is classified into six age categories before analysis proceeds. Basically, however, the first two categories of data are analyzed by comparing and contrasting the frequency and/or percentage distributions of the relevant variables.

Category (3), recreationists' expenditure data, are collected on a trip basis. Thus, if the trip is for three days the recreationists food (or lodging or travel, etc.) expenditures for the three day trip are collected. The total expenditures for the trip are then divided by the number of days spent on the trip. This yields an expenditure per day for the recreation group. Then, expenditure per day is divided by the 
number of persons in the group to yield expenditures per visitor day for each of the expenditure categories. These expenditures per visitor day for each of five expenditure categories are then compared and anaTyzed by user classification.

The fourth category of data relates to recreation groups' attendance patterns. Each group is asked to estimate how many times they visit the lake in each of the 12 months of the year. Also they are asked to estimate the average number of days they stay on each visit. These two variables are multiplied together and their product is multiplied times the number of persons in the group to yield an estimate of visitor days per month for each of the recreation groups. The resulting visitor day variable is crucial to the demand analysis of the study and will be discussed further below.

\section{Procedure for Estimation of Demand Curves}

There are two basic approaches in estimating the demand for outdoor recreation. One can be identified as the concentric travel zone approach. The concentric travel zone approach is most closely associated with the work of Marion Clawson (13 and 14). The individual approach is developed from standard microeconomic theory. The individual approach is beginning to surface more frequently in recent studies $(8,24,34$, 60).

The Concentric Travel Zone Approach

The most widely used approach for estimating demand for outdoor recreation is the concentric travel zone approach. This approach involves stratifying recreationists by concentric distance zones and 
assuming that the cost of travel from any given zone to the recreation site in question is approximately equal for all recreationists in the zone $(45, p .88)$. The average number of visits from each zone are then regressed against average travel costs from each zone to yield a demand relationship (5, p.986).

Other variables which affect demand can enter the demand relationship as an average value for each particular zone. For example, average age of each zone, or average income of each zone could enter the demand equation as explanatory variables.

This model can be expressed in its simplest form as $D_{j}=f\left(P_{j}\right) . D_{j}$ is the demand for visits from persons in zone $j$, measured as average number of trips from zone $j ; P_{j}$ is price of visits for persons from zone $j$, measured as average travel cost of all persons in zone $j$ to reach the recreation site. The aggregative nature of this model is quickly recognized. Only the "composite" measure of $D$ and $P$ are used for each travel zone, representing al.1 recreationists in the zone. If ten zones were considered there would be only ten price quantity observations even though each zone would have several observations within its boundary.

Having estimated a demand curve using this technique, conclusions can then be drawn with respect to what effect an increase in user's fees will have on recreation visitations. Implicit in the analysis is the assumption that recreationists' response to a fee would be exactly the same as an equal increment to the cost of travel (45, p. 89). Secondly, a11 recreationists in a given zone are assumed to be homogeneous enough to be represented by a single measure of any particular variable.

In one of Clawson's original studies on National Parks he concludes, 
"Revenue from entrance fees continues to mount as the fee is increased. This is because the increased fee is, generally speaking, such a small percentage of the total cost of visiting the parks" (13, p. 26). He makes this conclusion on the basis of a total revenue test. He does not report the coefficient of elasticity for his estimated demand curves.

The major advantage of models of this type is their simplicity. Differences due to availability of alternatives, quality of site, or other such factors are assumed away. Also, it is a feature of aggregative models of this type to achieve high levels of explanation (i.e., high $\mathrm{R}^{2}$ ) of the dependent variable (60, p. 280).

The Individual Approach

The individual observation approach is closely related to traditional consumer behavior theory. Like the travel zone approach, travel costs are used as a proxy for price. However, there is a price and a quantity for each observation. They are not aggregated and averaged over distance zones.

The increased use of this method is due mostly to a rejection of the homogeniety assumption required of the travel zone approach. Part of this rejection of the homogeniety assumption is intuitive, as the assumption entails a loss of information. Why would you expect recreationists from the same zone to possess identical characteristics? Vickerman suggests, "... a model in which greater forecasting confidence can be placed, one with greater statistical significance of individual regression coefficients requires a household or individual based approach" (60, p。280).

A second reason for rejection is statistical in nature. Brown and 
Nawas report that efficiency of the estimated parameters can be improved by using less aggregated data (8, p. 246). They found that "... almost 12 times as large a sample would be needed to obtain the same precision from averaged observations as from the use of individual observations" (8, p. 248). This result referred to the precision of the price proxy and was confirmed for two empirical applications. The magnitude involved in this conclusion would probably vary between models, but the evidence suggests that improved estimates can be expected from less aggregated data.

Brown and Nawas found their $R^{2}$ to be less under the individual observation approach, (.604 versus .321 ) but felt more concern should be placed on the reliability of the estimated structural parameters (8, p. 248).

Gibbs and Conner estimated a demand relationship, using the individual observation approach, for an average visit to the Kissimmee River Basin recreation area in Florida (26, p. 242). They were concerned with the economic impact of both commuting recreationists and water-front property owners on the local economy. One of their objectives was to estimate "... a demand curve showing willingness of users of the area to pay measurable sums for specified amounts of recreation ..." Travel costs, on-site costs, and income were all significant in explaining recreation days per visit (the dependent variable). The coefficient of elasticity for their demand curve was equal to .05 . It is extremely inelastic. Their coefficient of determination $\left(R^{2}\right)$ was equal to .351 . It should be noted that they were not interested in relationships at the behavioral level. Their main concern was to estimate the dollar value of recreation and its impact on the local 
economy. Nevertheless, their variables may be helpful in analyzing demand for water-based outdoor recreation at a behavioral level.

In a 1975 publication Kenneth Gibbs repeats the results of a 1973 study on Florida's State Park system. The 36 State Parks in Florida were studied. Gibbs reports, "For a 10 percent change in on-site costs, including fees, an estimated 4 percent reduction in visitor days would ensue" (25, p. 21). The inelasticity of Gibbs' demand curve leads to the further conclusion that regardless of the decrease in visitor days, revenue would increase if a $\$ 1.00$ increase in fees was implemented (25, p. 2).

In each of the previously discussed studies, the application of a model of outdoor recreation demand to a particular recreation area resulted in a consistent finding with respect to elasticity. Elasticity coefficients for the different models did tend to differ slightly in terms of numerical magnitude, but all were in the range of inelastic demand. These studies suggest that an increase in fees will result in an increase in total revenue from outdoor recreation facilities.

The decision to engage in water-based outdoor recreation and therefore to use facilities associated with flat-water recreation is very much an outcome of individual or household decision making. Since "(A) behaviorally significant and meaningful model requires a behavioral unit of observation" (60, p. 280), the individual observation approach was selected for use in this study. The theory developed in this chapter evolves from traditional theory of consumer behavior. This theory is modified by research findings and techniques from the areas of outdoor recreation in general and water-based outdoor recreation in particular. Indeed, this is one of the major contributions a theoretical 
model can make to an empirical investigation. The process of structuring and specifying the model will help identify and bring together previous analysis. The theoretical model will form the basis for empirical estimation and hypothesis testing (12, p. 53). A model, based on individual observations (i.e., a recreation group) will now be developed.

The Theoretical Mode1

Recreation Group Demand Curves

The theoretical derivation of an individual's (or some other behavioral units) demand curve for water-based outdoor recreation parallels that for any other good. As Samuelson points out, "... the fundamental unit on the demand side is clearly the 'family,' and this consists of a single individual in but a fraction of the total cases" (49, p. 9). In the present study, this "fundamental unit" on the demand side is the recreation group. If our theoretical derivation is to validly parallel the theory of conventional consumer behavior, Samuelson suggests a necessary assumption.

... if within the family there can be assumed to take place an optimal reallocation of income so as to keep each member's dollar expenditure of equal ethical worth, then there can be derived for the whole family a set of well-behaved indifference contours relating the totals of what it consumes: the family can be said to act as if it maximizes such a group preference function $(49, p \cdot 21)$.

So, in the present case, assuming that an optimal reallocation of income takes place within each recreation group, the group can be said to act as if it is maximizing a group preference function. Assuming that there is a quantifiable activity, water-based outdoor recreation, which gives 
utility to the recreation groups, that activity can be expressed in a conventional utility function. ${ }^{1}$ Assuming also that there are three lakes at which the group can engage in water-based outdoor recreation, the utility function can be written:

$$
U=U\left(R_{1}, R_{2}, R_{3}, x_{j}\right)
$$

where $j=1, \ldots, n ; n=$ number of other goods.

The R's are visitor days of water-based outdoor recreation at each of the three lakes, $x_{1}$ to $x_{n}$ are other utility producing goods or activities available to the groups. If this utility function is maximized subject to a budget constraint a demand curve for water-based outdoor recreation can be obtained. The budget constraint is:

$$
Y=P_{1} R_{1}+P_{2} R_{2}+P_{3} R_{3}+P_{x 1} X_{1}+\ldots+P_{x n} X_{n}
$$

where

$$
\begin{aligned}
& Y=\text { Income } \\
& P_{1}=\text { Price of recreation at Lake } 1 . \\
& P_{2}=\text { Price of recreation at Lake } 2 . \\
& P_{3} \mp \text { Price of recreation at Lake } 3 . \\
& P_{x 1, \ldots,} P_{x n}=\text { Prices of additional goods or activities. }
\end{aligned}
$$

The basic premise of the theory of consumer behavior is the postulate of rationality. It is assumed that the consumer will choose between alternative goods or activities in a manner which will yield him as much satisfaction as possible. This implies, of course, that he has complete knowledge of the alternatives available to him and is

${ }^{1}$ This theory is developed primarily from James M. Henderson and Richard E. Quandt, Microeconomic Theory (New York, 1971), Chapter 2. 
capable of evaluating them. Henderson and Quandt summarize the postulate in three statements. They write,

The postulate of rationality is equivalent to the following statements: (1) for all possible pairs of alternatives $A$ and $B$, the consumer knows whether he prefers $A$ to $B$, or $B$ to $A$, or whether he is indifferent between them; (2) only one of the three possibilities is true for any pair of alternatives; (3) if the consumer prefers $A$ to $B$ and $B$ to $C$, he will prefer A to C $(31$, p. 8$)$.

The postulate implies only that the consumer be able to rank activities in order of preference. It is not necessary to assign a cardinal measure to the utility derived from any particular good or activity.

Given these premises, the maximization procedure continues by introducing an augmented objective function. This is the familiar Lagrangean maximization technique, which in this case yields:

$$
\begin{aligned}
& U^{*}=U\left(R_{1}, R_{2}, R_{3}, X_{j}\right)+\lambda\left(Y-P_{1} R_{1}-P_{2} R_{2}-P_{3} R_{3}-P_{x j} X_{j}\right) \\
& \text { where } j=1, \ldots, n \\
& \quad \lambda=\text { a Lagrangean multiplier }
\end{aligned}
$$

The maximizing procedure requires the first order conditions to vanish. Therefore, partially differentiating (3) with respect to each of the unknown variables yields $n+4$ equations.

$$
\begin{aligned}
& \frac{\delta U^{*}}{\delta R_{1}}=\frac{\delta U}{\delta R_{1}}-\lambda P_{1}=0 \\
& \frac{\delta U^{*}}{\delta R_{2}}=\frac{\delta U}{\delta R_{2}}-\lambda P_{2}=0 \\
& \frac{\delta U^{*}}{\delta R_{3}}=\frac{\delta U}{\delta R_{3}}-\lambda P_{3}=0 \\
& \frac{\delta U^{*}}{\delta X_{j}}=\frac{\delta U}{\delta X_{j}}-\lambda P_{X j}=0 \quad j=1, \ldots, n \\
& \frac{\delta U^{*}}{\delta \lambda}=Y-P_{1} R_{1}-P_{2} R_{2}-P_{3} R_{3}-P_{x j} X_{j}=0 \quad j=1, \ldots, n
\end{aligned}
$$


Since we have $n+4$ equations and $n+4$ unknowns, simultaneous solution of equations (4) through (8) will yield a unique solution. The relationship of interest for the present study will state $R_{1}$ as a function of own price, prices of water-based outdoor recreation at alternative lakes, income, and prices of other goods and activities. Thus, the demand curve for water-based outdoor recreation at a lake will take the general from:

$$
R_{1}=D\left(P_{1}, P_{2}, P_{3}, Y, P_{x j}\right) \quad j=1, \ldots, n
$$

It is possible that a recreationist would decide that the price of recreation at a given lake is too high. If he does, he would elect to engage in zero units of recreation at that lake. This result is described in a utility maximization framework as a corner solution. The price of water-based outdoor recreation is normally measured by some variation on travel cost. Hence, price is closely correlated with distance traveled to reach a lake. Studies have shown that after a distance ranging from 100 to 250 miles is reached, visitations fall to near zero (60, p. 285). At a price corresponding to that critical distance where visitations fall to zero, consumer behavior is characterized by an indifference curve which originates at the intersection of a budget line with the corresponding quantity axis.

Assuming only two lakes, a corner solution is presented in Figure 2. Quantity of recreation at lake 1 is measured on the vertical axis $\left(R_{1}\right)$, quantity of recreation at lake 2 is on the horizontal axis $\left(R_{2}\right)$ 。 The respective quantities of $R_{1}$ and $R_{2}$ are determined where the individual's indifference curve is co-terminal with the budget line. Assuming the indifference curve and budget line of Figure 2, the individual will take zero units of $R_{2}$ and $\bar{R}$ units of $R_{1}$. 


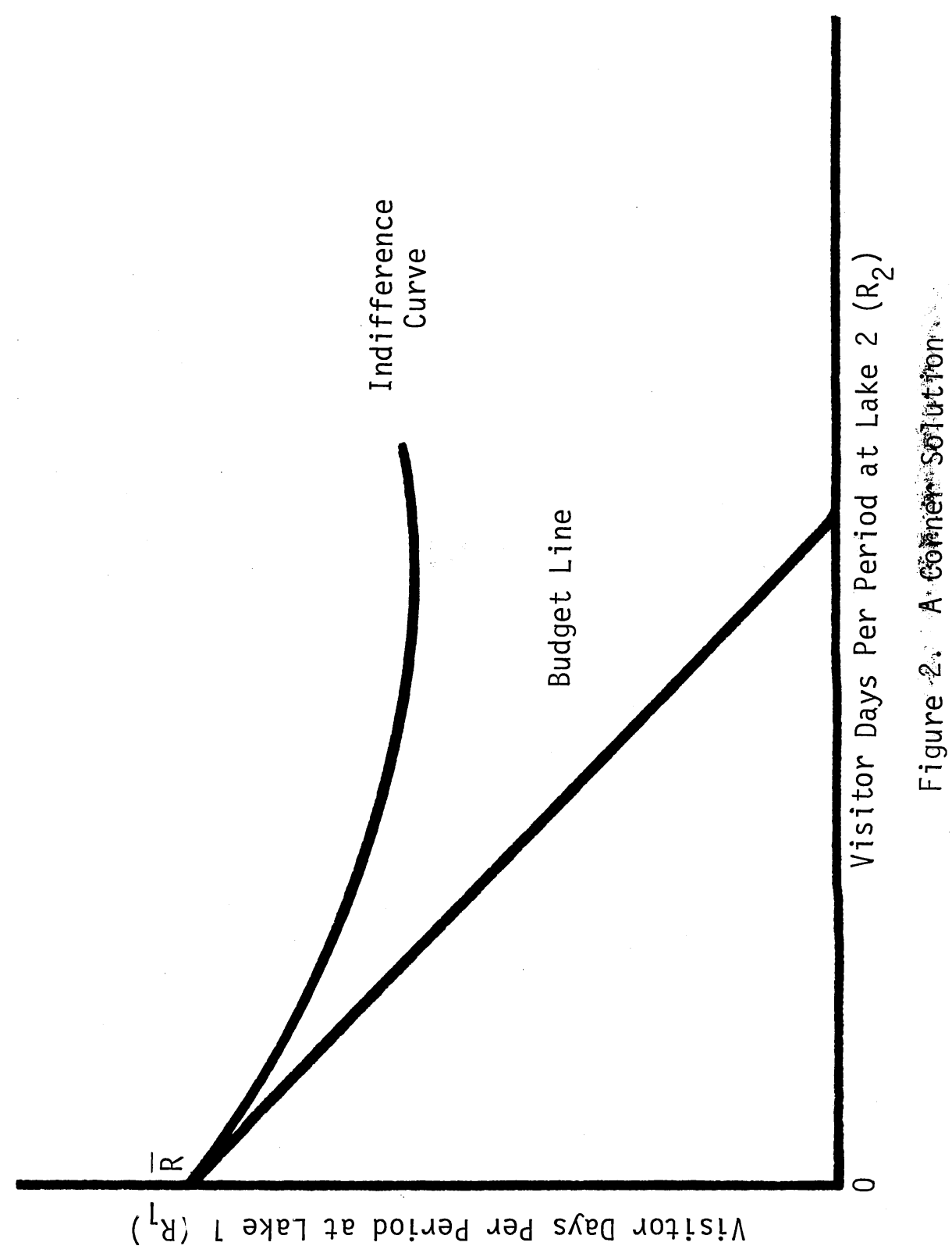


The critical price where visitations fall to zero will probably differ between lakes due to different factors of attractability and different user populations. The notion of a corner solution is a theoretical explanation of a common empirical finding in outdoor recreation research relating to this critical price.

Assuming the prices of other goods or activities are constant, $P_{x l}, \ldots, P_{x n}$ can be dropped from the model. The assumption implies that all consumers face the same constant prices for all other goods and activities. Based on this assumption equation (9) reduces to the general form:

$$
R_{1}=D\left(P_{1}, P_{2}, P_{3}, Y\right)
$$

Equation (10) is a behavioral equation written only in notational form. It indicates the quantity of water-based outdoor recreation a recreation group will take based on a decision to reach an objective (i.e. to maximize a utility function subject to the constraint of the problem). The functional form of the model has two additional important implications. First, the quantity variable $\left(R_{1}\right)$ is influenced by other variables not specified in the model. In a regression model these other variables are captured in the error term. Secondly, the functional model does not indicate the exact mathematical form of the model. This theory is a great simplification of reality, but as Walters explains, "This is, after all, the purpose of theory--to distill from a complicated reality those important elements that explain a large part of the observed phenomena" (61, p. 14). In the present study the specification of the mathematical form of the model is handled as a working hypothesis. 
The General Mode?

The selection of an appropriate equation to estimate average individual demand curves involved many structural forms. Regression analysis was used to determine which form best fit the sample data. The process resulted in the choice of the following model.

$$
R=b_{0} P_{1}^{b_{1}} P_{2}{ }^{b_{2}} P_{3}{ }^{b_{3}} e_{i}^{b_{i} D_{i}} \quad i=4,5,6
$$

This model contains all of the theoretically determined variables discussed above. The dependent variable $R$ is a measure of visitor days for the four month period June, July, August, and September; $P_{1}$ is travel costs plus fees per visitor day to the lake of interest; $P_{2}$ is the travel cost ( $i$.e. price) to an alternative lake; $P_{3}$ is the travel cost (i.e. price) to a second alternative lake; $D_{4}, D_{5}$, and $D_{6}$ are dummy variables for income.

The addition of other independent variables such as age and education did not substantially improve the explanatory power of the model and are therefore not included. However, the distributions of these types of variables are discussed in Chapter IV. The equation is estimated for both groups of recreationists as established by the empirical dichotomy 。

Equation (11) is converted to natural logarithms for the regression analysis. This procedure allows use of linear regression techniques on nonlinear data. The results of such a model are curvilinear demand curves.

The coefficients $b_{1}, b_{2}$, and $b_{3}$ are interpreted as the partial derivatives of $R$ with respect to each of the corresponding independent variables. Since the model is in logs these coefficients are elasticities. 
Constant Elasticity

Exponential models of the form used in this analysis have a constant elasticity of demand equal to the value of the exponent (35, p. 51). Figure 3 indicates three possible positions of a demand curve with constant elasticities as implied by the multiplicative model. If $b_{1}=1$ the curve is a rectangular hyperbola. If $b_{1}>1$ the curve is relatively elastic. If $0<b_{1}<1$ the demand curve is relatively inelastic.

\section{Multicollinearity}

Estimating equation (11) for each of the data sets revealed a high positive correlation between $\mathrm{P}_{2}$ and $\mathrm{P}_{3}$.

When one explanatory variable takes values that are highly dependent on another explanatory variable the data do not enable the analyst to distinguish the effects of these variables $\left(P_{2}\right.$ and $P_{3}$ in this case) on the dependent variable $(R)(53, p$. 153). The participation decision involves consideration of both alternative prices (in reality, all alternative prices) therefore each should serve to explain movements in $R$; but, with multicollinearity present, the coefficients $b_{2}$ and $b_{3}$ must be interpreted with caution.

\section{The Empirical Model}

Thus far, theory has suggested three major variables which affect demand for water-based outdoor recreation. These are, own price, prices of water-based outdoor recreation at alternative lakes, and income. A fourth variable, prices of other goods and utility producing activities was dropped from the model on the assumption that they were 


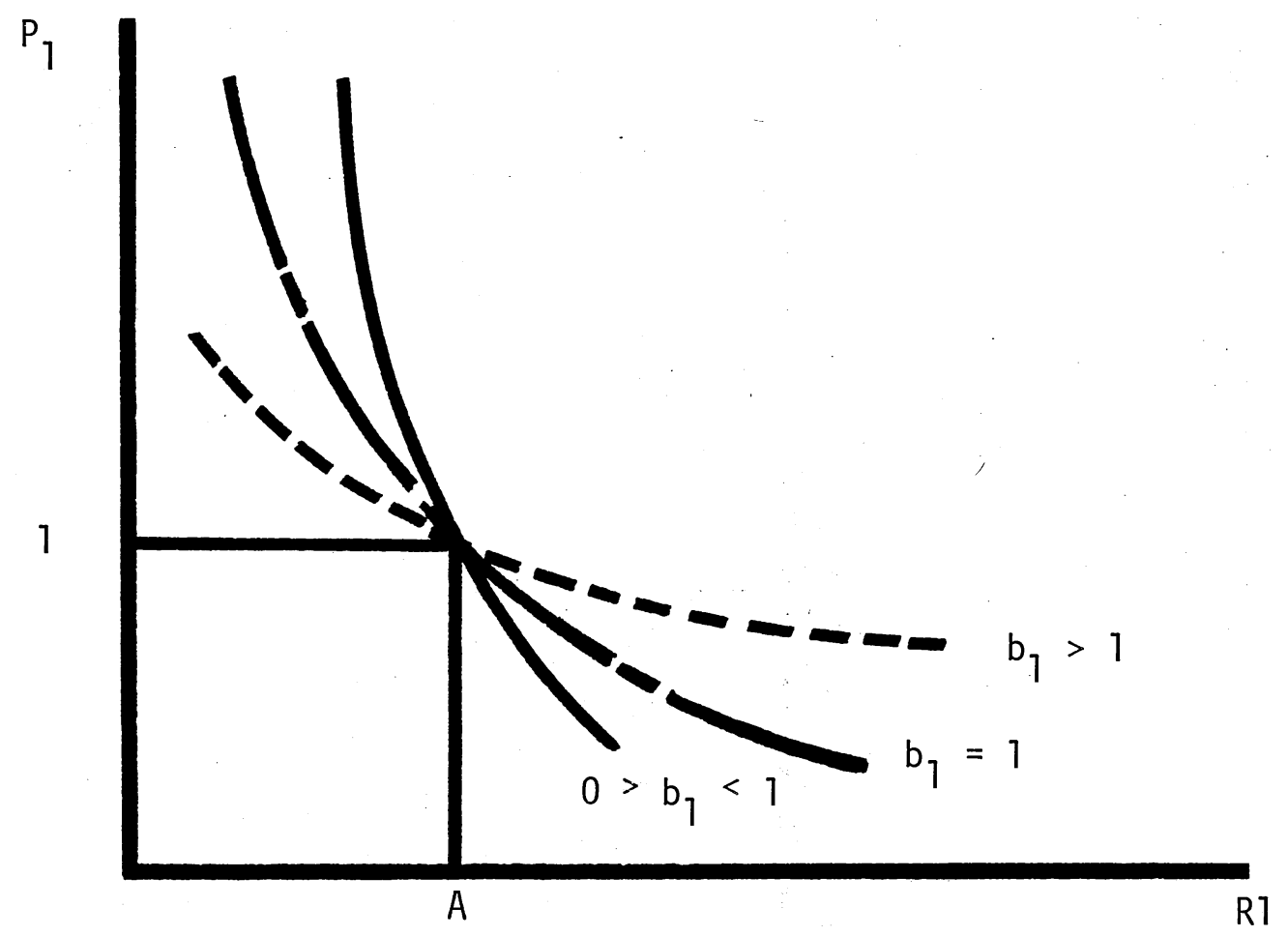

Figure 3. Relative Position of Three Different Demand Curves with Constant Elasticity of Demand 
constant. This variable would include competing types of leisure time activities. Football games or television in the fall, for example, could reduce boating in September and October while it is still warm. To this list many other variables which affect demand for water-based outdoor recreation can be added. Vickerman for example, found age and household size important (60, p. 283). Rankin and Sinden cite proportion of adults per family, average age of children, and age of household head as important determinants of demand (46, p. 425). In addition to income and age, Badger and McNeely suggest that education level might also have a role to play in recreation participation (4, p. 42). Walters responds to this issue of other variables in terms of a regression model.

Clearly, we cannot consider all these effects--it would be much too complicated and time consuming obtaining the data and doing the analysis. Theory, combined with a large slice of intuition, must help us choose which variables to include and which to reject (or lump together in the disturbance term) (61, p. 217).

The discussion now turns to empirical definitions of the theoretically determined variables.

\section{Empirical Definitions of the Variables}

Each of the variables included in equation (11) will be empirically measured by a "proxy" variable. Even though theory specified the variables to include in the regression model, a universally accepted measure of "quantity of water-based outdoor recreation" does not exist. Likewise, the price variables suffer the same problem. The income variable is normally an economically measurable unit, but the nature of its collection in this study leaves it closely associated with proxy 
type variables (19, p. 169). Rao and Miller discuss the use of proxy variables. They state,

To avoid the bias which inevitably occurs when a variable is left out, the researcher can sometimes find a variable considered to be a "close substitute" for the missing one .... The variable used as a substitute for the theoretically specified variable is called a proxy variable. Its use is quite extensive in empirical research, mainly because of the unavailability of data on some of the theoretically specified variables $(47$, p. 82$)$.

Although the use of proxy variables is widespread and reduces specification error it does introduce another problem. This malady, perhaps the most intractable of econometric problems, is labeled "errors in the variables." The problem arises because proxy variables are not exact measures of the theoretically determined variables. In short, there are errors of measurement. Therefore the interpretation of a model containing proxy variables is conditional on the closeness to which the proxy measures the "real" variable.

\section{The Quantity of Water-Based Outdoor Recreation (R)}

Measuring a unit of water-based outdoor recreation is an intangible concept which must be approached in terms of some quantifiable characteristics. Since the present study is distinguishing between non-fee and fee area users, the period of investigation is June, Juily, August, and September of 1974. Camping fees were charged at the three lakes considered in this study only during this four month period. Hence, the dichotomy of users is meaningless for the remaining months of the year. The quantity variable, $R$, is a measure of total visitor days for the recreation group during the four month period. $R$ is described by the identity, 


$$
R \equiv \sum_{i=1}^{4}\left(V_{i} \cdot L_{i} \cdot S_{i}\right)
$$

$V$ measures the number of visits per month, $L$ measures the average length of the visits, and $S$ measures the size of the recreation group. Thus, $R$ is a measure of total visitor days per group over the four month period. These visitor days, as indicated before, are representative of several different recreational activities. The relationship (12) is an identity, it does not explain. It simply summarizes the necessary mathematical computations which yield an observable measure of quantity. The computation is made for each recreation group, resulting in a series of quantity observations to be used as the dependent variable in the regression analysis.

\section{The Price of Water-Based Outdoor Recreation $\left(\mathrm{P}_{7}\right)$}

The variable $P_{1}$ is meant to reflect the price that a recreation group pays for a corresponding quantity of water-based outdoor recreation. An often used and generally accepted measure of price is some variation on travel costs (see for example 60, p. 278 and 38, p. 388). For the present study the price proxy has three component parts. Price is the summation of the travel costs to and from the lake (TC), electric utility charges (EC), and camping fees (CF). Each of these three measures are on a visitor day basis thus reflecting price per visitor day (the quantity measure). The mathematical computation of price is therefore,

$$
P_{1} \equiv(T C+E C+C F) / V D
$$

Where VD is the number of visitor days accounted for by the group during the trip when they were interviewed. TC is always greater than zero, 
but EC and CF can take the value zero; EC because use of electricity is optional and some recreationists will choose to do without electricity; CF can be zero because all public use areas do not have fees associated with camping. This computation, when made for each group, yields a series of prices representing the first independent variable in the regression mode1.

The Price of Water-Based Outdoor Recreation at Alternative Lakes $\left(P_{2}, P_{3}\right)$

$P_{2}$ and $P_{3}$ are meant to measure the price of water-based outdoor recreation at alternative lakes. Due to a lack of corresponding trip data to each alternative lake for each recreationist, $P_{2}$ and $P_{3}$ are not computationally identical to the price proxy for $\mathrm{P}_{1}$. However, information available from constructing $P_{1}$ is used along with other information to construct $\mathrm{P}_{2}$ and $\mathrm{P}_{3}$. First, travel distance to and from each recreation group's home to each of two alternative lakes are computed. Call this distance $D_{j}$, where $i$ goes from 2 to 3 indicating two alternative lakes. Then, based on each individual groups' travel costs per mile to the lake where interviewed, call it $t$, the two distance variables $\left(D_{j}\right)$ are expanded to reflect travel expenditures to alternative lakes. Thrs approach should reflect variation in costs due to different kinds of vehicles used, number of vehicles used, whether or not they are pulling a boat, and other related variations in travel cost. This measure should be superior to the often suggested measure which considers only mileage to and from the alternative lakes (see for example 5, p. 992). Mathematically,

$$
P_{i} \equiv D_{i} \cdot t \quad i=2,3
$$


Once again the computation is made for each group, yielding the alternative price series, $P_{2}$ and $P_{3}$.

If a recreation group is interviewed at Lake Tenkiller, the alternative lakes are Eufaula $\left(P_{2}\right)$ and Fort Gibson $\left(P_{3}\right)$. Therefore the prices of alternative water-based outdoor recreation (i.e. $P_{2}$ and $P_{3}$ ) refers to these two lakes. Similarly, if a group is interviewed at Eufaula the alternative lakes are Fort Gibson $\left(P_{2}\right)$ and Tenkiller $\left(P_{3}\right)$. Finally, if interviewed at Fort Gibson the alternative lakes are Eufaula $\left(P_{2}\right)$ and Tenkiller $\left(P_{3}\right)$ 。

Household Income $\left(D_{4}, D_{5}\right.$, and $\left.D_{6}\right)$

The income variable is a measure of total household income. The collection procedure required respondents to indicate in which of nine income classes their total household income was included (see questionnaire in Appendix $A)$. Hence, an aggregation of the income variable will reduce the amount of variation which would be revealed by the "actual" household income. Since the data collection procedure resulted in a "dummy" type variable (i.e. a dummy variable with an arbitrary scale), it was decided to simply reduce the nine income classes to four by using zero-one dummies. These four classes are, less than $\$ 9,000 ; \$ 9,000$ to $\$ 17,999 ; \$ 12,000$ to $\$ 14,999$; and $\$ 15,000$ and over. The dummy variable implies that the difference in mean visitor days is assumed to be attributable to differentials in income. Let $D_{4}=1$ when the observation belongs to the less than $\$ 9,000$ class, zero otherwise; $D_{5}=1$ when the observation belongs to the $\$ 9,000$ to $\$ 11,999$ class, zero otherwise, $D_{6}=1$ when the observation belongs to the $\$ 12,000$ to $\$ 14,999$ class, zero otherwise; the excluded category is $\$ 15,000$ and over. The 
coefficients of the dummy variables indicate the partial influence of each income class relative to the excluded category for given values of all the other variables.

\section{The Empirical Dichotomy}

As was stated in Chapter I, provision of water-based outdoor recreation in 0klahoma is classified into two groups: non-fee and fee. The designation of a public use area as either a fee area or a non-fee area suggests a natural dichotomy of "users". This dichotomy of respondents into fee area and non-fee area recreationists is used to compare and analyze the characteristics of the two groups and to establish similarities or differences between them. The effect of this empirical dichotomy on the multiple regression model is to require estimation of the model across two data sets. Following estimation, the two resulting demand curves are statistically tested for equality of coefficients. If the coefficients are the same for each data set this implies no difference between demand for fee area users and non-fee area users. If the coefficients are significantly different it implies that each group is characterized by different demand curves.

The dichotomy is handled in the regression model by the technique of dummy variables. Assuming, for simplicity of explanation, that prices of water-based outdoor recreation at alternative lakes are invariant, and assuming a logitnear relationship, equation (10) can be rewritten as:

$$
R=b_{0} p_{1}^{b 1} Y^{b 2} e^{E}
$$

Taking logs, and considering the empirical dichotomy there are two 
equations, one representing a non-fee area (15a) and one representing a fee area (15b).

$$
\begin{aligned}
& 1 n R=1 n b_{0}+b_{1} 1 n P_{1}+b_{2} \operatorname{lnY}+E \\
& 1 n R=1 n b_{0}++b_{1}^{1} 1 n P_{1}+b_{2}^{1} 7 n Y-E
\end{aligned}
$$

However, by introducing a dummy variable the situation may be represented with only one equation. The dummy variable will be represented by the letter. $D$. Let $D=0$ when an observation is from a non-fee area and let $D=1$ when an observation is from a fee area. Now, given the information contained in the dummy variable, equations (15a) and (15b) can be rewritten as one regression equation.

$$
\begin{aligned}
\operatorname{lnR}= & 1 n b_{0}+\alpha_{0} D+b_{1} l n P_{1}+\alpha_{1}\left(\operatorname{lnP} P_{1} \cdot D\right)+b_{2} \operatorname{lnY} \\
& +\alpha_{2}(\operatorname{lnY} \cdot D)+E
\end{aligned}
$$

Now, when $D=0$, equation (16) becomes:

$$
\operatorname{lnR}=7 n b_{0}+b_{1} l n P_{1}+b_{2} \operatorname{lnY}+E
$$

and, when $D=1$, equation (16) becomes:

$$
1 n R=\left(1 n b_{0}+\alpha_{0}\right)+\left(b_{1}+\alpha_{1}\right) 1 n P_{1}+\left(b_{2}+\alpha_{2}\right) \operatorname{lnY}+E
$$

where $\left(\ln b_{0}+a_{0}\right)=\ln b_{0},\left(b_{1}+\hat{\alpha}_{1}\right)=b \hat{1}$, and $\left(b_{2}+a_{2}\right)=b_{2}$.

Equation (16a) and (16b) are equal to (15a) and (15b) respectively (47, pp。149-50).

A necessary restriction which comes about as a result of the empirical dichotomy involves limiting the investigation to persons who are at least staying overnight. This is necessary because the fees which are charged are for camping only and therefore day users are not subject to fees. Hence the dichotomy becomes meaningless for day use activities. As far as the product "water-based outdoor recreation" is 
concerned we can now say that users are at least camping and are most likely engaged in various combinations of other activities. The dependent variable $R$ reflects these different bundles of activities.

The implication of this restriction on the $P_{1}$ variable is seen in the camping fee (CF) component. For one group, fee area users, CF will always be greater than zero, for the other it always equals zero. Electricity charges can still vary for either group depending on the individual user's desire.

The discussion to this point assumes that a recreation group's response to user fees is the same as their response to travel cost. This is so because travel costs and user fees are added together to form a single variable. Suppose, however, that the two components were separated. Let $x_{1}=$ travel costs and $x_{2}=$ user fees. $R=$ visitor days per recreation period. A simple model could be written as:

$$
R=b_{0}+b_{1} x_{1}+b_{2} x_{2}
$$

Adding and subtracting $b_{7} x_{2}$ yields,

$$
R=b_{0}+b_{1} x_{1}+b_{2} x_{2}+b_{1} x_{2}-b_{1} x_{2}
$$

which equals,

$$
R=b_{0}+b_{1}\left(x_{1}+x_{2}\right)+\left(b_{2}-b_{1}\right) x_{2}
$$

Now, assuming that the fee faced by recreationists is constant, any difference in $b_{2}$ and $b_{1}$ is reflected in the constant term $\left[i . e . b_{0}+\right.$ $\left.\left(b_{2}-b_{1}\right) x_{2}\right]$. So, if there is a difference between fee area and non-fee area user's response to fees versus travel costs it would be reflected in a different intercept. This can be handled in regression analysis by an intercept dummy. In this case of a simple model the equation becomes : 


$$
R=b_{0}+b_{1}\left(x_{1}+x_{2}\right)+b_{7} D_{7}
$$

Where $D_{7}=0$ when the observation is from a non-fee area and $D_{7}=1$ when the observation is from a fee area. If the coefficient of $D_{7}$ is significant it implies that the response to fees is not equal to the response to travel costs $\left(i \circ e, b_{2} \neq b_{1}\right)$.

Even if the fee component is not constant its coefficient $\left(b_{2}\right)$ would most likely be smaller than the coefficient of travel costs $\left(b_{1}\right)$. Since both $b_{2}$ and $b_{1}$ are expected to be negative,

$$
\left(b_{2}-b_{1}\right)=\left(-b_{2}\right)-\left(-b_{1}\right)=b_{1}-b_{2}<b_{1} \text {. }
$$

Therefore, if the response to fees is different than the response to travel cost the assumption that they are the same tends to bias estimated changes in visitor days. If $b_{1} \neq b_{2}$ visitor days would not be reduced as much by an increase in price as estimated under the assumption that they are equal. This implies that estimates of increased revenue from fees, since they are based on estimated visitor days, will also be biased downward.

In the following chapter selected socio-economic characteristics of users are described, types of facilities desired by users are discussed, and expenditure patterns of users are analyzed. 


\section{CHAPTER IV}

\section{ANALYSIS OF CONSUMPTION DATA AND ACTIVITIES RELATED TO WATER-BASED OUTDOOR RECREATION}

In this chapter respondents are classified into fee area and nonfee area users and each group is analyzed with respect to different characteristics, desires, and expenditure patterns. Also, respondents are separated on the basis of lakes. Over all three lakes 277 , or 45 percent of the recreation groups are from fee areas. Since all individuals did not answer all questions, totals for different tables at any particular lake may not be equal, Only respondents are reflected in the distributions. Due to rounding errors all totals may not sum to 100 percent.

The following sections summarize the responses of recreationists to various questions of interest. These selected variables are part of the information obtained from the interviews with recreationists.

\section{Recreationists' Data}

\section{Average Size of Group}

The average size of the recreation group, for each lake by user classification is presented in Table V. At Fort Gibson Lake the sample represents an average size group of 3.5 persons. Broken down by non-fee versus fee area users the average size of group is 3.3 and 3.7 persons respectively. 
TABLE $V$

AVERAGE NUMBER OF PERSONS PER RECREATION GROUP

BY LAKE IN 1974

\begin{tabular}{lccc}
\hline \multicolumn{1}{c}{ Lake } & Non-fee Areas & Fee Areas & Total \\
\hline Fort Gibson & 3.3 & 3.7 & 3.5 \\
Eufaula & 3.8 & 3.6 & 3.7 \\
Tenkiller & 4.0 & 4.6 & 4.3 \\
\hline
\end{tabular}

Eufaula Lake is represented by a slightly larger average size of group than Fort Gibson. Computed over all users the average size group at Eufaula consisted of 3.7 persons. However, unlike Fort Gibson, nonfee area users had a slightly larger group size compared to fee area groups. The average size group of the Tenkiller Lake sample is 4.3 persons per group. There is a smal1 difference between non-fee and fee area users. These averages must be tempered by the recognition that day use is eliminated from the sample. If it were included the average size of group would probably be smaller.

\section{Length of Stay}

Average length of stay at Fort Gibson Lake is 5.2 days; 6.3 days for non-fee groups; and slightly more than 4 days for fee area users (Table VI). The average length of stay at Eufaula was 5.0 days, with slightly shorter trips characteristic of non-fee users. Tenkiller Lake users averaged 6.6 days per trip, with slightly longer trips registered by non-fee users. 
TABLE VI

AVERAGE LENGTH OF STAY BY LAKE

IN 1974 (DAYS)

\begin{tabular}{lccc}
\hline Lake & Non-fee Areas & Fee Areas & Total \\
\hline Fort Gibson & 6.3 & 4.1 & 5.2 \\
Eufaula & 4.6 & 5.1 & 5.0 \\
Tenkiller & 6.7 & 6.5 & 6.6 \\
\hline
\end{tabular}

A different view of length of stay is presented in Table VII. Eufaula Lake and Tenkiller Lake have very similar overall distributions. There are minor differences in the distributions for fee area and nonfee area users, especially at Eufaula, but the differences are small. Fort Gibson Lake had many more one night campers than either of the other two lakes. This might be expected however from the fact that 52 percent of their visits came from the shortest distance zone (Table VIII). Recreationists traveling only a short distance are probably not as likely to feel the need for a long visit as those recreationists who invest considerable travel time to reach the lake.

\section{Travel Zones}

The percentage distribution of recreationists with respect to miles traveled to reach the recreation site is presented in Table VIII. Immediately differences between non-fee and fee area users as well as differences between lakes become apparent. Fort Gibson Lake for example 


\section{TABLE VII}

PERCENTAGE DISTRIBUTION OF RECREATIONISTS BY LENGTH OF STAY AT LAKE, IN 1974

\begin{tabular}{|c|c|c|c|c|}
\hline \multirow[b]{2}{*}{ Lake } & \multirow[b]{2}{*}{ Area } & \multirow[b]{2}{*}{ Observations } & \multicolumn{2}{|c|}{$\begin{aligned} \text { Percent By } \\
\text { Length of Stay }\end{aligned}$} \\
\hline & & & $\begin{array}{l}\text { One } \\
\text { Night }\end{array}$ & $\begin{array}{l}\text { More Than } \\
\text { One Night }\end{array}$ \\
\hline Fort Gibson & $\begin{array}{l}\text { Non-fee } \\
\text { Fee } \\
\text { Total }\end{array}$ & $\begin{array}{r}89 \\
89 \\
178\end{array}$ & $\begin{array}{l}24 \\
24 \\
24\end{array}$ & $\begin{array}{l}76 \\
76 \\
76\end{array}$ \\
\hline Eufaula & $\begin{array}{l}\text { Non-fee } \\
\text { Fee } \\
\text { Total }\end{array}$ & $\begin{array}{r}39 \\
78 \\
117\end{array}$ & $\begin{array}{r}18 \\
9 \\
12\end{array}$ & $\begin{array}{l}82 \\
91 \\
88\end{array}$ \\
\hline Tenkiller & $\begin{array}{l}\text { Non-fee } \\
\text { Fee } \\
\text { Total }\end{array}$ & $\begin{array}{l}145 \\
110 \\
255\end{array}$ & $\begin{array}{l}15 \\
10 \\
13\end{array}$ & $\begin{array}{l}85 \\
90 \\
87\end{array}$ \\
\hline
\end{tabular}


TABLE VIII

PERCENTAGE DISTRIBUTION OF RECREATIONISTS BY DISTANCE TRAVELED TO LAKE, IN 1974

\begin{tabular}{|c|c|c|c|c|c|c|c|}
\hline \multirow[b]{2}{*}{ Lake } & \multirow[b]{2}{*}{ Area } & \multirow[b]{2}{*}{ Observations } & \multicolumn{5}{|c|}{$\begin{array}{l}\text { Percent By Travel Zones } \\
\text { In Miles From Lake }\end{array}$} \\
\hline & & & $0-50$ & $51-100$ & $101-150$ & $151-200$ & $\begin{array}{l}\text { Over } \\
200\end{array}$ \\
\hline Fort Gibson & $\begin{array}{l}\text { Non-fee } \\
\text { Fee } \\
\text { Total } 1\end{array}$ & $\begin{array}{r}89 \\
89 \\
178\end{array}$ & $\begin{array}{l}38 \\
66 \\
52\end{array}$ & $\begin{array}{l}29 \\
20 \\
25\end{array}$ & $\begin{array}{r}12 \\
6 \\
9\end{array}$ & $\begin{array}{r}10 \\
3 \\
7\end{array}$ & $\begin{array}{r}11 \\
5 \\
7\end{array}$ \\
\hline Eufaula & $\begin{array}{l}\text { Non-Fee } \\
\text { Fee } \\
\text { Tota } 1\end{array}$ & $\begin{array}{r}39 \\
78 \\
117\end{array}$ & $\begin{array}{l}30 \\
19 \\
23\end{array}$ & $\begin{array}{l}25 \\
19 \\
21\end{array}$ & $\begin{array}{l}30 \\
49 \\
43\end{array}$ & $\begin{array}{l}0 \\
9 \\
6\end{array}$ & $\begin{array}{r}15 \\
4 \\
7\end{array}$ \\
\hline Tenkiller & $\begin{array}{l}\text { Non-fee } \\
\text { Fee } \\
\text { Tota } 1\end{array}$ & $\begin{array}{l}145 \\
110 \\
255\end{array}$ & $\begin{array}{l}17 \\
15 \\
16\end{array}$ & $\begin{array}{l}27 \\
25 \\
26\end{array}$ & $\begin{array}{l}13 \\
19 \\
16\end{array}$ & $\begin{array}{l}30 \\
25 \\
28\end{array}$ & $\begin{array}{l}13 \\
16 \\
14\end{array}$ \\
\hline
\end{tabular}


is characterized by having 66 percent of fee area users coming from 50 miles or 1ess. Only 38 percent of non-fee area users came from 50 miles or less. Overal1 52 percent of the total Fort Gibson sample came from the 50 miles or less range. Only 23 percent of the Eufaula Lake sample and 16 percent of the Tenkiller Lake sample came from 50 miles or less. Eufaula Lake is characterized by relatively more visitors from the 101-150 mile range. In fact, the sample shows 43 percent of Eufaula's visits from this distance zone. Tenkiller's largest representation (28\%) comes from the 151-200 mile range whereas 26 percent are from the 51-100 mile range. In each case the occurrence of larger numbers of visitors from a particular distance zone is associated with the presence of a large urban area in the zone. Fort Gibson Lake for example shows its largest visitation from the 0-50 mile range, which also includes the city of Tulsa. At Lake Eufaula 43 percent of the visitations come from the zone (101-150 miles) which includes 0klahoma City. An additional 21 percent come from the Tulsa area (51-100 miles). Hence, 64 percent of Eufaula's recreation groups are accounted for by areas containing the two largest 0klahoma cities. Although Tenkiller is characterized by more evenly distributed visits over the travel zones, over half of al1 visits are accounted for by Tulsa with 26 percent in the 51-100 mile range and $0 k 1$ ahoma City with 28 percent in the 151-200 mile range. These figures al1 point to the same conclusion, i.e. the presence of a large urban area provides the population base from which a great deal of the demand for water-based outdoor recreation will come.

Average miles traveled to reach the lake are presented in Table IX. Tenkiller Lake is characterized by the longest average miles traveled with 143 miles. Eufaula ranks second at 122 miles; Fort Gibson ranks 
last with an average of 109 miles. Since these are one way distances, the average recreation group at Tenkiller travels nearly 300 miles to engage in the recreation experience. Non-fee area users are likely to travel further to reach either Fort Gibson Lake or Eufaula Lake than their fee area counterparts. At Tenkiller Lake the fee area users travel further, on average, than the non-fee users.

TABLE IX

AVERAGE MILES TRAVELED BY RECREATIONISTS

TO REACH LAKE IN 1974

\begin{tabular}{lccc}
\hline Lake & Non-fee Areas & Fee Areas & Total \\
\hline Fort Gibson & 140 & 79 & 109 \\
Eufaula & 130 & 119 & 122 \\
Tenkiller & 134 & 155 & 143 \\
\hline
\end{tabular}

Age

The age distribution of the person interviewed for six age categories which, with the exception of the first and the last, represent ten year intervals are presented in Table $X$. The overall distribution is very similar between lakes, but differences do occur when analyzed at the fee and non-fee level. The relatively largest number of fee area users occur in the two age categories encompassed in the 30 to 49 
TABLE $X$

PERCENTAGE DISTRIBUTION OF RESPONDENTS BY AGE, IN 1974

\begin{tabular}{|c|c|c|c|c|c|c|c|c|}
\hline \multirow[b]{2}{*}{ Lake } & \multirow[b]{2}{*}{ Area } & \multirow[b]{2}{*}{ Observations } & \multicolumn{6}{|c|}{ Percent by Age Groups } \\
\hline & & & $\begin{array}{l}19 \text { and } \\
\text { Under }\end{array}$ & $20-29$ & $30-39$ & $40-49$ & $50-59$ & $\begin{array}{c}60 \text { and } \\
\text { Over }\end{array}$ \\
\hline Fort Gibson & $\begin{array}{l}\text { Non-fee } \\
\text { Fee } \\
\text { Total }\end{array}$ & $\begin{array}{r}89 \\
89 \\
178\end{array}$ & $\begin{array}{l}0 \\
1 \\
0\end{array}$ & $\begin{array}{r}15 \\
9 \\
12\end{array}$ & $\begin{array}{l}25 \\
28 \\
26\end{array}$ & $\begin{array}{l}25 \\
26 \\
25\end{array}$ & $\begin{array}{l}11 \\
21 \\
16\end{array}$ & $\begin{array}{l}25 \\
15 \\
20\end{array}$ \\
\hline Eufaula & $\begin{array}{l}\text { Non-fee } \\
\text { Fee } \\
\text { Total }\end{array}$ & $\begin{array}{r}39 \\
78 \\
117\end{array}$ & $\begin{array}{l}3 \\
1 \\
2\end{array}$ & $\begin{array}{l}15 \\
21 \\
19\end{array}$ & $\begin{array}{l}10 \\
28 \\
22\end{array}$ & $\begin{array}{l}23 \\
28 \\
27\end{array}$ & $\begin{array}{l}26 \\
13 \\
17\end{array}$ & $\begin{array}{r}23 \\
9 \\
14\end{array}$ \\
\hline Tenkiller & $\begin{array}{l}\text { Non-fee } \\
\text { Fee } \\
\text { Total }\end{array}$ & $\begin{array}{l}145 \\
110 \\
255\end{array}$ & $\begin{array}{l}1 \\
2 \\
1\end{array}$ & $\begin{array}{r}17 \\
5 \\
12\end{array}$ & $\begin{array}{l}27 \\
30 \\
28\end{array}$ & $\begin{array}{l}28 \\
40 \\
33\end{array}$ & $\begin{array}{l}17 \\
15 \\
16\end{array}$ & $\begin{array}{r}11 \\
8 \\
10\end{array}$ \\
\hline
\end{tabular}


year range. This finding is consistent over all lakes. The trend then reverses, with the exception of Fort Gibson, as relatively more persons 50 years old and older seem to prefer the non-fee areas. This statement does not hold for Fort Gibson until 60 years of age is reached.

These data suggest that while age may not influence selection of one lake over another, age may be related to why a recreationist selects a fee area over a non-fee area or vice versa.

\section{Education}

Analysis of the education level of the respondents indicates relatively similar distributions of education level obtained. Tenkiller is characterized by relatively more respondents (i.e. 40\%) with more than a high school education (Table XI). Twenty-nine percent of the Fort Gibson and Eufaula samples reported education levels greater than high school. There are no significant differences between fee area and nonfee area users except for one category at Eufaula where 46 percent of non-fee area users are in the less than high school classification compared to only 17 percent of fee area users in the same class. Considering all recreationists, about 75 percent or more have at least a high school education, with 30 percent or more having at least some college training. This can be compared with about 51 percent of all Oklahomans with at least a high school education and approximately 25 percent of $0 \mathrm{klahomans}$ with some college education (56). These findings suggest that persons with higher education were more likely to engage in water-based outdoor recreation than those persons with less education. 
TABLE XI

PERCENTAGE DISTRIBUTION OF RESPONDENTS BY LEVEL OF EDUCATION, IN 1974

\begin{tabular}{|c|c|c|c|c|c|c|c|c|}
\hline \multirow[b]{2}{*}{ Lake } & \multirow[b]{2}{*}{ Area } & \multirow[b]{2}{*}{ Observations } & \multicolumn{6}{|c|}{ Percent by Level of Education } \\
\hline & & & $\begin{array}{l}\text { Less than } \\
\text { High School }\end{array}$ & $\begin{array}{c}\text { High } \\
\text { School }\end{array}$ & $\begin{array}{l}\text { Some } \\
\text { College }\end{array}$ & $\begin{array}{l}\text { Bachelor } \\
\text { Degree }\end{array}$ & $\begin{array}{l}\text { Masters } \\
\text { or Ph.D. }\end{array}$ & $\begin{array}{l}\text { Technical } \\
\text { or Other }\end{array}$ \\
\hline Fort Gibson & $\begin{array}{l}\text { Non-fee } \\
\text { Fee } \\
\text { Total }\end{array}$ & $\begin{array}{r}89 \\
89 \\
178\end{array}$ & $\begin{array}{l}26 \\
24 \\
25\end{array}$ & $\begin{array}{l}42 \\
49 \\
46\end{array}$ & $\begin{array}{l}18 \\
17 \\
17\end{array}$ & $\begin{array}{l}6 \\
1 \\
3\end{array}$ & $\begin{array}{l}1 \\
4 \\
3\end{array}$ & $\begin{array}{l}8 \\
4 \\
6\end{array}$ \\
\hline Eufaula & $\begin{array}{l}\text { Non-fee } \\
\text { Fee } \\
\text { Total }\end{array}$ & $\begin{array}{r}39 \\
78 \\
117\end{array}$ & $\begin{array}{l}46 \\
17 \\
27\end{array}$ & $\begin{array}{l}36 \\
49 \\
44\end{array}$ & $\begin{array}{l}10 \\
15 \\
14\end{array}$ & $\begin{array}{l}8 \\
9 \\
9\end{array}$ & $\begin{array}{l}0 \\
1 \\
1\end{array}$ & $\begin{array}{l}0 \\
8 \\
5\end{array}$ \\
\hline Tenkiller & $\begin{array}{l}\text { Non-fee } \\
\text { Fee } \\
\text { Total }\end{array}$ & $\begin{array}{l}145 \\
110 \\
255\end{array}$ & $\begin{array}{l}13 \\
12 \\
13\end{array}$ & $\begin{array}{l}45 \\
49 \\
47\end{array}$ & $\begin{array}{l}19 \\
21 \\
20\end{array}$ & $\begin{array}{r}12 \\
9 \\
11\end{array}$ & $\begin{array}{l}7 \\
7 \\
7\end{array}$ & $\begin{array}{l}3 \\
2 \\
2\end{array}$ \\
\hline
\end{tabular}


Income

Household income, as indicated before, is one of the theoretically determined variables which are expected to influence demand for waterbased outdoor recreation. Approximately 72 percent, 77 percent, and 85 percent respectively for Fort Gibson, Eufaula, and Tenkiller recreationists reported family incomes of $\$ 9,000$ or more (Table XII). These figures can be compared with approximately 41 percent for residents of Oklahoma in general (56). The median income level for respondents at Fort Gibson and Eufaula was in the $\$ 9,000$ to $\$ 11,999$ income class. For Tenkiller the median income was one class higher in the $\$ 12,000$ to $\$ 14,999$ range. These figures are considerably higher than the $\$ 7,725$ median household income for residents of $0 \mathrm{klahoma}(56)$. It appears that persons with higher household incomes are more likely to participate in water-based outdoor recreation than those with less income.

With respect to the non-fee versus fee area level of provision, persons included in the $\$ 9,000$ and over range display a slight tendency to use fee areas relatively more than non-fee areas. At the low end of the income distribution ( $1 . e, \$ 8,999$ or less) there is not a single case where fee area users are relatively more predominent than non-fee users. Persons included in the low end of the income distribution display a propensity to use non-fee areas in relatively larger numbers than fee areas.

\section{Type of Employment}

The distribution of non-fee and fee area users with respect to type of occupation is presented in Table XIII. The data reflects a relatively similar distribution of occupations across all lakes. Fort 
TABLE XII

PERCENTAGE DISTRIBUTION OF RECREATIONISTS BY TOTAL HOUSEHOLD INCOME, IN 1974

\begin{tabular}{|c|c|c|c|c|c|c|c|c|c|c|}
\hline Lake & Area & Observations & $\begin{array}{c}\$ 3,000 \\
\text { and } \\
\text { Under }\end{array}$ & $\begin{array}{c}\$ 3,000- \\
4,999\end{array}$ & $\begin{array}{c}\$ 5,000- \\
6,999\end{array}$ & $\begin{array}{c}\$ 7,000- \\
8,999\end{array}$ & $\begin{array}{c}\$ 9,000- \\
11,999\end{array}$ & $\begin{array}{c}\$ 12,000- \\
14,999\end{array}$ & $\begin{array}{c}\$ 15,000- \\
19,999\end{array}$ & $\begin{array}{c}\$ 20,000 \\
\text { and } \\
\text { Over }\end{array}$ \\
\hline Fort Gibson & $\begin{array}{l}\text { Non-fee } \\
\text { Fee } \\
\text { Total }\end{array}$ & $\begin{array}{r}89 \\
89 \\
178\end{array}$ & $\begin{array}{l}3 \\
2 \\
3\end{array}$ & $\begin{array}{l}4 \\
3 \\
4\end{array}$ & $\begin{array}{r}12 \\
6 \\
9\end{array}$ & $\begin{array}{l}13 \\
10 \\
12\end{array}$ & $\begin{array}{l}19 \\
26 \\
22\end{array}$ & $\begin{array}{l}18 \\
28 \\
23\end{array}$ & $\begin{array}{l}19 \\
16 \\
17\end{array}$ & $\begin{array}{r}10 \\
9 \\
10\end{array}$ \\
\hline Eufaula & $\begin{array}{l}\text { Non-fee } \\
\text { Fee } \\
\text { Total }\end{array}$ & $\begin{array}{r}39 \\
78 \\
117\end{array}$ & $\begin{array}{r}10 \\
3 \\
5\end{array}$ & $\begin{array}{r}18 \\
0 \\
6\end{array}$ & $\begin{array}{r}10 \\
4 \\
6\end{array}$ & $\begin{array}{l}8 \\
6 \\
7\end{array}$ & $\begin{array}{l}26 \\
27 \\
27\end{array}$ & $\begin{array}{l}15 \\
19 \\
18\end{array}$ & $\begin{array}{r}8 \\
23 \\
18\end{array}$ & $\begin{array}{r}5 \\
18 \\
14\end{array}$ \\
\hline Tenkiller & $\begin{array}{l}\text { Non-fee } \\
\text { Fee } \\
\text { Total }\end{array}$ & $\begin{array}{l}145 \\
110 \\
255\end{array}$ & $\begin{array}{l}3 \\
2 \\
2\end{array}$ & $\begin{array}{l}1 \\
1 \\
1\end{array}$ & $\begin{array}{l}6 \\
3 \\
4\end{array}$ & $\begin{array}{l}8 \\
5 \\
7\end{array}$ & $\begin{array}{l}17 \\
25 \\
20\end{array}$ & $\begin{array}{l}25 \\
25 \\
25\end{array}$ & $\begin{array}{l}21 \\
24 \\
22\end{array}$ & $\begin{array}{l}19 \\
19 \\
18\end{array}$ \\
\hline
\end{tabular}




\section{TABLE XIII}

PERCENTAGE DISTRIBUTION OF RECREATIONISTS BY TYPE OF EMPLOYMENT, IN 1974

\begin{tabular}{|c|c|c|c|c|c|c|c|c|c|c|}
\hline \multirow[b]{2}{*}{ Lake } & \multirow[b]{2}{*}{ Area } & \multirow[b]{2}{*}{$\begin{array}{l}\text { Obser- } \\
\text { vations }\end{array}$} & \multicolumn{8}{|c|}{ Percent by Type of Employment } \\
\hline & & & $\begin{array}{l}\text { Profes- } \\
\text { sional }\end{array}$ & $\begin{array}{l}\text { Manager; } \\
\text { Adminis- } \\
\text { trator }\end{array}$ & $\begin{array}{c}\text { Sales } \\
\text { Clerical }\end{array}$ & $\begin{array}{l}\text { Crafts - } \\
\text { man }\end{array}$ & $\begin{array}{c}\text { Laborer; } \\
\text { Opera- } \\
\text { tive }\end{array}$ & $\begin{array}{l}\text { Service } \\
\text { Worker }\end{array}$ & Retired & Other* \\
\hline Fort Gibson & $\begin{array}{l}\text { Non-fee } \\
\text { Fee } \\
\text { Total }\end{array}$ & $\begin{array}{r}89 \\
89 \\
178\end{array}$ & $\begin{array}{r}11 \\
8 \\
10\end{array}$ & $\begin{array}{l}11 \\
16 \\
13\end{array}$ & $\begin{array}{l}8 \\
7 \\
7\end{array}$ & $\begin{array}{l}13 \\
11 \\
12\end{array}$ & $\begin{array}{l}19 \\
24 \\
21\end{array}$ & $\begin{array}{l}2 \\
9 \\
6\end{array}$ & $\begin{array}{l}24 \\
16 \\
20\end{array}$ & $\begin{array}{l}10 \\
10 \\
10\end{array}$ \\
\hline Eufaula & $\begin{array}{l}\text { Non-fee } \\
\text { Fee } \\
\text { Total }\end{array}$ & $\begin{array}{r}39 \\
78 \\
117\end{array}$ & $\begin{array}{r}8 \\
10 \\
9\end{array}$ & $\begin{array}{l}13 \\
24 \\
21\end{array}$ & $\begin{array}{l}3 \\
8 \\
6\end{array}$ & $\begin{array}{r}3 \\
12 \\
9\end{array}$ & $\begin{array}{r}8 \\
26 \\
20\end{array}$ & $\begin{array}{r}10 \\
5 \\
7\end{array}$ & $\begin{array}{r}31 \\
6 \\
15\end{array}$ & $\begin{array}{r}26 \\
8 \\
15\end{array}$ \\
\hline Tenkiller & $\begin{array}{l}\text { Non-fee } \\
\text { Fee } \\
\text { Total }\end{array}$ & $\begin{array}{l}145 \\
110 \\
255\end{array}$ & $\begin{array}{l}19 \\
16 \\
18\end{array}$ & $\begin{array}{l}14 \\
18 \\
16\end{array}$ & $\begin{array}{l}15 \\
13 \\
14\end{array}$ & $\begin{array}{r}11 \\
6 \\
9\end{array}$ & $\begin{array}{l}12 \\
19 \\
15\end{array}$ & $\begin{array}{r}8 \\
12 \\
9\end{array}$ & $\begin{array}{r}11 \\
6 \\
9\end{array}$ & $\begin{array}{r}10 \\
9 \\
9\end{array}$ \\
\hline
\end{tabular}

*0ther includes farm workers, housewives, students, not employed, and non-responses where applicable. Lake Fort Gibson had zero non-response. Lake Eufaula had 3 non-responses all from non-fee areas. Lake Tenkiller had zero non-response. 
Gibson is characterized by relatively more retired persons (20\%). Only 15 percent of the Eufaula sample and 9 percent of the Tenkiller sample are retired.

Other categories, which are also related to the higher income classes, which show high participation are professional and manager or administrator. In each case one-fourth of respondents or more are represented by these two categories. As another study concludes, "... discretionary time and income are probably the critical factors" (62, p. $61)$.

\section{Facility Preferences of Recreationists}

As indicated in Chapter I, one of the objectives of this study is to identify the types of facilities desired by recreationists. This section deals specifically with that objective. First recreationists' reasons for selecting a particular site are analyzed. Secondly the types of facilities used by recreationists during the trip on which they were interviewed are identified and analyzed. Third, improvements suggested by recreationists are considered. Finally, those aspects of the facilities which are considered to be problem areas by recreationists are analyzed.

\section{Selection Criteria}

The following question was asked of a11 respondents. "Why did you select this site for your recreation visit?" The results of the question are presented in Table XIV. Note that since many respondents 1 isted more than one reason the totals will sum to more than 100 percent. Visual inspection of the data reveals very similar patterns of 
TABLE XIV

PERCENTAGE OF. DISTRIBUTION OF RECREATIONISTS' REASONS

FOR SELECTING A PARTICULAR LAKE, IN 1974a

\begin{tabular}{|c|c|c|c|c|c|c|c|c|}
\hline \multirow[b]{2}{*}{ Lake } & \multirow[b]{2}{*}{ Area } & \multirow[b]{2}{*}{ Observations } & \multicolumn{6}{|c|}{ Reason } \\
\hline & & & $\begin{array}{l}\text { Close To } \\
\text { Home }\end{array}$ & $\begin{array}{l}\text { Visited This } \\
\text { Area Before }\end{array}$ & $\begin{array}{l}\text { Recommended } \\
\text { By a Friend }\end{array}$ & $\begin{array}{c}\text { Attractive } \\
\text { Area }\end{array}$ & $\begin{array}{l}\text { Specified } \\
\text { Facilitiesb }\end{array}$ & other ${ }^{c}$ \\
\hline Fort Gibson & $\begin{array}{l}\text { Non-fee } \\
\text { Fee } \\
\text { Total }\end{array}$ & $\begin{array}{r}89 \\
89 \\
178\end{array}$ & $\begin{array}{l}26 \\
29 \\
28\end{array}$ & $\begin{array}{l}50 \\
56 \\
53\end{array}$ & $\begin{array}{l}12 \\
16 \\
14\end{array}$ & $\begin{array}{l}36 \\
29 \\
32\end{array}$ & $\begin{array}{l}12 \\
18 \\
15\end{array}$ & $\begin{array}{l}34 \\
30 \\
32\end{array}$ \\
\hline Eufaula & $\begin{array}{l}\text { Non-fee } \\
\text { Fee } \\
\text { Total }\end{array}$ & $\begin{array}{r}39 \\
78 \\
117\end{array}$ & $\begin{array}{l}27 \\
12 \\
17\end{array}$ & $\begin{array}{l}51 \\
42 \\
45\end{array}$ & $\begin{array}{r}12 \\
8 \\
9\end{array}$ & $\begin{array}{l}37 \\
28 \\
31\end{array}$ & $\begin{array}{r}27 \\
7 \\
13\end{array}$ & $\begin{array}{l}32 \\
64 \\
53\end{array}$ \\
\hline Tenkiller & $\begin{array}{l}\text { Non-fee } \\
\text { Fee } \\
\text { Total }\end{array}$ & $\begin{array}{l}145 \\
110 \\
255\end{array}$ & $\begin{array}{l}14 \\
18 \\
15\end{array}$ & $\begin{array}{l}49 \\
54 \\
51\end{array}$ & $\begin{array}{l}26 \\
24 \\
25\end{array}$ & $\begin{array}{l}47 \\
43 \\
46\end{array}$ & $\begin{array}{l}44 \\
60 \\
49\end{array}$ & $\begin{array}{l}30 \\
34 \\
32\end{array}$ \\
\hline
\end{tabular}

${ }^{\text {a }}$ Since many respondents listed more than one reason the percentages sum to more than 100 percent.

${ }^{b}$ Specified facilities includes electric outlets, flush toilets, boat dock or marina, trailer dump station, nearby attractions, and ranger patrolled area.

${ }^{\mathrm{c}}$ Other reasons include, clear water, shade, swim area, good fishing, and many other reasons given only one time. 
response with respect to non-fee area versus fee area users. At Fort Gibson 26 and 29 percent of non-fee and fee area users respectively, chose Fort Gibson simply because it was close to home. This finding is consistent with the earlier one which showed Fort Gibson to be characterized by a large number of users in the shorter travel zones.

The next reason, "visited this area before" was given in nearly half of the cases, across all lakes and by both non-fee and fee area users. This suggests a high propensity of recreationists to make repeat visitation to the various lakes. In fact, another question (not tabulated in the present study) revealed that 90 percent at Fort Gibson, 84 percent at Eufaula and 81 percent at Tenkiller had visited the given lake before.

The responses of Lake Tenkiller recreationists to the next two reasons could also be anticipated. Considering the total sample at each of the three lakes 25 percent of the respondents at Tenkiller chose the lake because it was recommended by a friend. Only 14 percent at Fort Gibson and only 9 percent at Eufaula acted on the recommendation of a friend. Forty-six percent of respondents at Tenkiller chose the site because it was an "attractive area." This compares to slightly more than 30 percent at each of the other two lakes. The very nature of Lake Tenkiller, a scenic, clear water, and beautiful lake, fosters word of mouth advertising and recommendations by one recreationist to another。

A final category of interest reveals just how important various facilities such as electric outlets, flush toilets, and boat docks, are to the recreationists' decision to choose a particular site. Tenkiller users are more concerned with having these facilities than users at the 
other two lakes (Table XIV). In fact, 49 percent, as compared to 15 percent at Fort Gibson and 13 percent at Eufaula, chose Tenkiller because of some specified facilities. Most of that 49 percent is accounted for by the desire for electric hookups and boat ramps (about 10\% each). An additional 10 percent of the Tenkiller recreationists revealed a preference for ranger patrolled areas. A11 these reasons are closely related to the longer term recreation experience which is characteristic of Lake Tenkiller.

Facilities Used

Types of facilities actually used by recreationists are presented in Table XV. Thirteen different specifically identified recreation related facilities were used to some degree by recreationists. Among the most common used facilities were trash barrels, picnic tables, drinking water, and campsites. Remembering that the sample is restricted to those persons who are at least staying overnight, it is interesting to note the propensity to use campsites. Somewhere between 5 and 21 percent of campers are not using established campsites depending on the lake and whether or not the area being used is a fee area or a non-fee area. At Fort Gibson Lake for example 21 percent of the non-fee recreation groups are camping in some area other than the designated campsites. This compares to 5 percent at Eufaula and 10 percent at Tenkiller. The fee area counterparts in this same category are 16 percent at Fort Gibson (sti1l the 1argest), 9 percent at Eufaula, and 7 percent at Tenkiller. The question of interest here is whether or not groups are not using designated campsites because they were all occupied. Unfortunately the available data does not answer this question. 
TABLE XV

PERCENTAGE DISTRIBUTION OF TYPES OF FACILITIES

USED BY RECREATIONISTS, IN 1974ª

\begin{tabular}{|c|c|c|c|c|c|c|c|c|c|}
\hline \multirow[b]{2}{*}{ Lake } & \multirow[b]{2}{*}{ Area } & \multirow[b]{2}{*}{ Observations } & \multicolumn{7}{|c|}{ Facilities } \\
\hline & & & $\begin{array}{l}\text { Picnic } \\
\text { Table }\end{array}$ & Gri11 & $\begin{array}{l}\text { Picnic } \\
\text { Shelter }\end{array}$ & $\begin{array}{l}\text { Trash } \\
\text { Barrel }\end{array}$ & Toilet & Shower & Campsite \\
\hline Fort Gibson & $\begin{array}{l}\text { Non-fee } \\
\text { Fee } \\
\text { Total }\end{array}$ & $\begin{array}{r}89 \\
89 \\
178\end{array}$ & $\begin{array}{l}88 \\
95 \\
91\end{array}$ & $\begin{array}{l}36 \\
48 \\
42\end{array}$ & $\begin{array}{l}2 \\
8 \\
5\end{array}$ & $\begin{array}{l}92 \\
96 \\
94\end{array}$ & $\begin{array}{l}79 \\
71 \\
75\end{array}$ & $\begin{array}{l}23 \\
34 \\
28\end{array}$ & $\begin{array}{l}79 \\
84 \\
82\end{array}$ \\
\hline Eufaula & $\begin{array}{l}\text { Non-fee } \\
\text { Fee } \\
\text { Total }\end{array}$ & $\begin{array}{r}39 \\
78 \\
117\end{array}$ & $\begin{array}{l}98 \\
89 \\
91\end{array}$ & $\begin{array}{l}46 \\
57 \\
53\end{array}$ & $\begin{array}{l}5 \\
0 \\
2\end{array}$ & $\begin{array}{l}95 \\
94 \\
95\end{array}$ & $\begin{array}{l}93 \\
93 \\
93\end{array}$ & $\begin{array}{l}39 \\
66 \\
57\end{array}$ & $\begin{array}{l}95 \\
91 \\
92\end{array}$ \\
\hline Tenkiller & $\begin{array}{l}\text { Non-fee } \\
\text { Fee } \\
\text { Total }\end{array}$ & $\begin{array}{l}145 \\
110 \\
255\end{array}$ & $\begin{array}{l}90 \\
91 \\
90\end{array}$ & $\begin{array}{l}47 \\
47 \\
47\end{array}$ & $\begin{array}{l}4 \\
3 \\
4\end{array}$ & $\begin{array}{l}95 \\
99 \\
96\end{array}$ & $\begin{array}{l}82 \\
91 \\
86\end{array}$ & $\begin{array}{l}22 \\
53 \\
32\end{array}$ & $\begin{array}{l}90 \\
93 \\
91\end{array}$ \\
\hline
\end{tabular}

${ }^{\mathrm{a}}$ Since many respondents listed more than one reason the percentages sum to more than 100 percent. 
TABLE XV (Continued)

\begin{tabular}{|c|c|c|c|c|c|c|c|c|c|}
\hline \multirow[b]{2}{*}{ Lake } & \multirow[b]{2}{*}{ Area } & \multirow[b]{2}{*}{ Observations } & \multicolumn{6}{|c|}{ Facilities } & \multirow[b]{2}{*}{ Other } \\
\hline & & & $\begin{array}{l}\text { Boat } \\
\text { Ramp }\end{array}$ & $\begin{array}{l}\text { Nature } \\
\text { Trail }\end{array}$ & $\begin{array}{l}\text { Drinking } \\
\text { Water }\end{array}$ & $\begin{array}{l}\text { Electric } \\
\text { Hookups }\end{array}$ & $\begin{array}{l}\text { Dump } \\
\text { Station }\end{array}$ & Playground & \\
\hline Fort Gibson & $\begin{array}{l}\text { Non-fee } \\
\text { Fee } \\
\text { Total }\end{array}$ & $\begin{array}{r}89 \\
89 \\
178\end{array}$ & $\begin{array}{l}35 \\
47 \\
40\end{array}$ & $\begin{array}{l}2 \\
2 \\
2\end{array}$ & $\begin{array}{l}80 \\
73 \\
76\end{array}$ & $\begin{array}{l}34 \\
36 \\
35\end{array}$ & $\begin{array}{r}8 \\
15 \\
11\end{array}$ & $\begin{array}{l}5 \\
1 \\
3\end{array}$ & $\begin{array}{l}3 \\
2 \\
3\end{array}$ \\
\hline Eufaula & $\begin{array}{l}\text { Non-fee } \\
\text { Fee } \\
\text { Total }\end{array}$ & $\begin{array}{r}39 \\
78 \\
117\end{array}$ & $\begin{array}{l}37 \\
66 \\
57\end{array}$ & $\begin{array}{l}5 \\
3 \\
4\end{array}$ & $\begin{array}{l}83 \\
77 \\
79\end{array}$ & $\begin{array}{r}22 \\
2 \\
9\end{array}$ & $\begin{array}{r}12 \\
9 \\
10\end{array}$ & $\begin{array}{r}24 \\
2 \\
9\end{array}$ & $\begin{array}{l}7 \\
5 \\
5\end{array}$ \\
\hline Tenkiller & $\begin{array}{l}\text { Non-fee } \\
\text { Fee } \\
\text { Total }\end{array}$ & $\begin{array}{l}145 \\
110 \\
255\end{array}$ & $\begin{array}{l}49 \\
62 \\
53\end{array}$ & $\begin{array}{l}5 \\
7 \\
6\end{array}$ & $\begin{array}{l}82 \\
92 \\
85\end{array}$ & $\begin{array}{l}36 \\
44 \\
39\end{array}$ & $\begin{array}{l}18 \\
19 \\
18\end{array}$ & $\begin{array}{l}4 \\
2 \\
3\end{array}$ & $\begin{array}{l}4 \\
8 \\
5\end{array}$ \\
\hline
\end{tabular}


One category where there is an apparent difference between fee and non-fee users is boat ramp use. At Fort Gibson 47 percent of fee area respondents used a boat ramp compared to only 35 percent of their nonfee counterparts. The same figures for Eufaula are 66 and 37 percent respectively and for Tenkiller they are 62 and 49 percent respectively.

\section{Improvements}

Each recreation group was asked what improvements they would like to see made to the recreation site which they were using. The results of the question are presented in Table XVI. At most, 20 percent of the recreationists were satisfied with existing sites. This largest indication of satisfaction occurred at Fort Gibson where 20 and 19 percent of non-fee and fee area users, respectively, offered no suggestions for improvement. The corresponding figures for Eufaula are 15 and 9 percent, or about 11 percent overa 11. For Lake Tenkiller 11 and 14 percent respectively offered no suggestions.

One frequent suggestion related to installation of flush type toilets. The desire for this improvement is undoubtedly related to the odor and unsanitary conditions associated with the old pit type toilets. The public use areas at Fort Gibson and Tenkiller Lakes typically have more of the old type structures and were therefore more likely to be cited for this improvement. Most of the new facilities (and replacement facilities) are of the flush type, and continued improvement in this area is expected.

Another highly desired improvement was electric outlets. In fee areas and non-fee areas alike, approximately one-third of recreationists interviewed cited electric outlets (or more electric outlets) as a 
TABLE XVI

PERCENTAGE DISTRIBUTION OF RECREATIONISTS: SUGGESTIONS

FOR SITE IMPROVEMENTS, IN $1974^{\mathrm{a}}$

\begin{tabular}{|c|c|c|c|c|c|c|c|c|}
\hline \multirow[b]{2}{*}{ Lake } & \multirow[b]{2}{*}{ Area } & \multirow[b]{2}{*}{ Observations } & \multicolumn{6}{|c|}{ Improvements } \\
\hline & & & $\begin{array}{l}\text { More } \\
\text { Boat } \\
\text { Ramps }\end{array}$ & $\begin{array}{l}\text { More } \\
\text { Camp } \\
\text { Sites }\end{array}$ & $\begin{array}{c}\text { More } \\
\text { Swimming } \\
\text { Areas }\end{array}$ & $\begin{array}{c}\text { Improve } \\
\text { Fish } \\
\text { Management }\end{array}$ & $\begin{array}{c}\text { More } \\
\text { Access } \\
\text { Roads }\end{array}$ & $\begin{array}{l}\text { Flush } \\
\text { Toilets }\end{array}$ \\
\hline Fort Gibson & $\begin{array}{l}\text { Non-fee } \\
\text { Fee } \\
\text { Total }\end{array}$ & $\begin{array}{r}89 \\
89 \\
178\end{array}$ & $\begin{array}{l}1 \\
6 \\
4\end{array}$ & $\begin{array}{r}10 \\
6 \\
8\end{array}$ & $\begin{array}{l}13 \\
15 \\
14\end{array}$ & $\begin{array}{l}17 \\
14 \\
16\end{array}$ & $\begin{array}{l}0 \\
1 \\
1\end{array}$ & $\begin{array}{l}37 \\
24 \\
27\end{array}$ \\
\hline Eufaula & $\begin{array}{l}\text { Non-fee } \\
\text { Fee } \\
\text { Total }\end{array}$ & $\begin{array}{r}39 \\
78 \\
117\end{array}$ & $\begin{array}{l}5 \\
2 \\
3\end{array}$ & $\begin{array}{l}5 \\
5 \\
5\end{array}$ & $\begin{array}{r}17 \\
8 \\
11\end{array}$ & $\begin{array}{r}17 \\
5 \\
9\end{array}$ & $\begin{array}{l}0 \\
0 \\
0\end{array}$ & $\begin{array}{l}20 \\
25 \\
23\end{array}$ \\
\hline Tenkiller & $\begin{array}{l}\text { Non-fee } \\
\text { Fee } \\
\text { Total }\end{array}$ & $\begin{array}{l}145 \\
110 \\
255\end{array}$ & $\begin{array}{r}8 \\
10 \\
8\end{array}$ & $\begin{array}{l}16 \\
15 \\
10\end{array}$ & $\begin{array}{l}15 \\
10 \\
13\end{array}$ & $\begin{array}{l}12 \\
11 \\
12\end{array}$ & $\begin{array}{l}4 \\
1 \\
3\end{array}$ & $\begin{array}{l}40 \\
25 \\
36\end{array}$ \\
\hline
\end{tabular}

a Since many respondents listed more than one reason the percentages sum to more than 100 percent. 
TABLE XVI (Continued)

\begin{tabular}{|c|c|c|c|c|c|c|c|c|}
\hline \multirow[b]{2}{*}{ Lake } & \multirow[b]{2}{*}{ Area } & \multirow[b]{2}{*}{ Observations } & \multicolumn{6}{|c|}{ Improvements } \\
\hline & & & Showers & $\begin{array}{l}\text { Dump } \\
\text { Station }\end{array}$ & $\begin{array}{l}\text { Pull } \\
\text { Through } \\
\text { Sites }\end{array}$ & $\begin{array}{l}\text { Electric } \\
\text { Outlets }\end{array}$ & Other & None \\
\hline Fort Gibson & $\begin{array}{l}\text { Non-fee } \\
\text { Fee } \\
\text { Total }\end{array}$ & $\begin{array}{r}89 \\
89 \\
178\end{array}$ & $\begin{array}{l}34 \\
28 \\
31\end{array}$ & $\begin{array}{l}2 \\
3 \\
3\end{array}$ & $\begin{array}{l}2 \\
0 \\
1\end{array}$ & $\begin{array}{l}30 \\
31 \\
30\end{array}$ & $\begin{array}{l}38 \\
40 \\
39\end{array}$ & $\begin{array}{l}20 \\
19 \\
20\end{array}$ \\
\hline Eufaula & $\begin{array}{l}\text { Non-fee } \\
\text { Fee } \\
\text { Total }\end{array}$ & $\begin{array}{r}39 \\
78 \\
117\end{array}$ & $\begin{array}{l}29 \\
20 \\
23\end{array}$ & $\begin{array}{l}5 \\
1 \\
2\end{array}$ & $\begin{array}{l}0 \\
0 \\
0\end{array}$ & $\begin{array}{l}24 \\
52 \\
43\end{array}$ & $\begin{array}{l}44 \\
48 \\
47\end{array}$ & $\begin{array}{r}15 \\
9 \\
11\end{array}$ \\
\hline Tenkiller & $\begin{array}{l}\text { Non-fee } \\
\text { Fee } \\
\text { Total }\end{array}$ & $\begin{array}{l}145 \\
110 \\
255\end{array}$ & $\begin{array}{l}49 \\
37 \\
45\end{array}$ & $\begin{array}{l}3 \\
3 \\
3\end{array}$ & $\begin{array}{l}1 \\
1 \\
1\end{array}$ & $\begin{array}{l}27 \\
26 \\
27\end{array}$ & $\begin{array}{l}36 \\
36 \\
36\end{array}$ & $\begin{array}{l}11 \\
14 \\
12\end{array}$ \\
\hline
\end{tabular}


desired improvement. This finding reflects the growing notion that outdoor recreation is no longer a return to the wilderness experience. It appears that people want to maintain some degree of attachment to the so called "creature comforts." As one study revealed, "... the urbanite leaving the city is trying to leave only the discomforts of city life, not necessarily the comforts" (30, p. 97).

\section{Problems}

Various problems which were cited by recreationists are presented in Table XVII. The distribution reflects recreationists' response to which of these problems are the most important to them. Thirty-seven, 36, and 32 percent, respectively, at Fort Gibson, Eufaula, and Tenkiller reported no problems at the lake. Of those specified categories remaining, majority rule suggests that dirty toilets and noise problems due to land vehicles are the problems of most concern to recreationists. The toilet problem was discussed previously, but the noise problem requires further inquiry. This problem appears to have some special significance for the empirical dichotomy. At each lake fee area users are significantly more concerned over the problem than the non-fee area counterparts. This tendency, although in the same direction is not as pronounced at Tenkiller. The reasons for the relatively greater concern over the noise problem in the fee areas, without more information, can only be conjecture. One reason may be that because people pay fees they expect quieter areas. This is the type of problem that can have important implications for site management decisions.

The next highest ranking problem identified by the recreationists was insufficient security patrol. On average about 9 percent of al1 
TABLE XVII

PERCENTAGE DISTRIBUTION OF MOST IMPORTANT PROBLEM CITED BY RECREATIONISTS, IN 1974

\begin{tabular}{|c|c|c|c|c|c|c|c|}
\hline \multirow[b]{2}{*}{ Lake } & \multirow[b]{2}{*}{ Area } & \multirow[b]{2}{*}{ Observations } & \multicolumn{5}{|c|}{ Problems } \\
\hline & & & Littering & $\begin{array}{c}\text { Trash } \\
\text { Collection }\end{array}$ & $\begin{array}{l}\text { Dirty } \\
\text { Toilets }\end{array}$ & $\begin{array}{c}\text { Maintenance } \\
\text { of Grass }\end{array}$ & $\begin{array}{l}\text { Noise } \\
\text { Problems }\end{array}$ \\
\hline Fort Gibson & $\begin{array}{l}\text { Non-fee } \\
\text { Fee } \\
\text { Total }\end{array}$ & $\begin{array}{r}89 \\
89 \\
178\end{array}$ & $\begin{array}{l}6 \\
6 \\
6\end{array}$ & $\begin{array}{l}3 \\
0 \\
2\end{array}$ & $\begin{array}{l}11 \\
11 \\
11\end{array}$ & $\begin{array}{l}2 \\
2 \\
2\end{array}$ & $\begin{array}{l}10 \\
20 \\
15\end{array}$ \\
\hline Eufaula & $\begin{array}{l}\text { Non-fee } \\
\text { Fee } \\
\text { Total }\end{array}$ & $\begin{array}{r}39 \\
78 \\
117\end{array}$ & $\begin{array}{r}15 \\
8 \\
10\end{array}$ & $\begin{array}{l}0 \\
1 \\
1\end{array}$ & $\begin{array}{r}3 \\
16 \\
12\end{array}$ & $\begin{array}{l}3 \\
2 \\
2\end{array}$ & $\begin{array}{r}5 \\
15 \\
12\end{array}$ \\
\hline Tenkiller & $\begin{array}{l}\text { Non-fee } \\
\text { Fee } \\
\text { Total }\end{array}$ & $\begin{array}{l}145 \\
110 \\
255\end{array}$ & $\begin{array}{l}7 \\
3 \\
6\end{array}$ & $\begin{array}{l}2 \\
0 \\
1\end{array}$ & $\begin{array}{r}14 \\
9 \\
12\end{array}$ & $\begin{array}{l}5 \\
2 \\
4\end{array}$ & $\begin{array}{l}11 \\
13 \\
12\end{array}$ \\
\hline
\end{tabular}


TABLE XVII (Continued)

\begin{tabular}{|c|c|c|c|c|c|c|c|}
\hline \multirow[b]{2}{*}{ Lake } & \multirow[b]{2}{*}{ Area } & \multirow[b]{2}{*}{ Observations } & \multicolumn{5}{|c|}{ Problems } \\
\hline & & & $\begin{array}{l}\text { Safety } \\
\text { Problems }\end{array}$ & $\begin{array}{l}\text { Road } \\
\text { Dust }\end{array}$ & $\begin{array}{c}\text { Security } \\
\text { Patrol }\end{array}$ & Other & None \\
\hline Fort Gibson & $\begin{array}{l}\text { Non-fee } \\
\text { Fee } \\
\text { Total }\end{array}$ & $\begin{array}{r}89 \\
89 \\
178\end{array}$ & $\begin{array}{r}9 \\
12 \\
10\end{array}$ & $\begin{array}{l}3 \\
0 \\
2\end{array}$ & $\begin{array}{r}6 \\
11 \\
8\end{array}$ & $\begin{array}{r}12 \\
5 \\
9\end{array}$ & $\begin{array}{l}40 \\
34 \\
37\end{array}$ \\
\hline Eufaula & $\begin{array}{l}\text { Non-fee } \\
\text { Fee } \\
\text { Total }\end{array}$ & $\begin{array}{r}39 \\
78 \\
117\end{array}$ & $\begin{array}{l}0 \\
1 \\
1\end{array}$ & $\begin{array}{r}10 \\
1 \\
4\end{array}$ & $\begin{array}{r}21 \\
5 \\
10\end{array}$ & $\begin{array}{l}13 \\
13 \\
13\end{array}$ & $\begin{array}{l}31 \\
38 \\
36\end{array}$ \\
\hline Tenkiller & $\begin{array}{l}\text { Non-fee } \\
\text { Fee } \\
\text { Total }\end{array}$ & $\begin{array}{l}145 \\
110 \\
255\end{array}$ & $\begin{array}{l}7 \\
3 \\
6\end{array}$ & $\begin{array}{l}1 \\
3 \\
2\end{array}$ & $\begin{array}{l}9 \\
9 \\
9\end{array}$ & $\begin{array}{l}14 \\
20 \\
16\end{array}$ & $\begin{array}{l}29 \\
37 \\
32\end{array}$ \\
\hline
\end{tabular}


respondents indicated that lack of security patrols was a major problem.

Analyzing these problems at the individual lake level reveals slightly different rankings than those so far indicated. This finding in itself is indicative of the problem of "good" outdoor recreation management. A "good" policy at one lake may not be as "good" at another.

\section{Expenditure Patterns}

The expenditure patterns reported in this section are based on "out of pocket" costs of the recreationists. Included in these costs are lodging expenditures, food and beverage expenditures, transportation expenditures (to and from the area), recreation related expenditures, and other miscellaneous expenditures. Not included in the costs are the values of recreational equipment. An appropriate estimate of this value would require amortization over the life of the equipment and allocation of the value only to that use of the equipment at a given lake. This task is beyond the scope of the present study.

Expenditures are reported in Table XVIII in terms of expenditures per visitor day. This means that each figure reported in the Table represents the average expenditure of one person at a given lake for one day. Total expenditures range from approximately $\$ 5.49$ at Fort Gibson non-fee areas to \$7.32 at Eufaula fee areas. Lake Tenkiller is the only lake where total average expenditures are greater for non-fee area users than for fee area users. In each case food and beverages is the largest "out of pocket" expenditure, ranging from $\$ 3.12$ per person per day at Fort Gibson fee areas to $\$ 4.42$ at Tenkiller non-fee areas. The next largest "out of pocket" cost is transportation. Transportation 
TABLE XVIII

AVERAGE TRIP EXPENDITURE PER VISITOR DAY, BY LAKE, IN 1974

\begin{tabular}{|c|c|c|c|c|c|c|c|}
\hline \multirow[b]{2}{*}{ Lake } & \multirow[b]{2}{*}{ Area } & \multicolumn{6}{|c|}{ Expenditure Category } \\
\hline & & Lodging & $\begin{array}{l}\text { Food and } \\
\text { Beverages }\end{array}$ & Transportation & Recreation & Other & Total \\
\hline Fort Gibson & $\begin{array}{l}\text { Non-fee } \\
\text { Fee } \\
\text { Total }\end{array}$ & $\begin{array}{l}.32 \\
.50 \\
.41\end{array}$ & $\begin{array}{l}3.61 \\
3.12 \\
3.36\end{array}$ & $\begin{array}{l}1.07 \\
1.51 \\
1.29\end{array}$ & $\begin{array}{l}.32 \\
.40 \\
.36\end{array}$ & $\begin{array}{l}.17 \\
.10 \\
.13\end{array}$ & $\begin{array}{l}5.49 \\
5.63 \\
5.55\end{array}$ \\
\hline Eufaula & $\begin{array}{l}\text { Non-fee } \\
\text { Fee } \\
\text { Total }\end{array}$ & $\begin{array}{l}.07 \\
.65 \\
.46\end{array}$ & $\begin{array}{l}3.35 \\
4.13 \\
3.88\end{array}$ & $\begin{array}{l}1.89 \\
1.53 \\
1.64\end{array}$ & $\begin{array}{l}.40 \\
.89 \\
.73\end{array}$ & $\begin{array}{l}.13 \\
.12 \\
.12\end{array}$ & $\begin{array}{l}5.84 \\
7.32 \\
6.83\end{array}$ \\
\hline Tenkiller & $\begin{array}{l}\text { Non-fee } \\
\text { Fee } \\
\text { Total }\end{array}$ & $\begin{array}{l}.26 \\
.59 \\
.40\end{array}$ & $\begin{array}{l}4.42 \\
3.50 \\
4.03\end{array}$ & $\begin{array}{l}1.42 \\
1.33 \\
1.38\end{array}$ & $\begin{array}{l}.60 \\
.60 \\
.60\end{array}$ & $\begin{array}{l}.10 \\
.09 \\
.10\end{array}$ & $\begin{array}{l}6.80 \\
6.11 \\
6.51\end{array}$ \\
\hline
\end{tabular}


costs range from $\$ 1.07$ to $\$ 1.89$.

Average visitor days for Fort Gibson, Eufaula and Tenkiller are summarized in Table XIX. These data can be used to estimate average expenditures per trip. At Lake Eufaula for example, non-fee area users average 19.02 visitor days per trip. Multiplying this by the average expenditure of $\$ 5.84$ per visitor day of non-fee area users yields a total expenditure per visit for an average group of $\$ 111.07$. The same computation for the fee area users yields $\$ 131.02$. Fee area users at Eufaula spend on the average \$19.95 more than their non-fee area counterparts. Similar computations for Tenkiller and Fort Gibson reveals that non-fee area users outspend their fee area counterparts by approximately $\$ 30.00$ per trip at Fort Gibson while fee area users spend $\$ 4.33$ per trüp more at Tenky̆ller.

TABLE XIX

AVERAGE VISITOR DAYS PER TRIP, BY LAKE, IN 1974

\begin{tabular}{lccc}
\hline & \multicolumn{3}{c}{ Average Visitor Days } \\
\cline { 2 - 4 } Area & Fort Gibson & Eufaula & Tenki17er \\
\hline Non-fee & 20.87 & 19.02 & 25.50 \\
Fee & 14.94 & 17.90 & 29.09 \\
Tota1 & 17.89 & 18.26 & 27.06 \\
\hline
\end{tabular}


A slightly different view of recreationists' expenditure patterns is given by considering what part of each dollar is allocated to each of the previously mentioned expenditure categories. Figures 4 through 6 display typical dollar expenditures for each class of user for each of the lakes.

Figure 4, for example, indicates that $\$ .66$ out of every non-fee area user's dollar at Fort Gibson is spent on food and beverages. This compares to $\$ .55$ cents for the fee area group. In fact, relatively more of a given dollar spent by non-fee area users, across all lakes, is spent on food and beverages than for the fee area counterparts (see Figures 4, 5, and 6). On the other hand, the trend is reversed for lodging expenditures (which includes payment of fees) as fee area users always spend relatively more for lodging than the non-fee group. Whether or not the fee area users economize on food to be able to enjoy some given characteristic of a fee area cannot be concluded from the data available, but the trend can be identified and its consistency noted。

As previously concluded transportation is the second largest "out of pocket" cost to the recreationist. It ranges from about 20 to 30 cents out of each dollar spent, depending on lake and user classification. These two largest expenditures account for $83.8,80.8$ and 83.7 cents, respectively, out of every dollar spent by recreationists at Fort Gibson, Eufaula, and Tenkiller. The portion of each dollar remaining (approximately 16 to 19 cents) is spent on recreation related activities and other expenditures not included in the four specified categories. 


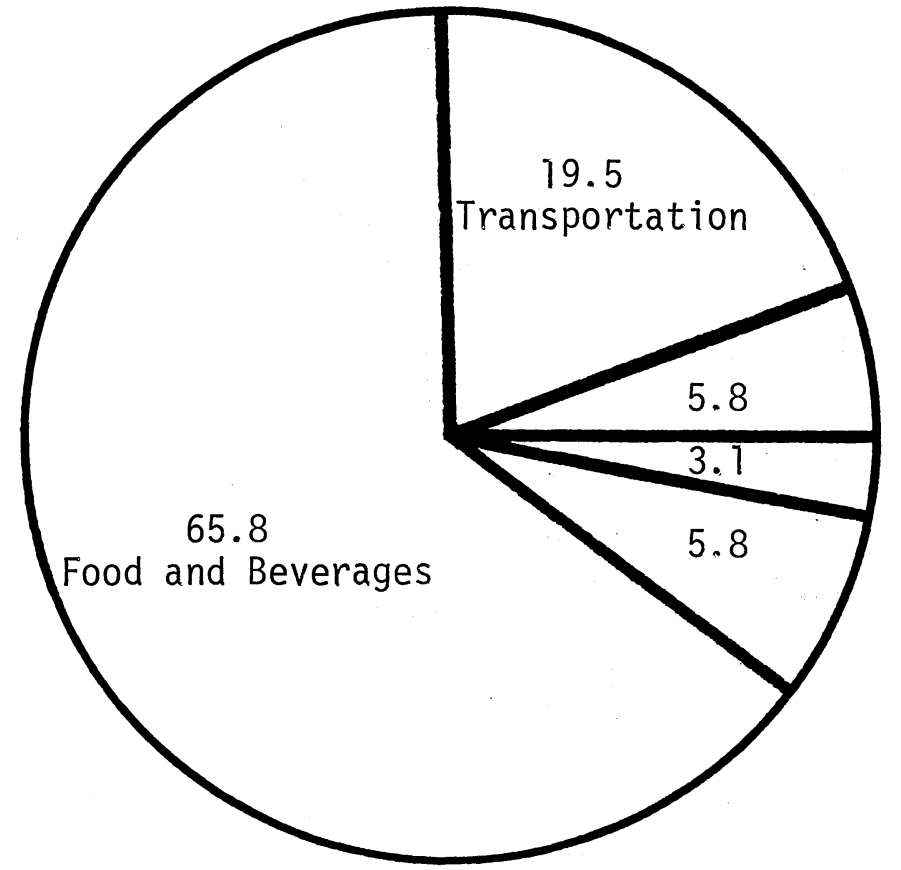

Non-fee Area Users

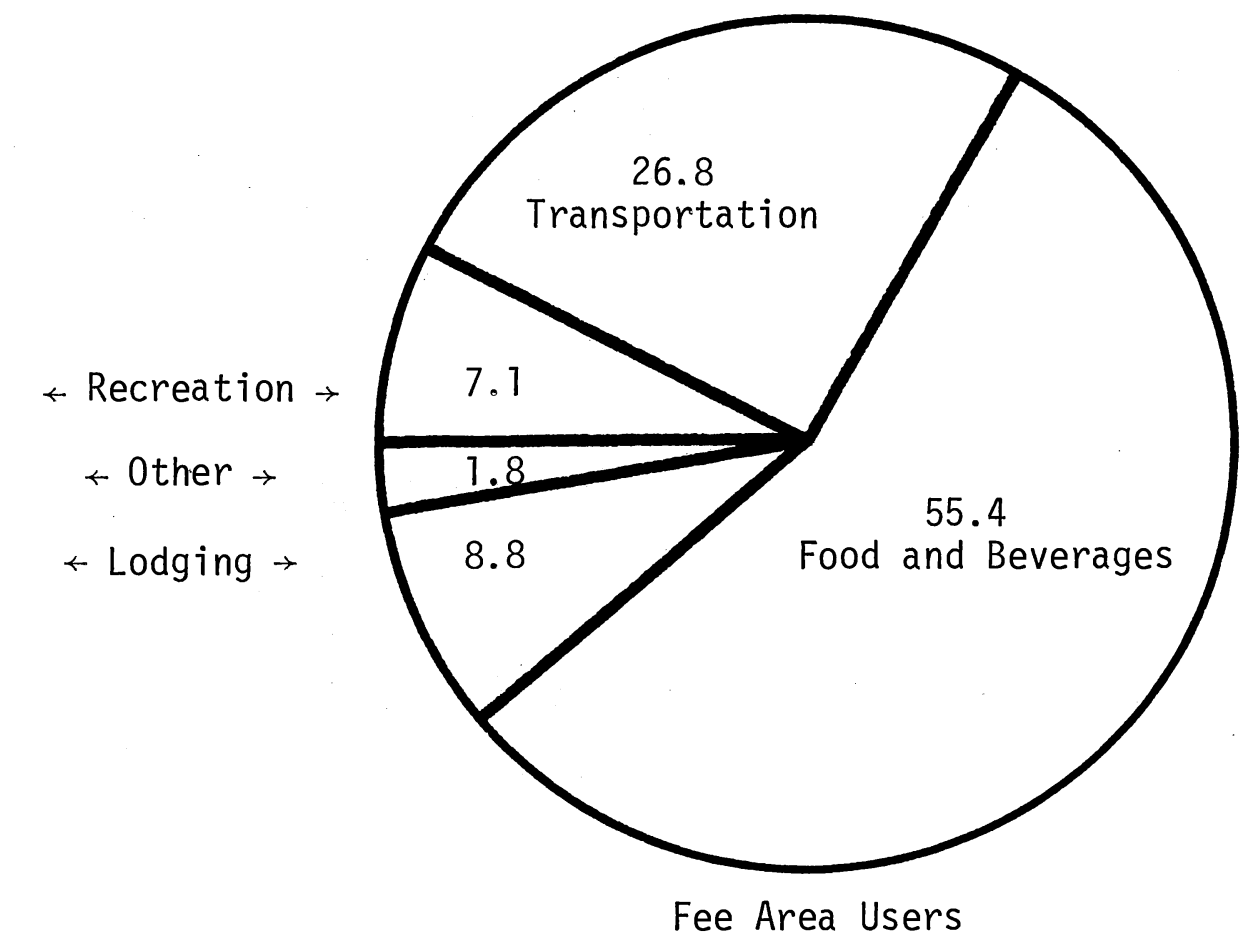

Figure 4. Typical Dollar Expenditures, Lake Fort Gibson, In 1974 


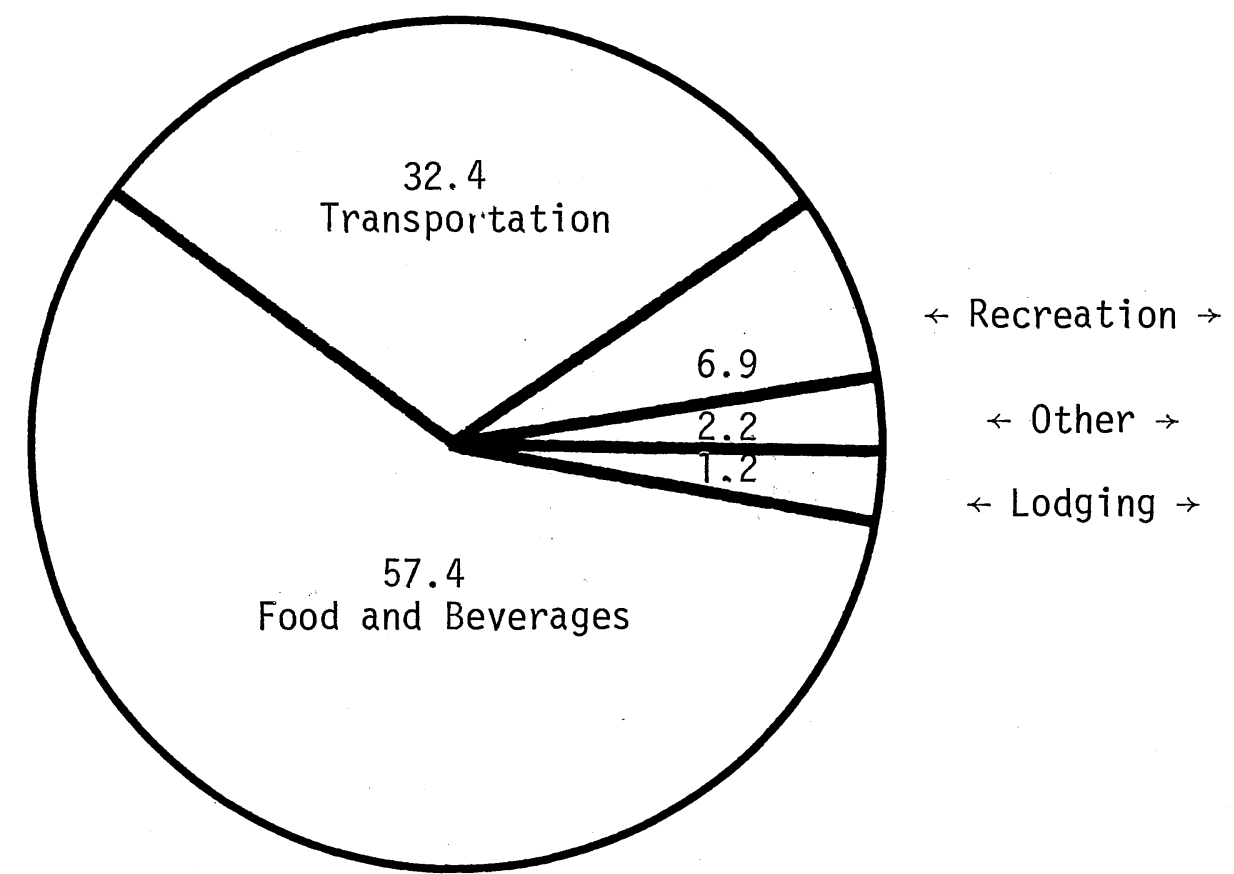

Non-fee Area Users

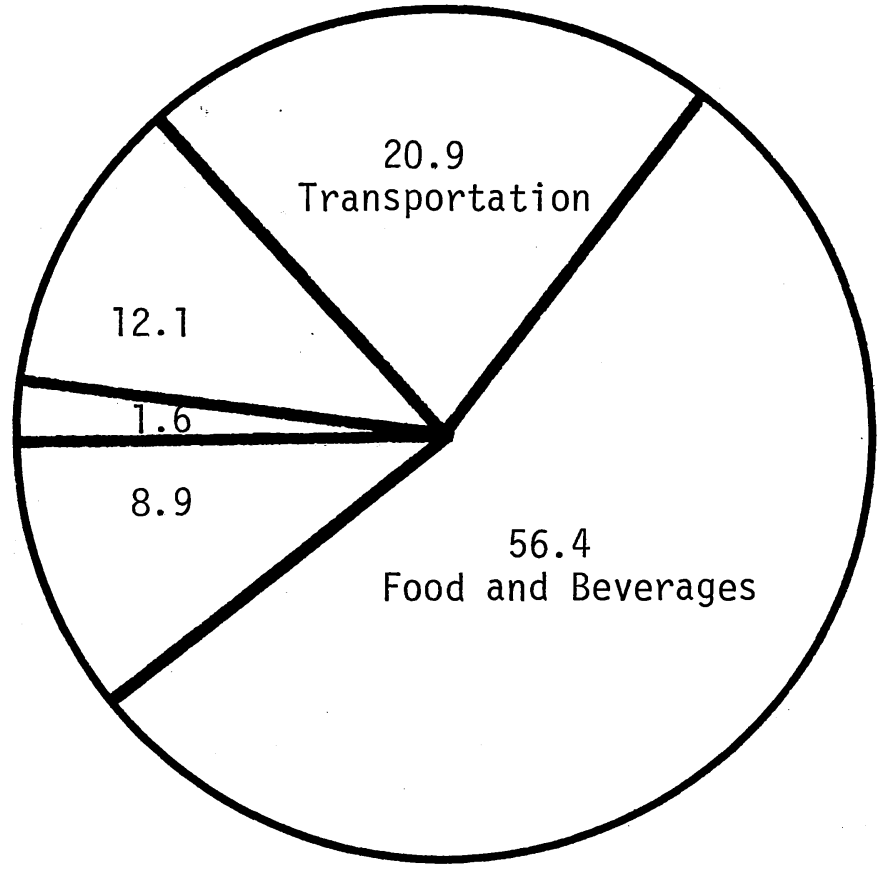

Fee Area Users

Figure 5. Typical Dollar Expenditures, Lake Eufaula, In 1974 


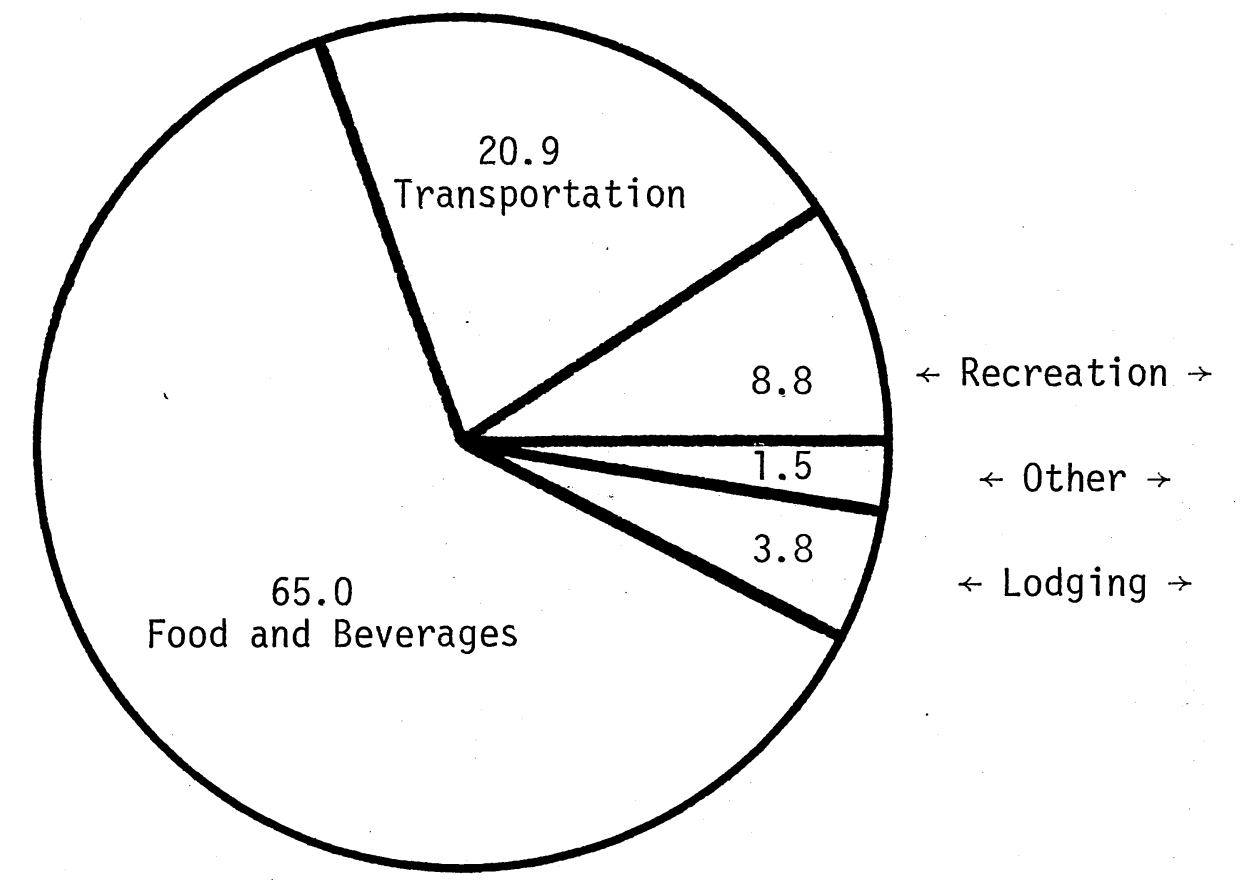

Non-fee Area Users

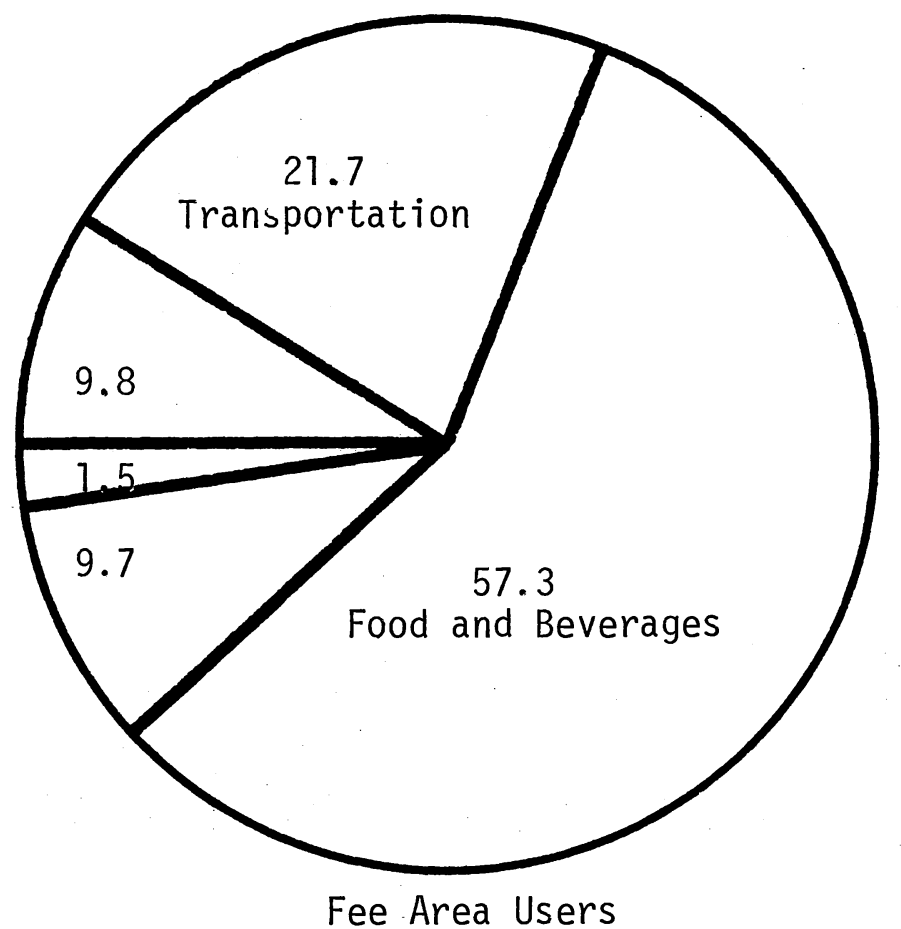

Fee Area Users

Figure 6. Typical Dollar Expenditures, Lake Tenkiller, In 1974 
Summary

This chapter has analyzed various data related to water-based outdoor recreation. Relatively greater numbers of visits were found to originate in those travel zones containing a major city. The length of stay for a recreation trip was found to be very similar across all classifications. The largest percentage of fee area users occurs in the 30 to 49 years of age range, with younger and older persons preferring the non-fee areas. Level of education did not seem to be significantly different across lakes or users. With respect to income, there did seem to be a slight tendency for fee area users to be in the higher income categories. The type of employment variable reflected similar distributions across a 11 lakes. The highest participation rates for working recreationists came from the labor-operative, professional, and manager-administrator employment categories.

The section on facility use and preferences suggests that recreationists may not particularly want to "rough it" when engaging in waterbased outdoor recreation. Inherent in the discussion of facility use and preference are numerous implications related to management of waterbased outdoor recreation facilities. These policy implications will be discussed in a later chapter. For the most part facility use and preferences were similar by user classification. The differences that occurred were more likely to be between lakes rather than between different types of users.

The analysis of expenditures revealed that expenditures per visitor day are normally greater by fee area users. But, non-fee area users may be economizing on expenditure per visitor day by spreading total expenditures over a longer trip. In the typical dollar analysis it was 
found that approximately $\$ .60$ out of every recreationist's dollar is spent on food and beverages, $\$ .20$ on transportation, and the remaining $\$ .20$ is distributed between recreation related expenditures, lodging expenditures, and other miscellaneous expenses.

This section has, in general, described an average recreation group at each of the recreation sites. The preferences of this average group are most likely influenced by age, education, and other socioeconomic variables. These variables affect decisions at the group level of behavior. Likewise, the decision to use a particular type of facility at any given lake is a group behavioral decision. Similarly the decision to spend money on water-based outdoor recreation is a group action. Hence it seems only natural to approach the question of demand from the point of view of a recreation group. This is the task of the next chapter. 


\section{CHAPTER $V$}

\section{EMPIRICAL ESTIMATION OF DEMAND}

The theory of consumer behavior and demand rests on the premise that a consumer or consumer group attempts to allocate a limited money income among various goods and services such that his satisfaction is maximized $(21, p .35)$. In the case of water-based outdoor recreation each recreation group evaluates the expected satisfaction in relation to costs, limited by financial resources. Chapter III developed a theoretical and an empirical model which reflects these relationships. It is the task of the following sections to apply the empirical model to the data collected from each of the three lakes, and to test the hypotheses stated in Chapter I.

\section{Recreation Demand Curves: Lake Tenkiller}

The regression coefficients for equation (11) are presented in Table XX for each of the two samples; non-fee and fee area users at Lake Tenkiller. The coefficients have plausible signs; the coefficient of determination $\left(R^{2}\right)$ is higher for fee area users $(.32)$ than for nonfee users $(.20)$ and is comparable in general to similar studies. A test of the null hypothesis that the demand model has no power for explaining variations in visitor days is rejected at the one percent level. ${ }^{1}$

${ }^{1}$ The calculated value of the F statistic for non-fee and fee area users with 6 and 142 degrees of freedom and 6 and 108 degrees of freedom, respectively, are 5.58 and 7.98 at the 1 percent 1 evel. 
TABLE XX
REGRESSION COEFFICIENTS AND t-VALUES FOR WATER-BASED OUTDOOR RECREATION DEMAND MODEL: LAKE TENKILLER

\begin{tabular}{|c|c|c|c|c|}
\hline \multirow{3}{*}{$\begin{array}{c}\text { Independent } \\
\text { Variables }\end{array}$} & \multicolumn{4}{|c|}{ Sample } \\
\hline & \multicolumn{2}{|c|}{ Non-fee Area } & \multicolumn{2}{|c|}{ Fee Area } \\
\hline & Coefficient & t-value & Coefficient & $t$-value \\
\hline Constant & 3.273 & $9.992 * *$ & 3.521 & $10.295 * *$ \\
\hline$P_{1}$ & -0.633 & $-5.717 * *$ & -0.817 & $-6.025 * *$ \\
\hline$P_{2}$ & 0.074 & 0.354 & 0.076 & 0.386 \\
\hline$P_{3}$ & 0.122 & 0.694 & 0.246 & 1.568 \\
\hline$D_{4}$ & -0.095 & -0.432 & -0.432 & -1.579 \\
\hline$D_{5}$ & 0.122 & 0.544 & -0.499 & $-2.447^{*}$ \\
\hline$D_{6}$ & -0.025 & -0.132 & -0.395 & $-2.007 *$ \\
\hline$R^{2}$ & .20 & & .32 & \\
\hline
\end{tabular}

** Significant at the 1 percent level.

* Significant at the 5 percent level. 
The coefficients of own price are negative and highly significant for both samples. Therefore, hypothes is (1) which states that quantity demanded and own price are negatively related, cannot be rejected. The non-fee area coefficient indicates that a one percent increase in price will reduce quantity $(R)$ by 0.63 percent. Similarly for the fee area sample, a one percent increase in price will decrease quantity ( $R$ ) by 0.82 percent. Both of these estimates correspond to a relatively inelastic demand curve and assume the relative position of the solid line in Figure 3.

These elasticities do not differ greatly from those found in a 1972 study of Lake Tenkiller by Badger, et a1. (62, p. 101). The elasticity of demand for all users, since that study did not differentiate between non-fee and fee area users, was 0.59 .

The alternative lake related variables, $P_{2}$ (for Eufaula) and $P_{3}$ (for Fort Gibson), are not statistically significant. The t-values for each of the alternative price variables, for each user group indicate that their coefficients are not statistically different from zero. The economic implication of zero coefficients is that the alternative lakes of Eufaula and Fort Gibson are independent in the typical recreationist's decision to visit Lake Tenkiller. Hypothesis (2), which states that the prices of visits to alternative lakes are positively related to $R$, must therefore be rejected for the Tenkiller samples when only two alternatives are considered.

The remainder of the independent variables are income dummies representing four income classes. None of the coefficients are significantly different from zero for the non-fee area users. This implies that higher levels of income do not result in higher levels of demand. 
On the other hand, two of the coefficients of the income dummies are significant for the fee area sample.

Revealing as this might seem however, it is possible that the separate influences of each of the income dummies may be weak (strong) while their joint influence may be quite strong (weak) (36, p. 367). Thus, the appropriate hypotheses are:

$$
\begin{aligned}
& H_{0}: \beta_{i}=0 \\
& H_{A}: \beta_{i} \neq 0
\end{aligned}
$$

These hypotheses require a composite hypothesis test such as described by Rao and Miller (47, pp. 148-151). The results of the test are presented in Table XXI. When the calculated $F$ is greater than the tabled $\mathrm{F}, \mathrm{H}_{0}$ is rejected. The test indicates that $\mathrm{H}_{0}$ must not be rejected for either sample. Income does not significantly affect visitations for either of the recreation groups. Hypothesis (3), which states that income is positively related to $R$, must be rejected.

\section{TABLE XXI}

SUMMARY OF F-TEST ON INCOME DUMMIES:

LAKE TENKILLER

\begin{tabular}{lcccc}
\hline $\begin{array}{c}\text { User } \\
\text { Classification }\end{array}$ & $\begin{array}{c}\text { Nul1 } \\
\text { Hypothesis }\end{array}$ & $\begin{array}{c}\text { Degrees of } \\
\text { Freedom }\end{array}$ & $\begin{array}{c}\text { Calculated } \\
F\end{array}$ & $\begin{array}{c}\text { Tabled } \\
F(.05)\end{array}$ \\
\hline Non-fee & $B_{i}=0, i=4,5,6$ & $(3,136)$ & 0.2500 & 2.68 \\
Fee & $B_{i}=0, i=4,5,6$ & $(3,102)$ & 2.6615 & 2.70 \\
\hline
\end{tabular}


Hypothesis (4) states that there are significantly different demand curves for non-fee and fee area users. This hypothesis implies that the regression coefficients for each of the independent variables in the non-fee sample are statistically different from the corresponding coefficients in the fee area sample. The appropriate hypotheses are:

$$
\begin{aligned}
& H_{0}: \beta_{i}=\beta_{i} \quad j=0, \ldots, 6 \\
& H_{A}: \beta_{j} \neq \beta_{j}^{*}
\end{aligned}
$$

The $\beta_{j}$ 's are non-fee area coefficients; the $\beta_{i}^{\prime 1} s$ are fee area coefficients. This hypothesis requires a composite hypothes is test. The results of the composite hypothes is test are summarized in Table XXII. The null hypothesis of identical populations $\left(\beta_{j}=\beta_{j}, j=0, \ldots, 6\right)$ cannot be rejected at the 5 percent level of significance. That is, when considering all variables simultaneously there is no statistical difference between the demand curves of the two user groups.

TABLE XXII

SUMMARY OF F-TEST ON JOINT HYPOTHESES OF DIFFERENCE BETWEEN NON-FEE AND FEE AREA USERS:

LAKE TENKILLER

\begin{tabular}{llcc}
\hline$H_{0}:$ & $\begin{array}{c}\text { Degrees of } \\
\text { Freedom }\end{array}$ & $\begin{array}{c}\text { Calculated } \\
F\end{array}$ & $\begin{array}{c}\text { Tabled } \\
F(.05)\end{array}$ \\
\hline$\beta_{i}=\beta_{i}$ & $(7,238)$ & 1.7328 & 2.04 \\
$(i=0, \ldots, 6)$ & & & \\
\hline
\end{tabular}


In summary, both groups of users appear to respond similarly to own price. Neither Eufaula Lake or Fort Gibson Lake seem to be viable alternatives to the typical Lake Tenkiller user. Income has no significant influence on visitor days for the four month recreation period.

Given the evaluation and interpretation of the model estimated for the Lake Tenkiller samples, consider next the estimation of the model for Lake Eufaula and Lake Fort Gibson.

\section{Recreation Demand Curves: Lake Eufaula and Lake Fort Gibson}

The regression coefficients for equation (11) estimated for Lake Eufaula and Lake Fort Gibson are presented in Tables XXIII and XXIV respectively. The coefficients in general have plausible signs; the

coefficient of determination $\left(R^{2}\right)$ is higher in non-fee areas, . 33 versus .31 at Lake Eufaula and .42 versus .25 at Fort Gibson for non-fee and fee areas samples respectively. A test of the null hypothesis that the demand model has no power for explaining variations in visitor days is rejected at the five percent level for the Lake Eufaula non-fee sample and at the one percent level for all other samples.

The coefficients of own price are negative and highly significant for both non-fee and fee area samples at both lakes. Therefore, as was the case for the Lake Tenkiller samples, hypothesis (1) which states that quantity demanded and own price are negatively related cannot be rejected. The own price elasticities for non-fee and fee area users are respectively, -0.762 and -0.905 at Lake Eufaula; -0.805 and -0.671 at Lake Fort Gibson.

The interpretation of the alternative lake related variables are 
TABLE XXIII

REGRESSION COEFFICIENTS AND t-VALUES FOR WATER-BASED

OUTDOOR RECREATION DEMAND MODEL:

LAKE EUFAULA

\begin{tabular}{lcccc}
\hline & \multicolumn{3}{c}{ Sample } \\
\cline { 2 - 5 } $\begin{array}{c}\text { Independent } \\
\text { Variables }\end{array}$ & Coefficient & t-value & Coefficient & t-value \\
\cline { 2 - 5 } Constant & 2.043 & $2.212^{*}$ & 2.596 & $5.183^{* *}$ \\
$P_{1}$ & -0.762 & $-3.086^{* *}$ & -0.905 & $-5.266^{* *}$ \\
$P_{2}$ & 0.598 & 0.586 & -0.685 & -1.633 \\
$P_{3}$ & -0.054 & -0.052 & 1.270 & $2.496 *$ \\
$D_{4}$ & -0.133 & -0.170 & 0.073 & 0.232 \\
$D_{5}$ & -0.561 & -0.066 & -0.069 & -0.291 \\
$D_{6}$ & 0.187 & 0.205 & -0.148 & -0.541 \\
$R^{2}$ & .33 & & .31 & \\
\hline
\end{tabular}

** Significant at the 1 percent level.

* Significant at the 5 percent level. 
TABLE XXIV
REGRESSION COEFFICIENTS AND t-VALUES FOR WATER-BASED OUTDOOR RECREATION DEMAND MODEL:
LAKE FORT GIBSON

\begin{tabular}{lllll}
\hline & \multicolumn{3}{c}{ Sample } \\
\cline { 2 - 4 } $\begin{array}{c}\text { Independent } \\
\text { Variables }\end{array}$ & Non-fee Area & \multicolumn{2}{c}{ Fee Area } \\
\cline { 2 - 5 } Constant & 3.005 & t-value & Coefficient & t-value \\
$P_{1}$ & -0.805 & $-7.165 * *$ & -0.671 & $6.243^{* *}$ \\
$P_{2}$ & 0.064 & 0.214 & -0.474 & $-4.707 * *$ \\
$P_{3}$ & 0.270 & 0.884 & 0.853 & -1.039 \\
$D_{4}$ & -0.136 & -0.641 & -0.163 & 1.791 \\
$D_{5}$ & -0.460 & -1.846 & -0.201 & -0.595 \\
$D_{6}$ & -0.339 & -1.358 & 0.170 & -0.780 \\
$R^{2}$ & .42 & & .25 & 0.672 \\
\hline
\end{tabular}

** Significant at the 1 percent level 
similar to the Tenkiller sample for non-fee areas at Eufaula Lake and both areas at Fort Gibson Lake. The alternative lake related variables, $P_{2}$ and $P_{3}$, are not statistically different from zero. The economic implication of zero coefficients is that the alternative lake variables are independent in the average non-fee area recreationist's decision to visit Lake Eufaula or Lake Fort Gibson. Hypothesis (2), which states that the prices of visits to alternative lakes are positively related to $R$, must be rejected for the non-fee sample at Eufaula Lake and for both samples at Fort Gibson Lake.

This same conclusion does not hold for the fee area sample at Eufaula Lake. In this case, the coefficient of $P_{3}$ is statistically significant (Table XXIII). The positive sign, since $P_{3}$ corresponds to Lake Tenkiller as an alternative to Lake Eufaula, indicates that as the price of visiting Tenkiller increases, recreationists will substitute visits to Lake Eufaula. Since all the fee areas at Eufaula are located in a limited geographical area and are characterized by clear water it is the opinion of the author that this particular section of Lake Eufaula represents a close substitute for the type of recreation experience which exists at Lake Tenkiller.

All five public use areas in the clear water portion of Lake Eufaula are fee areas. The remaining 19 public use areas are located on a part of the lake characterized by murkey or muddy water. The attractability factor associated with the clear water portion of Lake Eufaula is probably very similar to that associated with the Lake Tenkiller recreation experience.

Hence, Hypothesis (2), which states that the prices of visits to alternative lakes are positively related to $R$, must not be rejected for 
the fee area sample at Eufaula Lake when Tenkiller Lake is the specified alternative lake.

The remaining explanatory variable of interest is income. None of the coefficients of the income dummies are significantly different from zero by the t-test. The more important test however, and the one that allows a conclusion to be reached with respect to Hypothesis (3), involves the joint influence of all the dummy variables. The results of this test are presented in Table XXV. The null hypothesis of zero income response cannot be rejected for any of the four samples at the 5 percent level of significance. Therefore, Hypothesis (3), which states that income is positively related to $R$, must be rejected for these four samples. Income has no significant effect on visitor days for these samples.

TABLE XXV

SUMMARY OF F-TEST ON INCOME DUMMIES:

LAKE EUFAULA AND LAKE FORT GIBSON

\begin{tabular}{llllll}
\hline Lake & $\begin{array}{c}\text { User } \\
\text { Classi- } \\
\text { fication }\end{array}$ & $\begin{array}{c}\text { Nuil } \\
\text { Hypothesis }\end{array}$ & $\begin{array}{c}\text { Degrees } \\
\text { of } \\
\text { Freedom }\end{array}$ & $\begin{array}{c}\text { Calcu- } \\
\text { lated } \\
F\end{array}$ & $\begin{array}{c}\text { Tabled } \\
\text { F } \\
(.05)\end{array}$ \\
\hline Eufaula & Non-fee & $\beta_{i}=0, i=4,5,6$ & $(3,29)$ & .0666 & 2.93 \\
& Fee & $\beta_{i}=0, i=4,5,6$ & $(3,69)$ & .1635 & 2.74 \\
Fort Gibson & Non-fee & $\beta_{i}=0, i=4,5,6$ & $(3,79)$ & 1.3847 & 2.72 \\
& Fee & $\beta_{i}=0, i=4,5,6$ & $(3,80)$ & .8827 & 2.72 \\
\hline
\end{tabular}


Hypothesis (4) implies that the regression coefficients for each of the independent variables in the non-fee sample are statistically different from the corresponding coefficients in the fee area sample. The results of testing the hypothesis for Lake Eufaula and Lake Fort Gibson are presented in Table XXVI. The $\beta_{i}$ 's are non-fee area coefficients; the $\beta_{j}^{\prime \prime} s$ are fee area coefficients.

\section{TABLE XXVI}

SUMMARY OF F-TEST ON JOINT HYPOTHESES OF DIFFERENCE BETWEEN NON-FEE AND FEE AREA USERS: LAKE EUFAULA

AND LAKE FORT GIBSON

\begin{tabular}{lllcc}
\hline Lake & $H_{0}:$ & $\begin{array}{c}\text { Degrees of } \\
\text { Freedom }\end{array}$ & $\begin{array}{c}\text { Calculated } \\
F\end{array}$ & $\begin{array}{c}\text { Tabled } \\
F(.05)\end{array}$ \\
\hline Eufaula & $\beta_{j}=\beta_{i}^{\prime}$ & $(7,98)$ & 1.2626 & 2.10 \\
Fort Gibson & $(i=0, \ldots, 6)$ & & & \\
& $\beta_{j}=\beta_{j}$ & $(7,159)$ & 1.4529 & 2.06 \\
& $(j=0, \ldots, 6)$ & & & \\
\end{tabular}

The null hypothesis of identical populations $\left(\beta_{\hat{j}}=\beta_{\hat{j}}, \hat{i}=0, \ldots, 6\right)$ cannot be rejected at the 5 percent level of significance. When considering all variables simultaneously there is no statistical difference between the two user groups at either Lake Eufaula or Lake Fort Gibson. In summary, both groups of users, evaluated separately at each lake, appear to respond similarly to own price. Neither possible 
al ternative lake influenced visitor days for non-fee users at either Lake Eufaula or Lake Fort Gibson. However, fee area users at Eufaula Lake apparently are affected by the availability of an alternative lake. This significant alternative is Lake Tenkiller. The income variable did not significantly influence visitor days for the four areas considered in this section. When judged at the 5 percent level of significance there are no apparent differences between non-fee and fee area users. Based on this conclusion, non-fee and fee area samples can be pooled and recreationists can be represented by a single average demand curve at each lake.

Recreation Demand Curves: Pooled Data

The pooled data provides the basis for an empirical investigation of the theoretical construct outlined in Chapter III related to recreationists' response to travel costs as opposed to recreationists' response to fees. That discussion suggests the model:

$$
R=b_{0}+b_{1} P_{1}+b_{2} P_{2}+b_{3} P_{3}+b_{4} D_{4}+b_{5} D_{5}+b_{6} D_{6}+b_{7} D_{7}
$$

where the "new" variable $D_{7}$ is an intercept dummy. $D_{7}=0$ if an observation is from a non-fee area; $D_{7}=1$ if an observation is from a fee area.

The regression coefficients for equation (21) estimated for the pooled samples at each of the three lakes are presented in Table XXVII. Once again the coefficients have plausible signs; the coefficient of determination $\left(R^{2}\right)$ ranges from .23 at Lake Tenkiller to .32 at Lake Fort Gibson; the null hypothesis that the demand model has no power for explaining variations in visitor days is rejected at the one percent level in every case. 
TABLE XXVII

REGRESSION COEFFICIENTS AND $t$-VALUES FOR WATER-BASED OUTDOOR RECREATION DEMAND MODEL: LAKE TENKILLER, LAKE EUFAULA, AND LAKE FORT GIBSON

\begin{tabular}{|c|c|c|c|c|c|c|}
\hline \multirow{3}{*}{$\begin{array}{c}\text { Independent } \\
\text { Variables }\end{array}$} & \multicolumn{6}{|c|}{ Sample } \\
\hline & \multicolumn{2}{|c|}{ Tenkiller } & \multicolumn{2}{|c|}{ Eufaula } & \multicolumn{2}{|c|}{ Fort Gibson } \\
\hline & Coefficient & t-value & Coefficient & t-value & Coefficient & t-value \\
\hline Constant & 3.287 & $13.809 * *$ & 2.052 & $4.193 \star \star$ & 2.887 & $10.907 * *$ \\
\hline$P_{1}$ & -0.701 & $-8.218 * *$ & -0.810 & $-6.111 * *$ & -0.744 & $-8.492 * \star$ \\
\hline$P_{2}$ & 0.070 & 0.489 & -0.252 & -0.673 & -0.135 & -0.532 \\
\hline$P_{3}$ & 0.170 & 1.446 & 0.792 & 1.803 & 0.479 & 1.840 \\
\hline $\mathrm{D}_{4}$ & -0.219 & -1.299 & 0.051 & 0.187 & -0.123 & -0.729 \\
\hline$D_{5}$ & -0.182 & -1.192 & 0.047 & 0.204 & -0.318 & -1.793 \\
\hline$D_{6}$ & -0.177 & -1.288 & 0.041 & 0.150 & -0.068 & -0.384 \\
\hline$D_{7}$ & 0.256 & $2.292 *$ & 0.516 & $2.432 *$ & 0.294 & $2.322 *$ \\
\hline$R^{2}$ & .23 & & .30 & & .32 & \\
\hline
\end{tabular}

** Significant at the 1 percent level.

* Significant at the 5 percent level. 
The coefficients of own price are negative and highly significant for all three 1akes. Therefore, Hypothesis (1) cannot be rejected for any of the pooled samples. The analys is of alternative prices, $P_{2}$ and $P_{3}$, reveals no significant alternative for any of the three data sets. When estimated using the pooled data, none of the income dummies have significant coefficients when evaluated by the t-test. The results of an F-test on the joint influence of the income variables are presented in Table XXVIII. The null hypothesis of no response to income (i.e. $\beta_{i}=0, i=4,5,6$ ) cannot be rejected for any of the three samples.

TABLE XXVIII

SUMMARY OF F-TEST ON INCOME DUMMIES, POOLED DATA: LAKE TENKILLER, LAKE EUFAULA, AND LAKE FORT GIBSON

\begin{tabular}{lccc}
\hline Lake & $\begin{array}{c}\text { Degrees of } \\
\text { Freedom }\end{array}$ & $\begin{array}{c}\text { Calculated } \\
F\end{array}$ & $\begin{array}{c}\text { Tabled } \\
F(.05)\end{array}$ \\
\hline Tenkiller & $(3,244)$ & .9643 & 2.64 \\
Eufaula & $(3,104)$ & .0193 & 2.70 \\
Fort Gibson & $(3,165)$ & 1.1601 & 2.66 \\
\hline
\end{tabular}

The statistical analysis related to the income variable for each of the three pooled samples indicated that recreationists with higher incomes are no more likely, on average, to participate in water-based 
outdoor recreation at a higher rate than lower income recreationists. Two related explanations for this finding are the rising levels of income in general, and possibly expanding credit availability. Individuals who previously did not participate in water-based outdoor recreation because the entry costs were high (i.e. boats, campers, and other auxiliary equipment) may have the opportunity to do so now. These factors could result in a narrowing of differences between income classes and an equalizing of recreation participation rates.

\section{A Hypothetical Experiment With Camping Fees}

Recreationists' response to the price variable, and its implicit relationship with fees warrant further discussion. Based on the three demand curves reported in Table XXVII an analysis of an average recreation group's response to increased camping fees can be accomplished.

\section{Recreationist's Response to Fees}

The intercept dummy $D_{1}$ is significantly different from zero for all three lakes (Table XXVII). In terms of the theoretical construct in Chapter III, the significant coefficient for the intercept dummy indicates that recreationists do respond differently to travel costs than to user fees. But, as discussed in Chapter III, the bias resulting from assuming equal response is such that any estimated change in visitor days will be overstated. Thus the resulting estimate of revenue accruing from increased fees will be greater than estimated under the equal response assumption. Thus, the experiment to follow will result in a "conservative" estimate of changes in revenue due to increasing the level of fees. 
In the present study, recreationists who are responding to fees behave very similar to persons whose price variable does not contain an expenditure on fees. This conclusion must be tempered by the possible existence of an emotional factor which would decrease visitations, as fees increased, beyond the level suggested by the recreationists response to economic variables. One of the main factors involved here is the firm belief by some that the recreation areas have already been paid for by taxes and they feel they are being subjected to double taxation. This argument fails, however, to recognize the problem of development costs as opposed to operation and maintenance costs as separate financial functions.

Based on the pooled sample equations the effects of different levels of fees on recreation attendance and revenue from camping fees are analyzed. The experiment is conducted on the assumption that a11 overnight campers will pay a camping fee. The average recreation group demand curves from Table XXVII evaluated for mean values of the independent variables, are used as a base and incremental increases of first $\$ 1.00$ and then $\$ .50$ per night per group are analyzed. Since price is measured in dollars per visitor day, the incremental fee increases must also be in dollars per visitor day. Hence, each incremental increase in fees will be divided by average number of persons per group at each lake respectively. These averages are, 3.5 at Lake Fort Gibson; 3.7 at Lake Eufaula; and 4.3 at Lake Tenkiller. Thus, a $\$ 1.00$ per night increase in camping fees at Lake Tenkiller is on average about $\$ .23$ per person per night. This hypothesized increase in fee per visitor day is added directly to average price per visitor day. The new average price including fees is then entered into the appropriate demand equation to estimate 
the effect on recreation visitations for the four month period. The estimated average four month attendance is then multiplied by average fee per visitor day to yield average revenue from fees for an average recreation group. The results of this hypothetical experiment are reported in Table XXIX.

As expected, an increase in fees resulted in a decrease in visitations over the four month recreation period. At Lake Tenkiller for example a $\$ 1.00$ increase in fees would reduce visitations for the average group from 40.78 visitor days to 36.60 ; an additional $\$ .50$ increase would reduce visitation to 34.79 visitor days; and another $\$ .50$ increase would reduce visitations to 33.19 visitor days. Each $\$ 1.00$ increase in fees reduces visitations at Tenkiller and Eufaula Lakes by three to four visitor days and by five to six at Fort Gibson Lake for the average recreation group.

However, at the same time visitor days are decreasing, revenue collections from the camping fees are increasing. The first dollar increase in fees at Lake Tenkiller results in an additional $\$ 6.44$ revenue from the average group over the four month period. An additiona1 $\$ .50$ increase would increase this total to $\$ 9.17$; another $\$ .50$ increase, representing a $\$ 2.00$ fee level over the base, would generate $\$ 11.56$ in fee revenue from the average group over the four month period when fees are collected.

This hypothetical experiment suggests that managing officials of these recreation areas could increase their revenue from camping fees by increasing the charge on overnight campers. Tempered by the caveat concerning an emotional rejection of fees, visitations will probably not be reduced greatly by such a policy. 
TABLE XXIX

ESTIMATES OF AVERAGE ATTENDANCE PER GROUP AND FEE REVENUE FROM AN AVERAGE GROUP FOR DIFFERENT LEVELS OF FEES

\begin{tabular}{|c|c|c|c|}
\hline Lake & $\begin{array}{c}\text { Fee } \\
\text { Levela }^{\mathrm{a}} \\
\text { (Dollars) }\end{array}$ & $\begin{array}{l}\text { Average } \\
\text { Attendance } \\
\text { Per Group } \\
\text { (Visitor Days) }\end{array}$ & $\begin{array}{c}\text { Fee Revenue } \\
\text { From Average } \\
\text { Groupc } \\
\text { (Dollars) }\end{array}$ \\
\hline \multirow[t]{4}{*}{ Tenkiller } & Base & 40.78 & -- \\
\hline & 1.00 & 36.60 & 6.44 \\
\hline & 1.50 & 34.79 & 9.17 \\
\hline & 2.00 & 33.19 & 11.56 \\
\hline \multirow[t]{4}{*}{ Eufaula } & Base & 37.04 & -- \\
\hline & 1.00 & 32.49 & 6.77 \\
\hline & 1.50 & 30.58 & 9.50 \\
\hline & 2.00 & 28.91 & 11.62 \\
\hline \multirow[t]{4}{*}{ Fort Gibson } & Base & 42.07 & -- \\
\hline & 1.00 & 35.30 & 8.21 \\
\hline & 1.50 & 32.69 & 11.05 \\
\hline & 2.00 & 30.49 & 13.39 \\
\hline
\end{tabular}

${ }^{\mathrm{a}}$ Calculations in the first row of each lake (where fee level = base) are made at the sample mean value for each variable in equation (21) estimated for each lake separately.

${ }^{b}$ Average attendance per group is measured in visitor days and refers to the four month period when fees are charged. Average group size was, 4.3 at Lake Tenkiller; 3.7 at Lake Eufaula; 3.5 at Lake Fort Gibson.

${ }^{\mathrm{C}}$ Given the average visitor days per group per trip (Table XIX), and the average attendance per group reported above, the average recreation group makes approximately 2 trips during the four month recreation period. Thus, 2 times the average number of persons per group is the number of visitor days not subject to fees. They are 8.6 , 7.4 , and 7.0 visitor days, respectively, at Tenkiller, Eufaula, and Fort Gibson Lakes. These are subtracted from average attendance per group before fee revenue is computed (i.e. a group staying three days, pays fees for only two nights. 
The major limitation of this analysis of fees is in the constant elasticity of demand assumption which is implied by the model. As fees are continually increased, given the estimated elasticity of demand (inelastic in all cases), revenue from fees will also increase. At some point in time, as fees are continually increased, elasticity of demand may increase. Increased fees also increase the price variable, and price therefore becomes a larger part of the individuals total recreation budget. At that point where elasticity of demand becomes elastic, additional increases in fees will reduce total revenue from fees as visitations begin to decrease relatively more than fees are increasing。

This analysis must also be tempered by a recognition of the level of confidence that is placed in the point estimates of average visitor days per group for each level of fees. Johnston outlines the procedure for estimating prediction intervals which, in the present case, result in a range of values for the dependent variable as opposed to a point estimate (38, pp。152-155). This prediction interval will contain the actual value of the dependent variable $(R)$ with whatever probability we choose (36, p. 374). A 95 percent prediction interval for average attendance per group at Tenkiller Lake, evaluated at the mean values of the independent variables, ranges from 36.63 to 45.40 visitor days. ${ }^{2}$ This range indicates an approximate plus or minus 4 visitor days above or below the point estimate of 40.78 visitor days per group. The implication of the prediction interval is straight forward. If actual

${ }^{2}$ Since the original model is estimated in natural log form, the "true" 95 percent prediction interval refers to that original model. Hence, when the variable $R$ is converted back to an actual measure of visitor days it is not a "true" 95 percent prediction interval. 
visitor days per group are less than the point estimate, revenue from fees will be less than indicated in Table XXIX. If actual visitor days per group are greater than the point estimate, revenue from fees will be greater than estimated in Table XXIX.

Similar prediction intervals for Eufaula Lake bound the point estimates for different fee levels by approximately plus or minus 6 visitor days. At Fort Gibson Lake the intervals are about plus or minus 4.5 visitor days above or below the point estimates.

The range of each prediction interval differs very little as increasingly higher levels of fees are considered. For Tenkiller Lake the largest interval is 8.76 visitor days in length, the shortest is 7.87. Similarly, the largest and smallest intervals for Eufaula Lake are 12.95 and 11.14 visitor days, respectively. For Fort Gibson Lake the intervals range from 10.27 to 8.76 visitor days.

These "(i)ntervals have more meaning for predictions made for future periods close to the sample period and less meaning as the future periods move farther away from it" (19, p.364). Thus, if structural changes are expected to occur in the model, new observations are needed to make better predictions for the next future period.

\section{Summary}

This summary states the conclusions of the empirical estimation and analysis in the present chapter with respect to each of the four major hypotheses as well as summarizing the results of a fee experiment.

The four hypotheses are:

Hypothesis 1: Quantity demanded and own price are negatively related. 
Hypothesis 2: Quantity demanded and prices of alternative lakes are positively related.

Hypothesis 3: Quantity demanded and income are positively related.

Hypothesis 4: There are significantly different demand curves for non-fee area users and fee area users.

Hypothesis (1) could not be rejected for any of the samples analyzed. Price elasticity of demand was relatively inelastic for each lake and no significant differences were found between fee area and nonfee area users with respect to these elasticities.

Hypothesis (2) was rejected for a 11 lakes. A11 three lakes reflected an independent relationship between visitations and the aiternative lake variables specified in the model.

Hypothesis (3) was rejected for all lakes when evaluated for the pooled samples. Separate analysis of fee area and non-fee area data revealed no case where income was significant and positively related to visitations during the four month study period.

Hypothesis (4) was rejected for all lakes. No statistically significant differences existed between fee area and non-fee area users when evaluated at the 5 percent level of significance.

When the data are pooled with only an intercept dummy distinguishing between fee and non-fee area users, the dummy variable is significant. The implication of this is that recreationists' do respond differently to user fees than to travel costs. However, it is concluded that a "conservative" estimate of visitor days per recreation period can be obtained under the equal response assumption. Based on empirical estimates of visitor days it is concluded that nominal increases in camping fees will increase revenue from the recreation areas without 
substantially decreasing visitations.

The following chapter summarizes the results of this study, discusses policy implications, and suggests areas for further research. 


\section{CHAPTER VI}

\section{SUMMARY AND CONCLUSIONS}

At the Corps of Engineer's lakes in 0klahoma there are no entrance fees per se. However, provision of water-based outdoor recreation can be classified into two types. One type includes the public use areas which require no payment for overnight use. Another type includes the fee areas for which a payment must be made for overnight use of the area. Previous studies have not taken this dual level of provision into consideration. The general objective of the present study was to compare and contrast non-fee and fee area users at three lakes in Eastern Oklahoma. Specific objectives were: (1) to analyze traditional aspects of providing water-based outdoor recreation by public institutions; (2) to analyze consumption activities related to water-based outdoor recreation; (3) to estimate statistical demand curves for water-based outdoor recreation; and (4) to analyze implications for future water-based outdoor recreation policy.

The need for the study arose from the changing philosophy which has occurred with respect to charging fees for outdoor recreation facilities. This changing philosophy is reflected in legislation related to water-based outdoor recreation $(1,54,57,58,59)$. The development of

these laws has resulted in giving fees a definite role in financing future water-based outdoor recreation projects.

Tenkiller, Eufaula, and Fort Gibson Lakes were chosen for the 
present study because of their relative importance in terms of reported visitor days. Each of the three lakes have accounted for more than 4,000,000 visitor days both in 1973 and 1974 and will 1ikely exceed 4.5 million visitor days in 1975 .

Primary data were obtained from 550 recreation groups, interviewed on-site during the summer of 1974. Recreationists provided data on; (1) socioeconomic characteristics; (2) site preferences and opinions; (3) expenditure patterns; and (4) visitation patterns.

Summary and Policy Implications

Provision

The analysis of provision of water-based outdoor recreation points to a changing philosophy with respect to who should pay for outdoor recreation facilities. Many of the traditional arguments for providing "free" outdoor recreation are not economically justified. Provision of water-based outdoor recreation at zero or near-zero prices is apparently losing the support it once had. Interest is growing in favor of more user fees. Beneficiaries are probably going to pay an increasing share of the cost of providing facilities.

\section{$\underline{\text { Recreationists' Data }}$}

The average size of a recreation group was very similar between non-fee and fee area users at any particular lake. A difference does exist between lakes, however, as Tenkiller Lake recreationists averaged more persons per group (4.3) than either of the other two lakes (3.7 at Eufaula; 3.5 at Fort Gibson). The average length of stay of overnight users ranges from a low of slightly more than four days for fee area 
users at Fort Gibson Lake to a high of 6.6 days for non-fee users at Tenkiller Lake.

Average miles traveled to reach the lake varies from 79 miles for Fort Gibson fee area users to 155 miles for fee area users at Tenkiller Lake. All three lakes are characterized by relatively more visits from those travel zones containing a large metropolitan area.

These recreationists' data impact greatest on policy by indicating intensity of use of a given recreational facility. The larger recreation groups and longer length of stay which characterize Tenkiller Lake users relative to the other two lakes may require more frequent trash collection, patrolling of recreation areas, or repair of facilities. If this is so, costs of operating a recreation area will also be greater at Lake Tenkiller relative to Eufaula and Fort Gibson. Therefore, in a strict economic sense, this cost should be weighed in any decision related to the amount of camping fees to be charged at any given facil-ity. If beneficiaries are to pay for recreational facilities, as the emerging philosophy suggests, differential fee policies may be called for depending on facility use. The present study is concerned only with overnight camping fees, but similar consideration could be given to entrance fees or day use fees.

The analysis of socioeconomic characteristics of respondents did not reveal any substantial differences between fee and non-fee area users. However, there were some differences among recreationists between lakes, and several of the socioeconomic variables did appear to influence participation rates of recreationists. Probably the most important of these variables are age, education level, income, and type of employment. Conclusions based on any one of these variables should 
be tempered by the recognition that they are highly interrelated. A change in one will most likely impact on one or more of the other variables.

Fee area users were more predominant in the age range from 30 to 49 years of age. Recreationists younger than 30 and older than 50 were more likely to be in a non-fee area.

Tenkiller Lake is characterized by relatively more respondents with higher levels of education compared to the other two lakes. Forty percent of Tenkiller respondents had more than a high school education. Only 29 percent of the Fort Gibson and Eufaula samples reported education levels greater than high school. There are no significant differences between fee area and non-fee area users at any of the three lakes for the education variable. In general, recreationists sampled in this study had higher than average education levels (compared to all Oklahomans). This suggests that persons with higher education levels are more likely to engage in water-based outdoor recreation than those persons with less education.

Median family income ranged from approximately $\$ 10,500$ at Fort Gibson Lake to about $\$ 13,500$ at Eufaula and Tenkiller lakes. These figures are considerably higher than the $\$ 7,725$ median household income for residents of 0klahoma. Thus it appears that persons with higher household incomes are more likely to participate in water-based outdoor recreation than those with less income. There is little difference between the income distribution for non-fee and fee area users. About 75 percent or more of the recreationists, at all three lakes, are included in the income classes above $\$ 9,000$.

The distribution of non-fee and fee area users with respect to type 
of employment reflects a relatively similar distribution of occupations across a11 lakes. Two occupational classifications, professional, and manager or administrator, account for 25 percent or more of respondents across all three lakes. Craftsmen add an additional 10 percent to this group which would also be expected to obtain higher levels of income.

As mentioned before, the age, education level, income, and type of employment variables are highly interrelated. Persons with higher levels of education are more likely to be professionals or administrators; professionals or administrators are more likely to earn higher incomes; and recreationists in the 30 years and older age range are more likely to earn higher levels of income. These considerations should temper the various policy implications.

If a policy goal is increased visitations to a particular lake, promotional activities on the part of recreation area administrators which "educate" the public would likely attract more recreationists. Other persons with characteristics similar to those recreationists already using the lakes are probably susceptible to such promotional activities. The higher level of education evidenced in the present study indicates that, in general, recreationists are capable of learning about facilities and learning "how" to engage in activities associated with various water-based outdoor recreation facilities.

The policy implications of socioeconomic characteristics with respect to fee payments are most strongly related to income. Income level, of course, is influenced by many other socioeconomic variables. The findings of the present study suggest that most of the recreationists using the public use areas do possess the ability to pay nominal fees for facility use. This conclusion should not be construed to indicate a 
willingness to pay, but only an ability. The motivational aspects of recreationist's willingness to pay have not been investigated in the present study。

A final policy implication relates to water-based outdoor recreation as an instrument of income redistribution. The present findings suggest, since most of the current users of recreation facilities are from higher income classes, "free" water-based outdoor recreation is a poor instrument for income redistribution. It is little more than a subsidy to those persons who already have the necessary equipment (i.e. boats, skis, camping equipment, etc.) to engage in the recreational activity. Until provision includes travel to and from the site as well as ancillary equipment, free recreation facilities will have little meaning to low income groups who otherwise cannot even afford to visit such facilities.

\section{Facility Preferences of Recreationists}

The facility preferences of recreationists can be summed up in one statement. Generally, more and/or better facilities are desired by recreationists. It is the composition of desired facilities which are apparently changing. Evidently people want to maintain some degree of attachment to the so called "creature comforts" of everyday city life. Improvements such as showers, electric outlets, and flush type toilets are cited more often than activity related items such as boat ramps, swimming areas, or campsites.

Problem areas most of ten cited were dirty toilets, noise problems due to land vehicles, and insufficient security patrol.

Facility preferences of recreationists impact directly on development 
aspects of facility management. New facilities and replacement facilities can better meet the demands of recreationists by recognizing current facility preferences. Findings of the current study suggest that activity related items such as boat ramps, swimming areas, and campsites may be adequate, in number at least, for the three lakes surveyed. Future developments and improvements should concentrate on utilities such as showers, flush type toilets, and electric outlets. On average, the recreationists today want to maintain the comforts of everyday city living even when on a camping trip.

The problem of noise due to land vehicles could increase in the future due to growing numbers of recreationists obtianining mini-bikes and motor cycles. Zoning regulations or some manner of specifying particular areas for cycling could improve this problem. Consideration of non-compatible activities such as this, or similarly the potential conflict between boaters and swimmers using the same areas (52, p.90), should enter the decision framework of policy makers.

Differences that did appear in analyzing facility preferences of recreationists were more likely to be between lakes rather than between non-fee or fee area users. This finding in itself is indicative of the problem of "good" outdoor recreation management. A "good" policy at one lake may not be as "good" at another.

\section{Empirical Estimation of Demand}

The demand analysis was approached at a behavioral level. Demand curves of the form $R=b_{0} P_{1}^{b_{1}} P_{2}^{b_{2}} P_{3} b_{3} e_{i} b_{j} D_{i} \quad i=4,5,6$, were estimated at each of the three lakes and or each user classification. Visitor days per group for the four month period June, July, August, and 
September was used as the dependent variable $(R) ; P_{1}$ is travel costs plus fees per visitor day to reach the lake; $P_{2}$ is the travel cost (i.e. price) to an alternative lake; $P_{3}$ is the travel cost (i.e. price) to a second alternative lake; $D_{4}, D_{5}$, and $D_{6}$ are dummy variables for income. The model was converted to logarithms and estimated by linear regression techniques.

The purpose of the empirical dichotomy was to test for a difference between non-fee and fee area users' demand. Finding no significant difference between non-fee and fee area users response to the independent variables, the data for each of two user groups were pooled at each of the three lakes. Average demand curves were then fitted to the pooled data at each lake.

A second model of the form, $R=b_{0} P_{1} b_{1} P_{2}^{b_{2}} P_{3} b_{3} e_{i} b_{i} D_{i} \quad i=4,5,6$, 7 was used for the pooled data. The "new" variable $D_{7}$ is an intercept dummy which allows the constant term in the regression to be different for each user group.

The coefficients of own price are negative and highly significant for all samples. The price elasticities for each sample are summarized in Table XXX.

None of the alternative lake variables were statistically significant. The lack of significant alternatives is probably indicative of repeated visitations by the same "hard-core" users at any particular lake. This could imply a lack of information about alternatives or simply a revealed preference for a single desirable recreation environment. The income variable did not prove to be a significant explanatory variable in the demand model. 
TABLE XXX

PRICE ELASTICITY OF DEMAND BY LAKE

AND USER GROUP, 1974*

\begin{tabular}{lccc}
\hline Lake & Non-fee Area & Fee Area & Pooled \\
\hline Tenkiller & -0.633 & -0.817 & -0.701 \\
& $(-5.717)$ & $(-6.025)$ & $(-8.218)$ \\
Eufaula & -0.762 & -0.905 & -0.810 \\
& $(-3.086)$ & $(-5.266)$ & $(-6.111)$ \\
Fort Gibson & -0.815 & -0.671 & -0.744 \\
& $(-7.165)$ & $(-4.707)$ & $(-8.492)$ \\
\hline
\end{tabular}

* t-value in parentheses.

The coefficient of $D_{7}$ was significant and positive, indicating that fee area users are characterized by a higher level of demand. At any given price, fee area users engage in more visitor days of waterbased outdoor recreation than their non-fee area counterparts.

The three demand equations, estimated for the pooled data (i.e. one demand curve for each lake) provided the basis for a hypothetical experiment with camping fees. As expected, an increase in fees results in a decrease in visitations over the four month recreation period studied. Each $\$ 1.00$ increase in fees reduced expected visitations by about four to five visitor days for the average recreation group. However, at the same time visitor days are decreasing, revenue collections from the camping fees increase. This is due to the inelastic demand exhibited by the demand curves. The first dollar increase in fees 
results in additional revenue from fees amounting to $\$ 6.44$ at Tenkiller Lake, \$6.77 at Eufaula Lake, and \$8.21 at Fort Gibson Lake, for an average group over the four month period.

No statistically significant differences existed between fee area and non-fee area users when evaluated at the 5 percent level of significance. This conclusion implies that it should be possible to charge camping fees at more recreation areas than are presently operating under a fee policy. Aside from an emotional rejection of fees, which was not measured in the present study, recreationists in each of the two user classifications respond similarly to economic variables at each of the three lakes. Nominal increases in camping fees (and implementation of fees where not presently charged) should increase revenue from the recreation areas without substantially decreasing visitations.

It should be noted that many recreationists need to be educated on the use of any user fee charged for recreational facilities. These fees go primarily for operation and maintenance of the facilities, including restroom supplies, provision of drinking water, and clean up of the recreational area including disposal of trash and other wastes. The fee is not double taxation; it is not for land acquisition and construction of recreational facilities $(3, p .8)$ 。

\section{Conclusions}

Water-based outdoor recreation cannot be considered available for the taking. Choices concerning monetary outlays are involved in most decisions to engage in water-based outdoor recreation. Normally a user will have to travel to the lake; he will normally invest money in supplies and equipment; and to an increasing degree he is likely to pay 
a nominal fee for use of the recreational facilities. In the present study this tendency to pay has been termed "the emerging philosophy." The conclusions reached in the present study are consistent with, and reinforce, the principles contained in the emerging philosophy.

The behavioral conclusions relating to non-fee versus fee area users suggest that most of those persons who are actually using the facilities do have the purchasing power and probably the motivation to pay nominal user fees. The pace of policy reforms with respect to water-based outdoor recreation probably will depend on how well interest groups inform government decision makers. Current information such as provided in this study is needed, but changing conditions make it obsolete very quickly. Changes in attitudes, tastes, and technology will change the estimated relationships. "However, a model based on the explicit characteristics of the environment is likely to be superior to one which simply assumes the existing structure" (51, p. 381). Short run progress in providing water-based outdoor recreation may well require that those in power substitute intuition and foresight for knowledge. Policy should be based not simply on how the world ought to be, but also on how it is.

\section{Limitations and Suggestions for Further Study}

The present study does not distinguish between different combinations of activities. Further research is needed to delineate the "mix" of recreational activities engaged in by recreationists using waterbased outdoor recreation facilities. In the present study only those persons staying overnight or longer were considered. Therefore, they were at least camping. The apparent relationship between activities, 
however, were of a multi-activity nature. Most recreationists engaged in several different activities during any particular visit to a lake. Identification of this mix of activities would enable researchers to better gage the economic impact of water-based outdoor recreation facilities with respect to specific activities. It would also enable planners to provide facilities which correspond to the activities persued by recreationists.

An area in which no information was obtained in the present study relates to visitation data for lakes other than the lake where the interview took place. Obtaining information on the other lakes visited by a recreation group during a particular period could help establish complementary or substitute relationships between lakes. This information would also indicate to what extent demand is distributed over different recreation groups.

Off-season use of water-based recreational facilities should be continually monitored. Efforts should be made to devise schemes which would increase off-season use. If increased use occurs in what is now the off-season, the same number of facilities currently available will accomodate the increased use. If the increased use occurs during the "recreation season," it may require more facilities. Consequently, the following off-season will be characterized by even more idle facilities.

A needed research area, which would complement the present effort, is an investigation into the demand for water-based outdoor recreation facilities by day users. Implicitly this should include analysis of user response to fees. If recreationists who stay for only a day (or less) were confronted with a user fee, it would probably represent a large part of their total expenditures, relative to overnight campers. 
Thus, they might respond differently than overnight campers to an equal increase in fees.

Given the principles contained in the emerging philosophy, another important area for future research relates to the moral or subjective response of recreationists to user fees. The emerging philosophy suggests that beneficiaries of the recreation areas should be asked to pay a nominal fee. Again, the present study found no significant difference between non-fee and fee area recreationists in their response to economic variables. However, no conclusion could be made on how much visitations would be reduced because of a recreationist's subjective rejection of fees. Consider the question, "If al1 camping areas at Tenkiller Lake had been fee areas, "would campers in non-fee areas have gone to another lake?" This question can only be answered by motivational research into recreationists' moral or subjective responses to user fees.

A11 of the 1 imitations of the present study and the suggestions for further study have, to this point, dealt with demand aspects of water-based outdoor recreation. However, if more and more federal public use areas have camping fees and State Parks go to camping fees, consideration should be given to the implications for increasing supply of private recreation facilities. The fee structure of public parks will influence the ability of private enterprise to profit in the recreation business. This relationship should warrant further study.

In the period of transition from few to more user fees it is helpful in planning future facilities to know how non-fee area users will respond to fees, and how fee area users will respond to higher fees. Improved methodology is needed if this goal is to be achieved. 
One suggested improvement would be to include supply variables (i.e., available facilities at a recreation area) in a model of waterbased outdoor recreation. Given the increased emphasis on fees, recreationists are faced with more and/or higher fees than in the past. If these higher costs associated with water-based outdoor recreation make recreationists more concerned with what they get for their money, supply variables may help explain visitations to particular recreation areas. To the extent that information is available to the public on existing facilities at different recreation areas, those facilities may enter the recreationist's decision calculus. Hence, supply variables could serve an explanatory purpose in future models of waterbased outdoor recreation.

Regardless of the need for a better methodology to explain the difference between fee area and non-fee area users, a large and important void exists in the availability of data. Especially time-series data. A better measure of how recreationists respond to fees could be developed from data extending over a long period of time. Ideally the data could be analyzed for recreationist's response to fees as fees are actually observed to increase. Given this information, researchers would not have to rely on hypothetical fee increases as in the present study. 


\section{SELECTED BIBLIOGRAPHY}

(1) Ad Hoc Resource Council. "Policies, Standards, and Procedures in the Formulation, Evaluation, and Review of Plans for Use and Development of Water and Related Land Resources." Supplement No. 1. Evaluation Standards for Primary Outdoor Recreation Benefits. Washington, D.C., June 4, 1964.

(2) Anderson, F. J., and N. C. Bonsor. "Allocation Congestion, and the Valuation of Recreation Resources." Land Economics, Vo1. 50 (February, 1974), pp. 51-57.

(3) Badger, Daniel D. "Economic and Environmental Management Considerations in Water and Related Land Based Recreation." Paper presented at Seminars on Economics, Pollution, and Recreation, Jefferson City, Mo., Apri1 24, 1975 and Osage Beach, Mo., Apri1 25, 1975.

(4) Badger, Daniel D., and John G. McNeely. Demand for Selected Recreational Activities in South Central 0k Tahoma. Technical Bulletin T-126. Stil1water: 0klahoma State University Experiment Station, May, 1968.

(5) Boyet, Wayne E., and George S. Tolley. "Recreation Projection Based on Demand Analysis." Journal of Farm Economics, Vol. 48, No. 2 (November, 1966), pp. 984-1001.

(6) Bromley, Daniel W., Walter R. Butcher, and Stephen C. Smith. "Policy and Research Implications of the National Water Commission's Recommendations." Land Economics, Vol. 50 (February, 1974), pp. 15-34.

(7) Brown, William G., and Farid Nawas. "A New Approach to the Evaluation of Non-priced Recreation Resources: A Reply。" Land Economics, Vo1。48 (November, 1972), pp。403-305.

(8) Brown, Willyam G., and Farid Nawas. "Impact of Aggregation on the Estimation of Outdoor Recreation Demand Functions." American Journal of Agricultural Economics, Vo1. 55, No. 1 (May, 1973), $\overline{\mathrm{pp} .246}-\overline{249}$.

(9) Burkhead, Jesse, and Jerry Miner. Public Expenditure. New York: Aldine and Atherton, 1971.

(10) Carey, Omer L. "The Economics of Recreation: Progress and Problems." The Western Economic Journal, Vol. 3-4 (Spring, $1965), \mathrm{pp}$. $1 \overline{72-1} \overline{81}$. 
(11) Cicchetti, Charles J., Anthony C. Fisher, and Kerry V. Smith. "Economic Models and Planning Outdoor Recreation." Operations Research, Vo1. 21 (September, 1973), pp. 1104-1113.

(12) Cicchetti, Charles J., Joseph J.Seneca, and Paul Davidson. The Demand and Supply of Outdoor Recreation. New Brunswick, New Jersey: Bureau of Economic Research, Rutgers-The State University, 1969.

(13) Clawson, Marion. Methods of Measuring the Demand for and Value of Outdoor Recreation. Reprint No. 10. Washington, D.C.: Resources for the Future, Inc., 1959.

(14) Clawson, Marion, and Jack L. Knetsch. Economics of Outdoor Recreation. Baltimore: The John Hopkins Press, 1966.

(15) Clawson, Marion, and Jack Knetsch. Outdoor Recreation Research: Some Concepts and Suggested Areas of Study. Reprint No. 43. Washington, D.C.: Resources for the Future, Inc., 1963.

(16) Corps of Engineers, Department of the Army. Recreation. Washington, D.C.: 1972 .

(17) Dauite, Robert J. "Methods for Determination of Demand for Outdoor Recreation." Land Economics, Vol. 42 (August, 1966), pp。237-238.

(18) Dolan, Edwin G。 TANSTAAFL: There Ain't No Such Thing As A Free Lunch. New York: Holt, Rinehart, and Winston, Inc., 1971 .

(19) Dutta, M。 Econometric Methods. Cincinnati, Ohio: South-Western Publishing Co., 1974.

(20) Farrar, Donald E, and Robert R. Glauber. "Multicollinearity in Regression Analysis: The Problem Revisited." Review of Economics and Statistics, Vol。49 (February, 1967), pp。92107 .

(21) Ferguson, C. E. Microeconomic Theory. Homewood, I17inois: Richard D. Irwin, Inc., 1972 .

(22) Friedman, Milton. Capitalism and Freedom. Chicago: The University of Chicago Press, 1962.

(23) Garbacz, Christopher. "The Ozarks: Recreation and Economic Development." Land Economics, Vol. 47 (November, 1971), pp.418-421.

(24) Gibbs, Kenneth C. "Evaluation of Outdoor Recreation Resources: A Note." Land Economics, Vo1. 50 (August, 1974), pp.309-311.

(25) Gibbs, Kenneth C. "Economics and Outdoor Recreation." Florida Food and Resource Economics, No. 4 (May-June, 1975), pp. T-4. 
(26) Gibbs, Kenneth C. and Richard J. Conner. "Components of Outdoor Recreational Values." Southern Journal of Agricultural Economics, Vol. 5 (July, 1973), pp. 239-244。

(27) Gillespie, Glenn A. and Durward Brewer. An Economic Model for Predicting Water-Oriented Outdoor Recreation Demand. Washington: U.S. Department of Agriculture, Economic Research Service, ERS-402, March, 1969.

(28) Goldin, Kenneth D. "Roads and Recreation." Land Economics, Vol. 49 (May, 1973), pp. 114-124.

(29) Harkin, Duncan A. "The Decision for Public or Private Ownership of Resources." Land Economics, Vo1. 48 (May, 1972), pp。 144-150.

(30) Harper, Robert A., Theodore H. Schmudde, and Frank H. Thomas. "Recreation Based Economic Development and the Growth Point Concept." Land Economics, Vo1. 42 (February, 1966), pp. 95101.

(31) Henderson, James M., and Richard E. Quandt. Microeconomic Theory: A Mathematical Approach. New York: McGraw. Hi11, 1971.

(32) Hinote, Hubert. Benefit-Cost Analys is for Water Resource Projects. Knoxville: Tennessee Valley Authority, 1967.

(33) Jaakson, Reiner. "Zoning to Regulate On-Water Recreation." Land Economics, Vol. 47 (November, 1971), pp. 382-388。

(34) Jennings, Thomas A., and Kenneth C. Gibbs. "Some Issues Concerning Specification and Interpretation of Outdoor Recreation Demand Models." Southern Journal of Agricultural Economics, Vol. 6 (Juiy, 1974), pp. 164-169。

(35) Johnston, J。 Econometric Methods. New York: McGraw Hi11, 1972.

(36) Kmenta, Jan. Elements of Econometrics. New York: The Macmillan Co., 1971.

(37) Knetsch, Jack L. "Interpreting Demands for Outdoor Recreation。" Economic Record, Vo1. 48 (September, 1972), pp. 429-432。

(38) Knetsch, Jack L. "Outdoor Recreation Demands and Benefits," Land Economics, Vol。39 (November, 1963), pp. 387-396.

(39) Leftwich, Richard $H$. The Price System and Resource Allocation. Hinsdale, I1linois: The Dryden Press, 1973.

(40) Mapp, Harry P. and Daniel D. Badger. "Input-Output Analys is of the Economic Impact of Outdoor Recreation in Southeastern 0klahoma." Oklahoma Current Farm Economics, Vol. 43, No. 2 (June, 1970), pp. 23-30. 
(41) Miller, William L., and Bruce A. Scherr. "Cost Sharing for Recreation: Efficiency and Equity." Land Economics, Vo1. 50 (February, 1974), pp. 58-65.

(42) Musgrave, Richard A. The Theory of Public Finance. New York: McGraw Hi11, 1959。

(43) National Water Commission. New Directions in U.S. Water Policy. Washington, D.C.: Government Printing Office, 1973.

(44) Outdoor Recreation Resources Review Commission. Outdoor Recreation for America, A Report to the President and to the Congress. Washington: Government Printing Office, 1962 .

(45) Pearse, Peter H. "A New Approach to the Evaluation of Non-Priced Recreation Resources." Land Economics, Vo1. 44 (February, 1968), pp.87-99.

(46) Ranken, R. L., and J. A. Sinden. "Causal Factors in the Demand for Outdoor Recreation:" Economic Record, Vo1. 47 (September, 1971), pp. 418-426.

(47) Rao, Potluri, and Roger LeRoy Miller. Applied Econometrics. Belmont, California: Wadsworth Publishing Co., Inc., 1971.

(48) Robinson, Warren C. "The Simple Economics of Public Outdoor Recreation。" Land Economics, Vo1.43 (February, 1967), pp. 71-83.

(49) Samuelson, Paul A. "Social Indifference Curves." The Quarterly Journal of Economics, Vo1. 70 (February, 1956), pp. 1-22。

(50) Seckler, David W. "On the Uses and Abuses of Economic Science in Evaluating Public Outdoor Recreation." Land Economics, Vo1. 42 (November, 1966), pp. 485-494.

(51) Steiner, Peter 0. Public Expenditure Budgeting. Washington, D.C.: The Brookings. Institute, 1969.

(52) Steiner, Peter 0. "The Public Sector and the Public Interest." in Public Expenditures and Policy Analys is by Haveman, Robert H., and Julius Margolis. Chicago: Markham, 1970.

(53) Thei1, Henri. Principles of Econometrics. New York: John Wiley and Sons, Inc., 1971.

(54) U.S. Congress. Senate Document No. 97. Policies, Standards, and Procedures in the Formulation, Evaluation, and Review of Plans for Use and Development of Water and ReTated Land Resources. Washington, D.C.: U.S. Government Printing Office, 1962 . 
(55) U.S. Department of the Army. Office of the Chief of Engineers. Regulation ER1130-2-404. "Recreation Use Fees." Washington, D.C.: 1974.

(56) U.S. Department of Commerce. Bureau of the Census. Census of Population, 1970, Characteristics of the Population, Oklahoma. Vo1.1, Part 38. Washington, D.C.: Government Printing Office, 1973.

(57) U.S. Statutes at Large. Public Law $\frac{88-29}{1965}$. Vo1. 78. "Land and Water Conservation Fund Act of 1965." Washington, D.C.: U.S. Government Printing Office, 1965, pp. 897-904。

(58) U.S. Statutes at Large. Public Law 89-72. Vo1. 79. "Federal Water Project Recreation Act." Washington, D.C.: U.S. Government Printing Office, 1966, pp. 213-218.

(59) U.S. Statutes at Large。 Pub7 ic Law 93-303. Vol. 88. "Amendment to Land and Water Conservation Fund Act of 1965." Washington, D.C.: U.S. Government Printing Office, 1973, pp. 1-4.

(60) Vickerman, R。W。 "The Evaluation of Benefits from Recreational Projects。" Urban Studies, Vo1. 11 (October, 1974), pp.277288.

(61) Walters, A. A. An Introduction to Econometrics. New York: Norton and Company, 1970 .

(62) Warner, Larkin, Danie1 D. Badger, and Gerald M. Lage, Impact Study of the Construction and Operation of the Tenkiller Ferry Lake, 0klahoma. Stillwater: 0klahoma State University Research Foundation, August, 1973.

(63) Water Resources Council. "Establishment of Principles and Standards for Planning." Federal Register. Washington, D.C., September 10, 1973.

(64) Wildavsky, Aaron. The Politics of the Budgeting Process. Boston: Little, Brown, and Co., 1964。 
APPENDIX A

SURVEY INSTRUMENT 
1974 MCCLILLLAN-KERR ARKANSAS RIVER SYSTEM WATERBASED RECREATION SURVFY

Department of Agricultural Economics

Oklahoma State University

Stillwater, Oklahoma 74074

Section 0 GENERAL INFORMATION

Lake or L\&D__ Date
Date_Interviewer

PUA Time A.M. Major Rec. Activity

Weather Data
(0.01) 1. Sunshine
2. Cloudy
3. Windy
4. Rain
$(0.02)$ 1. $\operatorname{Cool}\left(45-64^{\circ}\right)$
2. Warm $\left(65-84^{\circ}\right)$
3. Hot $\left(85+^{\circ}\right)$

Section 1 TRIP INFORMATION

(1.01) P1ace of Permanent Residence

City

County

State

(1.02) Mode of Travel

1. Car

5. Pick-up camper

9. Train

2. Car-tent trailer

6. Mobile camper

10. Bus

13. Other

3. Station wagon

7. Motorcycle

11. Private plan

4. Pick-up

8. Bicycle

12. Commercial Air

(1.03) Highway(s) used to enter the region

(1.04) Miles from home to this recreational area miles

(1.05) Driving time from home to this recreational area hours

(1.06) Is the purpose of this trip for recreational purposes only?

1. yes

2. no

3. if no, percent of time for recreation

(1.07) Is the purpose of this recreational trip primarily to use the recreational facilities at this public use area?

1. yes 2. no

(1.08) If answer is no in (1.07) what other places will you visit?

(1.09) If answer is no in (1.07), what other recreational activities will you participate in?

(1.10) Type of trip to the Lake or Lock and Dam (L\&D)

1. Less than 1 day 3. Overnight

2. 1 day 4 . More than 1 night no. of days and nights

(1.11) When did you arrive in this area (date and/or time of day)

(1.12) Did you spend last night enroute to this area
1. yes
2. no
3. if yes, which town or location

(1.13) Where do you plan to spend tonight

1. In this immediate recreational area (the PUA)

2. At another recreational area around this lake or L\&D

3. Within the region but away from the Lake or L\&D

4. Outside the region

(1.14)a. Type of overnight accomodations you plan to use tonight
1. Return home away from Lake
6. Seasonal home near Lake
2. Cabin on or near Lake
7. Permanent home near Lake
3. Motel on or near Lake
4. Camper vehicle on or near Lake
5. Tent on or near Lake
8. Stay with relatives near Lake
9. Stay with friends near Lake
10. Other
(Specify)

b. (Ask only if circle 6 or 7 on (1.14a) Do you own a seasonal or permanent home near or on this Lake 1 . yes 2 . no

c. (Ask only if yes on (1.14b) If own seasonal or permanent home near the Lake where is it located?

d. (Ask only if circled 6 or 7 on (1.14a) but no in (1.14b)

If do not own the seasonal or permanent home near the Lake, rent paid per month. 
(1.15) Have you visited other recreational areas AT THIS LAKE or L\&D today

$$
\begin{array}{lll}
1 . & \text { yes } & \text { no Where }
\end{array}
$$

(1.16) Have you visited other recreational areas AWAY FROM THIS LAKE or L\&D today

$$
\begin{array}{llll}
\text { 1. yes } 2 . & \text { no } & \text { 3. Where }
\end{array}
$$

(1.17) How many miles have you driven, or do you plan to drive, in this immediate (local) area for recreational purposes

(1.18) Highways plan to use to leave this region

(1.19) Have your travel plans to this area or to other recreational areas been affected by possible gasoline shortages

1. yes 2. no

If yes, please explain to what extent

Section 2 PERSONAL DATA FOR PERSON INTERVIEWED

(2.01) Sex: 1. male 2. female

(2.02) Age:

(2.03) Marital Status: 1. married 2. single 3. widow or widower 4. divorced

(2.04) Number of family members or others in recreational party by age (write in number)
1. $0-5$
4. $15-19$
5. $20-29$
7. 40-49
2. $6-10$
6. $30-39$
8. $50-5$
3. $11-14$

(2.05) Occupation:
1. professional
2. manager; administrator
3. sales; clerical
4. craftsman
5. laborer; operatives
7. farmer or farm worker
6. service worker
8. retired
9. not employed
10. other

(2.06) Typical or normal work week

hours days

(2.07) Education
1. $0-6$
4. 13-15
2. $7-11$
5. B.S.
7. Ph.D. or M.D.
8. Technical
3. 12 (High Schoo1) 6. M.S.
9. Other (specify)

(2.08) Total household income per year (note, household income includes income from all sources in the current year.)
1. under $\$ 3,000$
2. $\$ 3,000-4,999$
4. $\$ 7,000-8,999$
5. $\$ 9,000-11,999$
7. $\$ 15,000-19,999$
3. $\$ 5,000-6,999$
6. $\$ 12,000-14,999$
8. $\$ 20,000-29,999$
9. $\$ 30,000$ and over

(2.09) Weeks vacation you usually take per year

Section 3 RECREATION EXPENDITURES

(3.01) What are your anticipated total expenditures on this recreational trip for LODGING?

Item
$\begin{aligned} & \text { Motel, hotel, or cabin } \\ & \text { Rental, sleeping equip. } \\ & \text { (non-motorized) } \\ & \begin{array}{l}\text { Trailer or camper } \\ \text { Tent }\end{array}\end{aligned}$
$\begin{aligned} & \text { Camping fees, including } \\ & \text { electric hookups } \\ & \quad \begin{array}{l}\text { Public (gov't.) } \\ \text { Private }\end{array}\end{aligned}$
Other



(3.02) What are your anticipated total expenditures on this recreational trip for FOOD and
BEVERAGES?

\begin{tabular}{|c|c|c|c|}
\hline Item & Expenditures & $\begin{array}{l}\% \text { Purchased } \\
\text { in Region }\end{array}$ & $\begin{array}{l}\% \text { Purchased } \\
\text { Outside Region }\end{array}$ \\
\hline Brought from home & & & \\
\hline Purchased in restaurants & & & \\
\hline $\begin{array}{l}\text { Purchased from stores } \\
\text { (locally or enroute) }\end{array}$ & & & \\
\hline Charcoal, lighter fluid & & & \\
\hline Ice & & & \\
\hline Other & & & \\
\hline
\end{tabular}

Comments

(3.03) What are your anticipated total expenditures on this recreational trip for TRANSPORTATION?

Item $\quad$ Expenditures $\quad$ in Region $\quad \begin{gathered}\text { \% Purchased } \\ \text { in Rurchased }\end{gathered} \quad \begin{gathered}\text { \% Putside Region } \\ \text { Outs }\end{gathered}$

Gas and oil

Auto or vehicle repair

Vehicle rental

Commercial fares

(air, train, bus, etc.)

Tolls for turnpike travel

other

(specify)

Comments

(3.04) What are your anticipated total expenditures on this recreational trip for RECREATION related activities and supplies?

Item

Expenditures

Boat and/or motor rental

Boat gas \& oil

Boat launching and other

user fees (excluding camping

fees)

Amusements (putt-putt, horseshoes, golf, paddle boats, movies)

other (specify)
$\%$ Purchased in Region
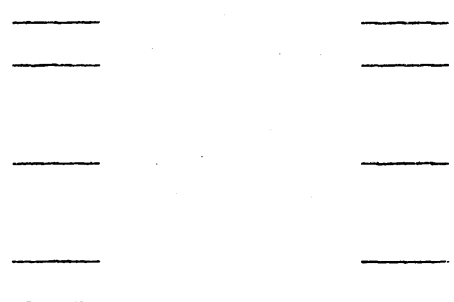

\% Purchased

Outside Region

Comments 
(3.05) What are your anticipated total expenditures on this recreational trip for OTHER items not included in $3.01,3.02,3.03$ and 3.04

Eifts
$\begin{aligned} & \text { Curios } \\ & \text { Insert reptilents, suntan } \\ & \text { lotions, chapstick } \\ & \text { Other }\end{aligned}$

(3.06) Times you engage in various water and related land-based recreational activities ANNUALLY

1. Boating

2. Fishing

3. Water skiing
4. Camping

5. Swimming

6. Other

(specify activity and no. of times)

(3.07) What are your ANNUAL average expenditures for RECREATION activities, supplies, and services

BOATING $\quad \begin{gathered}\text { Annual Average } \\ \text { Expenditures }\end{gathered}$

Boat repairs

Boat storigi

Inssurance

License \& Reg. Fees

uxiliary accessories

(].ights, preservers)

other

(pecify)

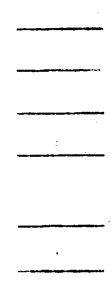

Annual Average

Expenditures

Buat services

(sed BOATING)

Rond and Reels

Fishing equipment and

supplies (tubes, waders,

tackle, !ures, bait)

Fishj:g licenses

lsning guides

Fis? ex" vg

other
$\%$ Purchased

in Region
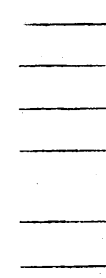

$\%$ Purchased

Outside Region

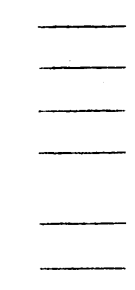

\% Purchased

in Region

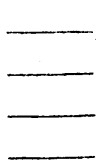

$\%$ Purchased Outside Region 


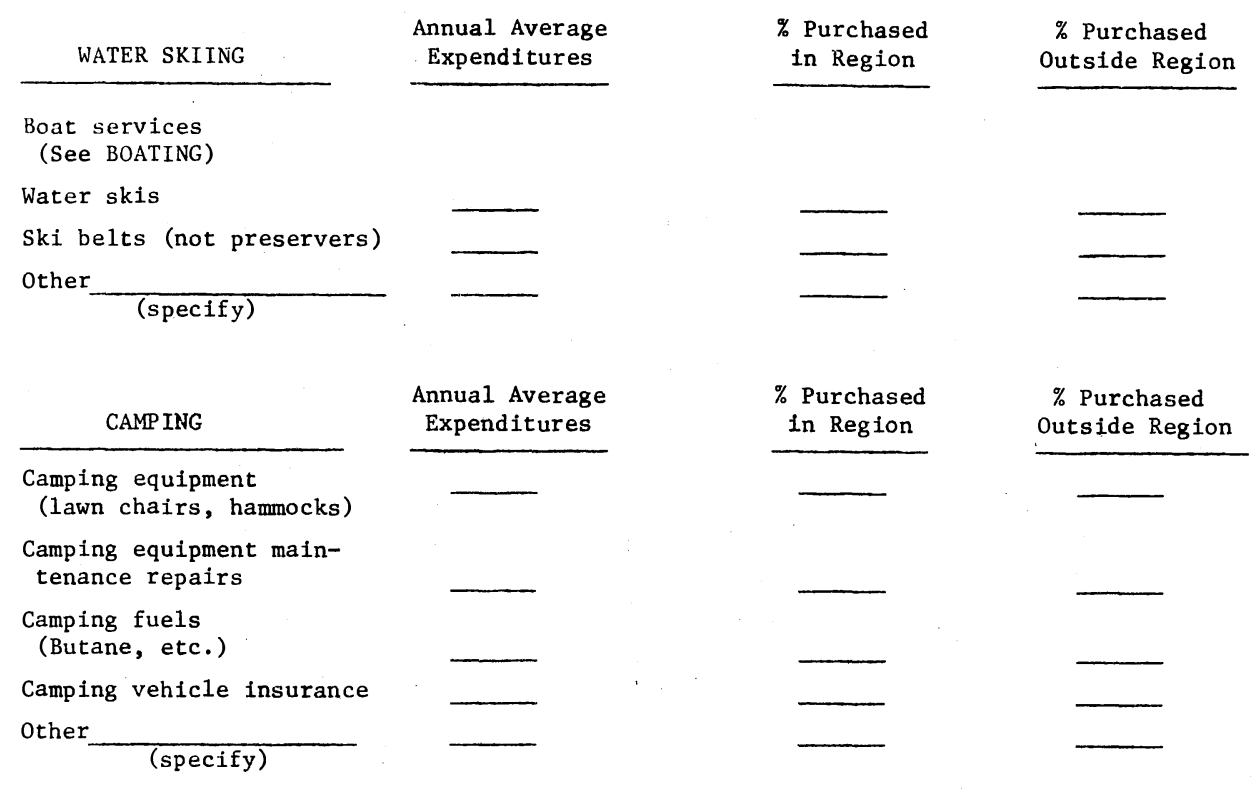

Section 4 RECREATIONAL EQUIPMENT INVENTORY

\begin{tabular}{|c|c|c|c|c|}
\hline & Item & Quantity & When Purchased & $\begin{array}{c}\text { City } \\
\text { Where Purchased } \\
\end{array}$ \\
\hline$(4.01)$ & Canoe (Length & & & \\
\hline$(4.02)$ & Boat (Length & & & \\
\hline$(4.03)$ & Motor ( H.P. $)$ & & & \\
\hline$(4.04)$ & Boat trailer & & & \\
\hline$(4.05)$ & Skiing Equipment & & & \\
\hline$(4.06)$ & Tent (Size $\quad x$ & & & \\
\hline$(4.07)$ & Camper Trailer(Length & & & \\
\hline$(4.08)$ & Tent Trailer (No. sleeps & & & \\
\hline$(4.09)$ & Pick-up camper (\% Rec.Use & & & \\
\hline$(4.10)$ & Motor Home (Length & $一$ & & \\
\hline$(4.11)$ & Bicycles (Type & & & \\
\hline$(4.12)$ & Minibikes (\% rec. use & & & \\
\hline$(4.13)$ & Motorcycles (\% rec. use & & & \\
\hline$(4.14)$ & Other & & & \\
\hline$(4.15)$ & Other & & & \\
\hline
\end{tabular}

Section 5 BOAT AND TRAILER STORAGE

(5.01) Where is boat stored or parked when not being used for recreation

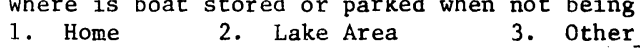
(specify where)

(5.02) Cost of Boat Storage (monthly rate)

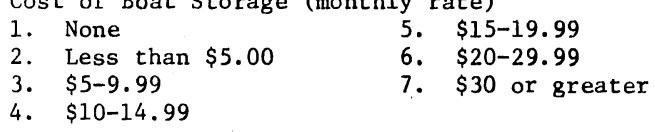


(5.03) Where is Camper trailer or camping vehicle stored or parked when not being used for recreation

1. Home

2. Lake Area

3. Other (specify where)

(5.04) Cost of Camper Trailer Storage (monthly rate)
1. None
5. $\$ 15-19.99$
$6 . \quad \$ 20-29.99$
2. Less than $\$ 5.00$
3. $\$ 5-9.99$
7. $\$ 30$ or greater

4. $\$ 10-14.99$

How is the trailer storage rental rate determined

Section 6 SITE PREFERENCES AND OPINIONS

(6.01) Why did you select this SITE for your recreation visit
1. Close to home
5. Flush tollets
6. Boat dock or marina 10 . Nearby attractions
9. Attractive area
2. Visited this area before
3. Recommended by friend
7. Boat launching ramp
tearby attractions

4. Electric outlets

8. Trailer dump station 12. Other

(6.02) How did you first learn about the facilities at this site

1. T.V. (Advertising, outdoor program, etc.) 6. Road Map

2. Radio (Advertising, outdoor program, etc.) 7. Boat and Travel Show

3. Newspaper

4. Travel Magazine

5. Travel Association Directories

8. Relative

9. Friend

10. Other

(6.03) Indicate the type of public facilities used at this recreational area during this trip

1. Picnic table 8. Boat Launching ramp

2. Gril1

3. Picnic shelter

4. Trash barre1

5. Tollet

6. Shower

7. Campsite

9. Nature trail

10. Drinking water

11. Electric hookups

12. Trailer sanitary station

13. Playground

14. Other

(6.04) What would you like to see done to improve this recreation area?

1. More boat launching ramps 5. More access roads 9. Pull through sites

2. More camping sites 6. Flush toilets

3. More swimming areas 7. Showers

4. Improve fish management 8. Dump station

10. Electric outlets

11. Other

12. Other

(6.05) Which of the following do you consider to be problems at the lake site?

1. Littering

2. Insufficient trash collection and/or trash facilities

3. Dirty toilet facilities

4. Maintenance of grassed areas

5. Noise problems due to land vehicles

6. Safety problems due to fast traffic

7. Dust from roads

8. Insufficient security patrol

9. Other

(6.06) From the list in (6.05), indicate the one problem you consider to be the most important. (write in number from (6.05))

(6.07) Does water elevation influence your use of the lake recreational facilities? 1. yes 2. no

If yes comment on how

(6.08) (Only for those persons who use Corps of Engineers NON FEE Camping areas). Would you be willing to pay a nominal user fee if this fee would be used for maintenance and improvement of the facilities?

1. yes

2. no

Comments 
(6.09) (Only for those persons using Corps of Engineers FEE camping areas.) Do you object to paying the fee for the camping site you are occupying?

1. yes

2. no

Comments

Section 7 FREQUENCY AND DISTRIBUTION OF VISITS TO THIS LAKE OR L\&D DURING THE YEAR

(7.01) Are you a frequent user of this Lake or L\&D
1. yes
2. no

(7.02) If yes, when did you first use this Lake or L\&D?
0. 1974
1. 1973
6. 1968
1972
7. 1967
8.1966
3. 1971
4. 1970
9. 1965
10. Before 1965

5. 1969

In the table below $f 111$ in the blanks by indicating the number of visits to this Lake or L\&D for the period listed on the left. Complete the second column by indicating the average length of visit for trips in each period.

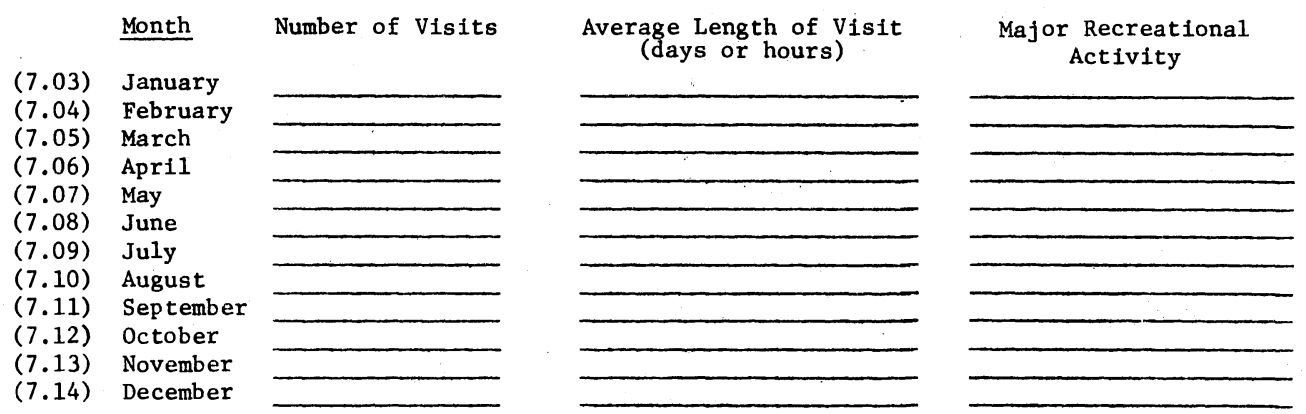

(7.15) What is the major factor which limits the time you spend recreating at this lake?

1. Time

2. Money

3. Distance from home

GENERAL COMMENTS
4. Crowding in recreation area

5. Other (specify) 
APPENDIX B

DATA 
DATA

This appendix contains the basic cross-section data used in the regression analysis. Table XXXI contains the data from Tenkiller Lake; Table XXXII contains the data from Fort Gibson Lake; and Table XXXIII contains the data from Eufaula Lake. The columns are labeled OBS, R, $P_{1}, P_{2}, P_{3}, D_{4}, D_{5}, D_{6}$, and $D_{7}$ respectively. $O B S$ is the observation number; $R$ is visitor days per group for the four month study period; $P_{1}$ is price per visitor day; $P_{2}$ is price at alternative lake $1 ; P_{3}$ is price at alternative lake $2 ; D_{4}, D_{5}$ and $D_{6}$ are dummy variables for income; and $\mathrm{D}_{7}$ is an intercept dummy which distinguishes between fee and non-fee area recreationists. Complete empirical definitions of these variables are given in Chapter III. 
TABLE XXXI

REGRESSION ANALYSIS DATA: TENKILLER LAKE

\begin{tabular}{|c|c|c|c|c|c|c|c|c|}
\hline OBS & $R$ & Pl & P2 & P3 & 04 & D5 & D6 & D7 \\
\hline 1 & 56.0 & 1.2500 & 11.600 & 24.000 & 0 & 1 & 0 & 1 \\
\hline 2 & 392.0 & 0.8333 & 20.385 & 23.615 & 0 & 0 & 0 & 1 \\
\hline 3 & 10.0 & 3.5313 & 12.461 & 11.152 & 0 & 1 & 0 & 1 \\
\hline 4 & 48.0 & 2.4583 & 18.615 & 21.859 & 0 & 0 & 0 & 0 \\
\hline 5 & 30.0 & 2.2667 & 48.750 & 53.000 & 1 & 0 & 0 & 1 \\
\hline 6 & 6.0 & 7.7778 & 18.362 & 20.190 & 0 & 0 & 0 & 0 \\
\hline 7 & 10.0 & 2.7750 & 51.827 & 60.147 & 0 & 0 & 0 & 0 \\
\hline 8 & 16.0 & 1.3281 & 15.540 & 18.900 & 0 & 0 & 0 & 0 \\
\hline 9 & 15.0 & 3.0000 & 37.385 & 48.462 & 0 & 0 & 0 & 0 \\
\hline 10 & 35.0 & 14.2857 & 450.000 & 558.000 & 0 & 0 & 0 & 0 \\
\hline 11 & 60.0 & 1.3333 & 52.941 & 49.129 & 0 & 0 & 1 & 1 \\
\hline 12 & 56.0 & 1.5179 & 43.118 & 40.215 & 0 & 0 & 0 & 1 \\
\hline 13 & 112.0 & 0.2857 & 22.640 & 26.000 & 0 & 0 & 0 & 0 \\
\hline 14 & 60.0 & 1.8750 & 19.000 & 19.250 & 0 & 0 & 0 & 1 \\
\hline 15 & 120.0 & 0.6857 & 12.833 & 12. 833 & 0 & 1 & 0 & 1 \\
\hline 10 & 38.0 & 2.3000 & 18.954 & 18.954 & 0 & 1 & 0 & 1 \\
\hline 17 & 30.0 & 1.2222 & 10.636 & 10.727 & 1 & 0 & 0 & 1 \\
\hline 18 & 39.0 & 2.1667 & 14.300 & 16.792 & 0 & 1 & 0 & 0 \\
\hline 19 & 14.0 & 2.8750 & 31.724 & 27.069 & 0 & 0 & 1 & 1 \\
\hline 20 & 15.0 & 1.5333 & 19.900 & 15.300 & 0 & 0 & 1 & 0 \\
\hline 21 & 60.0 & 2.2619 & 82.300 & 82.200 & 0 & 1 & 0 & 1 \\
\hline 22 & 8.0 & 1.0000 & 4.192 & 5.536 & 1 & 0 & 0 & 0 \\
\hline 23 & 16.0 & 0.6250 & 11.480 & 5.180 & 0 & 0 & 1 & 1 \\
\hline 24 & 30.0 & 0.8214 & 9.647 & 4. 353 & 0 & 0 & 1 & 0 \\
\hline 25 & 120.0 & 0.7333 & 13.714 & 13.714 & 0 & 1 & 0 & 0 \\
\hline 26 & 21.0 & 1.9452 & 44.645 & 38.710 & 0 & 0 & 1 & 0 \\
\hline 27 & 42.0 & 2.2500 & 84.735 & 73.469 & 0 & 0 & 0 & 1 \\
\hline 28 & 84.0 & 0.7857 & 61.059 & 52.941 & 0 & 0 & 1 & 0 \\
\hline 29 & 22.5 & 0.9286 & 50.882 & 44.118 & 0 & 0 & 1 & 0 \\
\hline 30 & 4.0 & 1.8750 & 9.183 & 7.928 & 1 & 0 & 0 & 0 \\
\hline 31 & 90.0 & 0.9722 & 44.906 & 47.071 & 1 & 0 & 0 & 1 \\
\hline 32 & 126.0 & 0.4762 & 22.500 & 19.800 & 0 & 0 & 0 & 0 \\
\hline 33 & 4.0 & 2.6250 & 6.240 & 4.640 & 0 & 0 & 1 & 0 \\
\hline 34 & 72.0 & 3.6667 & 15.620 & 14.850 & 1 & 0 & 0 & 0 \\
\hline 35 & 35.0 & 0.7000 & 24.097 & 22.909 & 0 & 0 & 1 & 0 \\
\hline 36 & $21 \cdot 0$ & 0.7619 & 13.867 & 10.819 & 0 & 0 & 1 & 0 \\
\hline 37 & 28.0 & I. 5357 & 16.660 & 19.040 & 0 & 0 & 0 & 1 \\
\hline 38 & 12.0 & 1.9167 & 11.200 & 7.800 & 0 & 0 & 1 & 1 \\
\hline 39 & 144.0 & 1.0000 & 17.500 & 18.750 & 1 & 0 & 0 & 0 \\
\hline 40 & 14.0 & 2.3750 & 2.222 & 7.111 & 0 & 1 & 0 & 1 \\
\hline 41 & 8.0 & 4.9375 & 29.167 & 34.767 & 0 & 0 & 1 & 0 \\
\hline 42 & 42.0 & 2.5000 & 8.000 & 13.333 & 0 & 1 & 0 & 1 \\
\hline 43 & 4.0 & 1.3750 & 5.250 & 8.750 & 1 & 0 & 0 & 0 \\
\hline 44 & 66.0 & 0.0111 & 8.000 & 13.333 & 0 & 0 & 1 & 1 \\
\hline 45 & 48.0 & 2.1667 & 8.727 & 14.545 & 0 & 0 & 0 & 0 \\
\hline 46 & 24.0 & 1.4762 & 12.000 & 20.000 & 0 & 1 & 0 & 1 \\
\hline 47 & 124.0 & 0.7083 & 4.800 & 8.000 & 0 & $i$ & 0 & 0 \\
\hline 48 & 216.0 & 0.8889 & 27.067 & 28.444 & 1 & 0 & 0 & 0 \\
\hline 49 & 30.0 & 4.3750 & 13.091 & 21.818 & 0 & 0 & 1 & 1 \\
\hline 50 & 144.0 & 0.4125 & 1.265 & 2.109 & 0 & 0 & 1 & 0 \\
\hline 51 & 8.0 & 2.1875 & 12.000 & 20.000 & 0 & 0 & 0 & 1 \\
\hline 52 & 40.0 & 1.0893 & 23.667 & 7.000 & 1 & 0 & 0 & 1 \\
\hline 53 & 14.0 & 2.6429 & 21.000 & 24.600 & 0 & 1 & 0 & 1 \\
\hline 54 & 99.0 & 0.9524 & 22.105 & 25.895 & 0 & 0 & 0 & 0 \\
\hline 55 & 155.0 & 0.7258 & 50.909 & 59.636 & 0 & 0 & 1 & 0 \\
\hline
\end{tabular}


TABLE XXXI (Continued)

\begin{tabular}{|c|c|c|c|c|c|c|c|c|}
\hline$\overline{O B S}$ & $R$ & PI & P2 & P3 & 04 & 05 & D6 & 07 \\
\hline 56 & 42.00 & 0.5952 & 17.794 & 21.1765 & 0 & 0 & 0 & 0 \\
\hline 57 & 9.00 & 2.2222 & 14.405 & 17.1429 & 0 & 0 & 0 & 0 \\
\hline 58 & 35.00 & 0.6857 & 13.333 & 43.7333 & 1 & 0 & 0 & 1 \\
\hline 59 & 6.00 & 8.6444 & 80.294 & 58.6765 & 0 & 0 & 1 & 0 \\
\hline 60 & 36.00 & 1.1321 & 36.400 & 26.6000 & 0 & 1 & 0 & 0 \\
\hline 61 & 20.00 & 2.5000 & 23.036 & 27.1429 & 0 & 1 & 0 & 1 \\
\hline 02 & 48.00 & 0.7500 & 10.000 & 10.0000 & 0 & $\overline{0}$ & 0 & 0 \\
\hline 63 & 126.00 & 0.6667 & 8.000 & 8.0000 & 0 & 0 & 0 & 0 \\
\hline 64 & 64.00 & 1.2500 & 44.444 & 44.4444 & 0 & 0 & 0 & 0 \\
\hline 65 & 48.00 & 1.5000 & 9.600 & 9.6000 & 0 & 0 & 0 & 1 \\
\hline 66 & 30.00 & 1.7500 & 8.000 & 8.0000 & 0 & 0 & 1 & 0 \\
\hline 67 & 36.00 & 3.0833 & 40.000 & 40.0000 & 0 & 0 & 0 & 1 \\
\hline 68 & 8.00 & 1.8750 & 12.069 & 14.1379 & 0 & 1 & 0 & 0 \\
\hline 69 & 187.00 & 0.3896 & 19.516 & 23.2258 & 0 & 0 & 0 & 1 \\
\hline 70 & 252.00 & 1.2500 & 30.250 & 36.0000 & 0 & 0 & 1 & 1 \\
\hline 71 & 30.00 & 1.3333 & 17.826 & 21.9130 & 1 & 0 & 0 & 0 \\
\hline 72 & 96.00 & 0.8333 & 4.167 & 13.6667 & 1 & 0 & 0 & 0 \\
\hline 73 & 112.00 & 1.2500 & 6.000 & 19.6800 & $i$ & 0 & 0 & 0 \\
\hline 74 & 102.00 & 2.1667 & 10.000 & 32.8000 & 0 & 0 & 1 & 1 \\
\hline 75 & 101.25 & 1.2222 & 7.500 & 24.6000 & 0 & 0 & 0 & 1 \\
\hline 76 & 25.00 & 2.6000 & 45.500 & 33.2500 & 0 & 0 & 0 & 1 \\
\hline 77 & 45.00 & 2.0000 & 22.750 & 16.6250 & 0 & 0 & 1 & $i$ \\
\hline 78 & 16.00 & 0.8750 & 12.740 & 9.3100 & 0 & 0 & $i$ & 0 \\
\hline 79 & 21.00 & 1.2857 & 16.683 & 12.1917 & 0 & 0 & 0 & 1 \\
\hline 80 & 180.00 & 0.5571 & 12.727 & 7.8182 & 0 & 0 & 0 & 0 \\
\hline 81 & 36.00 & 1.1889 & 13.176 & 8.0941 & 0 & 1 & 0 & 1 \\
\hline 82 & 16.00 & 2.0708 & 16.471 & 10.1176 & 0 & 0 & 1 & 1 \\
\hline 83 & 56.00 & 1.4762 & 16.867 & 10.3614 & 0 & 0 & 0 & 1 \\
\hline 84 & 60.00 & 0.6576 & 9.545 & 5.8636 & 0 & 1 & 0 & $i$ \\
\hline 85 & 72.00 & 1.1167 & 4.375 & 2.6875 & 0 & 1 & 0 & 0 \\
\hline 86 & 35.00 & 1.0714 & 12.353 & 7.5882 & 0 & 0 & 0 & 0 \\
\hline 87 & 18.00 & 2.2500 & 7.412 & 4.5529 & 0 & 0 & 1 & 0 \\
\hline 88 & 28.00 & 2.7143 & 41.176 & 25.2941 & 0 & 0 & 0 & 0 \\
\hline 89 & 88.00 & 2.0000 & 22.105 & 13.5789 & 0 & 0 & 0 & 0 \\
\hline 90 & 63.00 & 1.2381 & 10.348 & 6.3565 & 0 & 0 & 0 & 1 \\
\hline 91 & 26.00 & 2.5000 & 11.667 & 7.1667 & 0 & 1 & 0 & 0 \\
\hline 92 & 54.00 & 3.8667 & 14.824 & 9.1059 & 0 & 0 & 1 & 0 \\
\hline 93 & 96.00 & 1.7500 & 5.000 & 3.0714 & 1 & 0 & 0 & 0 \\
\hline 94 & 56.00 & 2.2500 & 7.000 & 4.3000 & 0 & 0 & 0 & 0 \\
\hline 95 & 150.00 & 2.3500 & 17.500 & 10.7500 & 0 & 0 & 1 & 0 \\
\hline 96 & 108.00 & 1.1667 & 14.000 & 8.6000 & 0 & 0 & 0 & 1 \\
\hline 97 & 16.00 & 1.6667 & 7.000 & 4. 3000 & 1 & 0 & 0 & 0 \\
\hline 98 & 32.00 & 1.1781 & 11.200 & 6.8800 & 0 & 1 & 0 & 1 \\
\hline 99 & 168.00 & 1.4893 & 14.583 & 8.9583 & 0 & 0 & 0 & $i$ \\
\hline 100 & 30.00 & 1.5000 & 15.000 & 9. 2143 & 0 & 1 & 0 & 0 \\
\hline 101 & 66.00 & 1.9500 & 9.589 & 5.8904 & 0 & 0 & 0 & 0 \\
\hline 102 & 12.00 & 2.0833 & 8.750 & 5.3750 & 1 & 0 & 0 & 0 \\
\hline 103 & 90.00 & 3.7059 & 16.471 & 10.1176 & 0 & 0 & 0 & 0 \\
\hline 104 & 108.00 & 0.6687 & 5.000 & 3.0714 & 0 & 0 & 1 & 0 \\
\hline 105 & 36.00 & 15.8333 & 105.000 & 64.5000 & 0 & 0 & 0 & 1 \\
\hline 106 & 18.00 & 0.8917 & 0.650 & 4.0850 & 1 & 0 & 0 & 0 \\
\hline 107 & 42.00 & 1.2738 & 17.500 & 10.7500 & 0 & 0 & 0 & 1 \\
\hline 108 & 42.00 & 1.0000 & 20.000 & 12.2857 & 1 & 0 & 0 & 0 \\
\hline 109 & 30.00 & 4.8333 & 10.938 & 6.7188 & 0 & 1 & 0 & 0 \\
\hline 110 & 36.00 & 1.3708 & 17.500 & 10.7500 & 0 & 0 & 0 & 0 \\
\hline
\end{tabular}


TABLE XXXI (Continued)

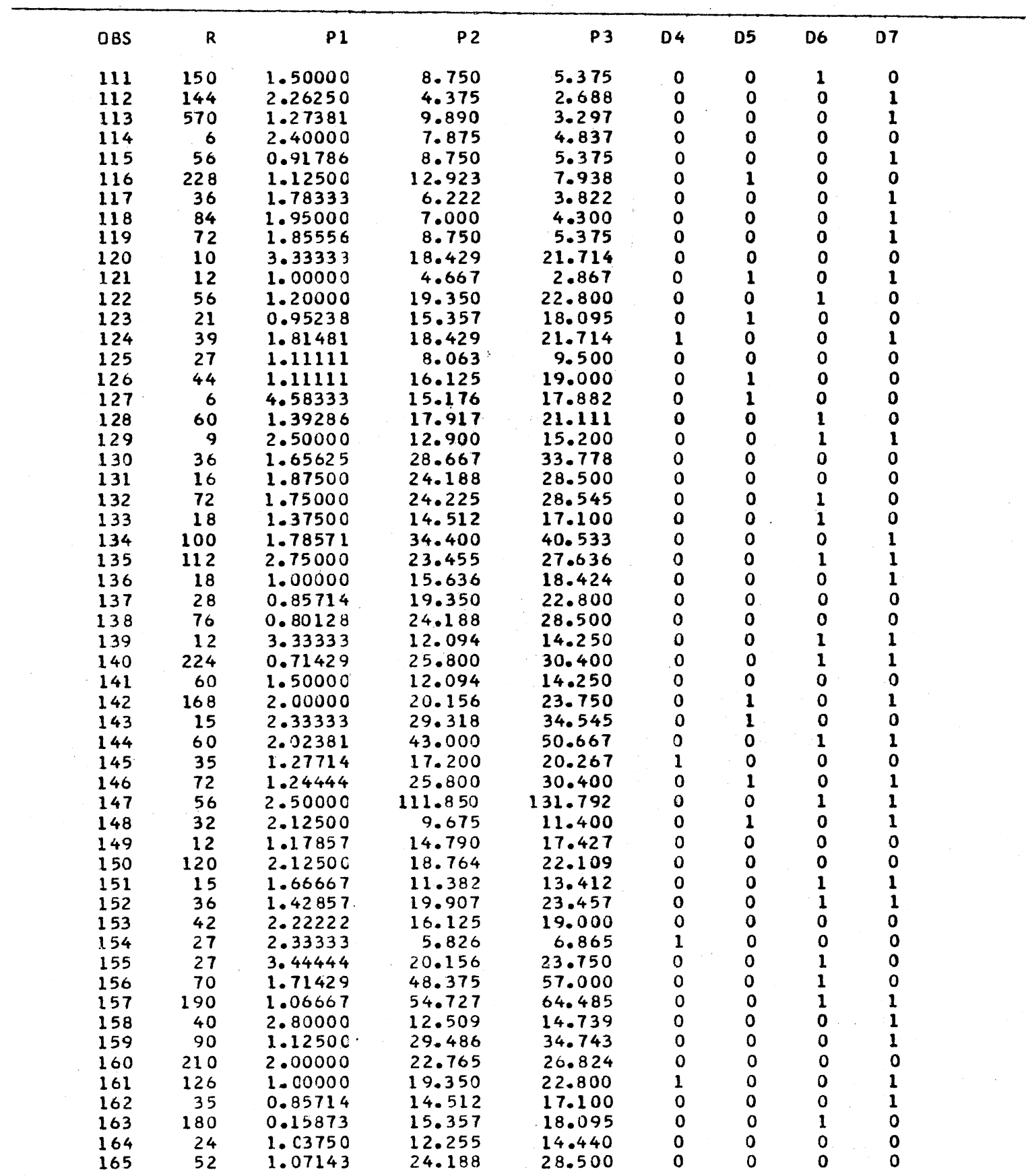


TABLE XXXI (Continued)

\begin{tabular}{|c|c|c|c|c|c|c|c|c|}
\hline OB S & $R$ & P1 & P2 & P3 & D4 & D5 & D6 & D7 \\
\hline 166 & 114.0 & 1.35417 & 12.900 & 15.200 & 0 & 0 & 0 & 1 \\
\hline 107 & 80.0 & 2.75000 & 19.350 & 22.800 & 0 & 0 & 1 & 1 \\
\hline 168 & 8.0 & 2.12500 & 13.291 & 15.661 & 0 & 1 & 0 & 0 \\
\hline 169 & 32.0 & 1.09375 & 12.094 & 14.250 & 0 & 0 & 0 & 0 \\
\hline 170 & 14.0 & 3.40000 & 13.222 & 11.000 & 0 & 0 & 1 & 1 \\
\hline 171 & 16.0 & 1.12143 & 12.000 & 9.300 & 0 & 1 & 0 & $i$ \\
\hline 172 & 140.0 & 0.50000 & 34.909 & 25. 091 & 0 & 0 & 1 & $i$ \\
\hline 173 & 8.0 & 1.25000 & 6.000 & 6.625 & 1 & 0 & 0 & 0 \\
\hline 174 & 12.0 & 0.54167 & 7.886 & 7.886 & 0 & 0 & 1 & 1 \\
\hline 175 & 10.0 & 0.35000 & 8.633 & 8.633 & 0 & 0 & 1 & 0 \\
\hline 176 & 18.0 & 0.55556 & 9.263 & 5.684 & 1 & 0 & 0 & 0 \\
\hline 177 & 84.0 & 1.28571 & 19.059 & 28.853 & 1 & 0 & 0 & 0 \\
\hline 178 & 56.0 & 0.53571 & 28.800 & 22.320 & $i$ & 0 & 0 & 0 \\
\hline 179 & 21.0 & 1.11111 & 30.000 & 23.250 & 1 & 0 & 0 & 0 \\
\hline 180 & 70.0 & 0.87143 & 60.800 & 68.800 & 0 & 0 & 0 & 1 \\
\hline 81 & 24.0 & 2.70833 & 21.120 & 13.640 & 0 & 0 & 1 & 0 \\
\hline 182 & 119.0 & 3.41134 & 365.690 & 302.148 & 0 & 0 & 1 & 0 \\
\hline 183 & 56.0 & 1.05000 & 17.455 & 17.455 & 0 & 0 & 0 & 1 \\
\hline 184 & 30.0 & 1.30000 & 7.820 & 13.340 & 1 & 0 & 0 & 1 \\
\hline 185 & 4.0 & 6.66667 & 28.000 & 31.684 & 0 & 1 & 0 & $i$ \\
\hline 180 & 50.0 & 1.20000 & 32.936 & 38.809 & 0 & 0 & 0 & 0 \\
\hline 187 & 14.0 & 4.46429 & 37.620 & 41.760 & 0 & 0 & 0 & 1 \\
\hline 188 & 98.0 & 0.64898 & 30.380 & 33.600 & 0 & 0 & 1 & 1 \\
\hline 189 & 112.0 & 1.40000 & 22.389 & 26.350 & 0 & 0 & 0 & 1 \\
\hline 190 & 28.0 & 1.61607 & 25.822 & 23.026 & 0 & 0 & 0 & $i$ \\
\hline 191 & 72.0 & 0.22727 & 14.000 & 13.500 & 0 & 0 & 0 & 0 \\
\hline 192 & 18.0 & 3.03125 & 9.450 & 11.812 & 0 & 0 & 0 & 1 \\
\hline 193 & 84.0 & 0.61224 & 23.550 & 21.000 & 1 & 0 & 0 & 0 \\
\hline 194 & 56.0 & 1.75000 & $31 \cdot 350$ & 24.000 & 1 & 0 & 0 & 1 \\
\hline 195 & 52.5 & 0.65714 & 24.267 & 13.333 & 0 & 0 & 0 & 1 \\
\hline 196 & 72.0 & 0.98214 & 14.787 & 9.100 & 0 & 0 & 0 & 0 \\
\hline 197 & 56.0 & 1.21429 & 20.100 & 15.200 & 0 & 0 & 0 & 0 \\
\hline 198 & 6.0 & 9.86667 & 56.400 & 46.600 & 0 & 0 & 0 & 1 \\
\hline 199 & 14.0. & 1.48214 & 15.200 & 2.000 & 1 & 0 & 0 & i \\
\hline 200 & 16.0 & 0.83333 & 16.706 & 4.941 & 0 & 1 & 0 & 1 \\
\hline 201 & 18.0 & 1.66667 & 21.111 & 21.111 & 0 & 0 & 0 & 0 \\
\hline 202 & 64.0 & 0.58333 & 3.800 & 3.800 & 0 & 0 & 1 & 0 \\
\hline 203 & $21 \cdot 0$ & 4.18750 & 47.590 & 39.029 & 0. & 0 & 0 & 0 \\
\hline 204 & 12.0 & 0.41667 & 3.750 & 1.250 & 0 & 0 & 0 & 0 \\
\hline 205 & 40.0 & 1.33929 & 15.000 & 5.000 & 0 & 0 & 1 & 1 \\
\hline 206 & 105.0 & 0.65714 & 6.600 & 3.300 & 0 & 1 & 0 & 0 \\
\hline $2 \cup 7$ & 50.0 & 0.70000 & 34.700 & 29.900 & 0 & 0 & 0 & 0 \\
\hline 208 & 42.0 & 1.25000 & 11.125 & 15.250 & 0 & 1 & 0 & 1 \\
\hline 209 & 77.0 & 1.36364 & 32.963 & 45.185 & 0 & 0 & 1 & $i$ \\
\hline 210 & 49.0 & 0.32653 & 11.392 & 15.616 & 0 & 0 & $i$ & 0 \\
\hline 211 & 416.0 & 0.92500 & 11.400 & 11.400 & 0 & 0 & $i$ & 0 \\
\hline 212 & 35.0 & C. 91429 & 12.400 & 11.600 & 0 & 0 & 1 & 1 \\
\hline 213 & 112.0 & 0.84821 & 16.750 & 8.500 & 0 & 1 & 0 & 0 \\
\hline 214 & 198.0 & 0.88889 & 22.182 & 17.273 & 0 & 1 & 0 & 1 \\
\hline 215 & 56.0 & 1.07143 & 15.529 & 9.529 & 1 & 0 & 0 & 0 \\
\hline 216 & 336.0 & 1.52381 & 55.200 & 68.800 & 0 & 0 & 0 & 1 \\
\hline 217 & 45.0 & 1.33333 & 18.857 & 15.000 & 1 & 0 & 0 & 0 \\
\hline 218 & 130.0 & 0.85000 & 5.000 & 7.800 & 0 & 1 & 0 & 0 \\
\hline 219 & 21.0 & 2.12500 & 8.160 & 9.010 & 0 & 0 & 1 & 0 \\
\hline 220 & 84.0 & 2.82540 & 39.383 & 36.392 & 0 & 1 & 0 & 1 \\
\hline
\end{tabular}


TABLE XXXI (Continued)

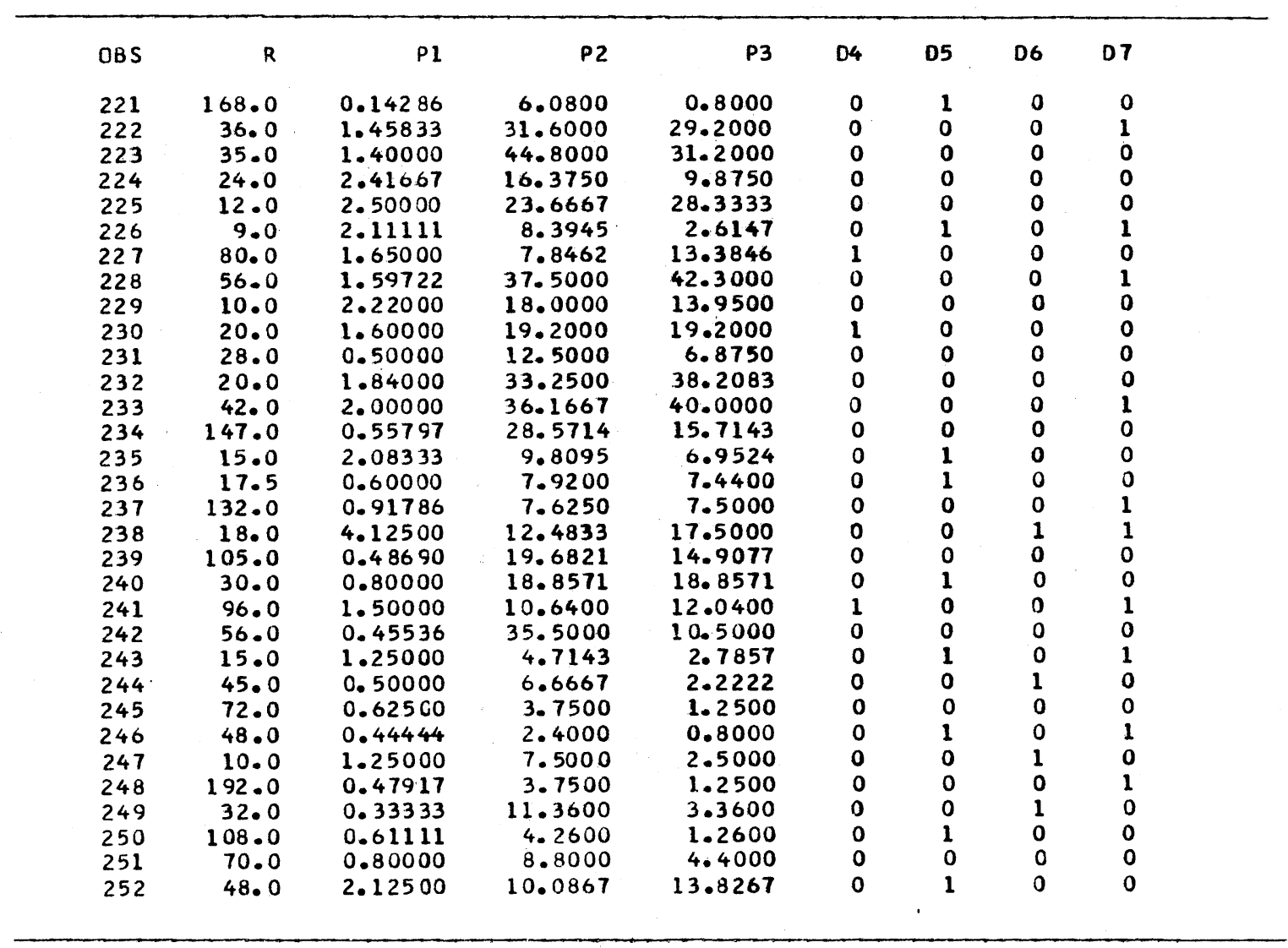


TABLE XXXII

REGRESSION ANALYSIS DATA: FORT GIBSON LAKE

\begin{tabular}{|c|c|c|c|c|c|c|c|c|}
\hline OBS & $R$ & P1 & P2 & P3 & D4 & 05 & D6 & 07 \\
\hline 1 & 120 & 0.4000 & 4.360 & 3.520 & 0 & 0 & 0 & 0 \\
\hline 2 & 14 & 0.9643 & 5.750 & 4.167 & 0 & 0 & 0 & 0 \\
\hline 3 & 18 & 1.1667 & 3.625 & 3.188 & 0 & 1 & 0 & 0 \\
\hline 4 & 36 & 0.5000 & 2.000 & 2.067 & 0 & 0 & 1 & 0 \\
\hline 5 & 6 & 1.6667 & 11.698 & 10.660 & 1 & 0 & 0 & 1 \\
\hline 6 & 36 & 1.6667 & 7.333 & 8.250 & 0 & 0 & 1 & 1 \\
\hline 7 & 45 & 0.6667 & 11.000 & 7.222 & 0 & 0 & 0 & i \\
\hline 8 & 36 & 1.6667 & 10.283 & 9.623 & 0 & 0 & 0 & 1 \\
\hline 9 & 16 & 5.5000 & 32.267 & 26.400 & 0 & 1 & 0 & 1 \\
\hline 10 & 24 & 1.5000 & 7.000 & 8.800 & 1 & 0 & 0 & $i$ \\
\hline 11 & 48 & 0.7500 & 6.364 & 8.000 & 0 & 0 & 0 & 1 \\
\hline 12 & 52 & 0.6071 & 7.778 & 9.778 & 0 & 0 & 1 & 1 \\
\hline 13 & 72 & 0.7500 & 12.375 & 8.125 & 0 & 0 & 0 & 1 \\
\hline 14 & 60 & 1.3194 & 7.000 & 8.800 & 0 & 0 & 1 & 1 \\
\hline 15 & 108 & 1.0556 & 5.250 & 0.600 & 0 & 0 & 1 & 1 \\
\hline 16 & 28 & 1.0714 & 2.800 & 3.520 & 1 & 0 & 0 & 0 \\
\hline 17 & 36 & 1.0714 & 8.250 & 9.281 & 1 & 0 & 0 & 0 \\
\hline 18 & 96 & 0.0694 & 8.750 & 11.000 & 0 & 0 & 0 & 0 \\
\hline 19 & 288 & 0.1667 & 2.143 & 2.214 & 0 & 0 & 0 & 0 \\
\hline 20 & 42 & 0.9524 & 19.000 & 18.625 & 1 & 0 & 0 & 0 \\
\hline 21 & 72 & 0.3125 & 3.750 & 3.875 & 0 & 0 & 1 & 0 \\
\hline 22 & 49 & 0.3673 & 13.680 & 7.800 & 0 & 0 & 1 & 1 \\
\hline 23 & 45 & 3.2700 & 166.500 & 166.500 & 0 & 0 & 0 & 0 \\
\hline 24 & 28 & 2.3661 & 59.750 & 5.5 .875 & 0 & 0 & 1 & 1 \\
\hline 25 & 24 & 1.5000 & 5.833 & 7.333 & 0 & 0 & 0 & 1 \\
\hline 26 & 30 & 1.3333 & 12.000 & 9.375 & 0 & 0 & 1 & 0 \\
\hline 27 & 54 & 2.0000 & 20.571 & 16.071 & 0 & 0 & 1 & 0 \\
\hline 28 & 24 & 0.5000 & 5.600 & 7.040 & 0 & 0 & 0 & 1 \\
\hline 29 & 18 & 1.1667 & 7.609 & 9.565 & 0 & 0 & 1 & 1 \\
\hline 30 & 84 & 0.5000 & 9.083 & 8.500 & 0 & 0 & 0 & 0 \\
\hline 31 & 42 & 1.3333 & 9.900 & 6.500 & 1 & 0 & 0 & 0 \\
\hline 32 & 108 & 1.6067 & 14.400 & 16.800 & 1 & 0 & 0 & 1 \\
\hline 33 & 48 & 2.2500 & 1. 5.695 & 10.305 & 0 & 0 & 0 & 1 \\
\hline 34 & 196 & 0.4688 & 11.000 & 12.375 & 1 & 0 & 0 & 1 \\
\hline 35 & 56 & 0.8594 & 14.000 & 17.000 & 0 & 1 & 0 & 1 \\
\hline 36 & 32 & 2.3333 & 13.895 & 16.674 & 1 & 0 & 0 & 0 \\
\hline 37 & 16 & 0.9167 & 10.769 & 13.538 & 0 & 0 & 0 & 0 \\
\hline 38 & 12 & 1.1667 & 12.000 & 8.550 & 0 & 0 & 1 & 0 \\
\hline 39 & 12 & 0.5000 & 3.800 & 3.400 & 1 & 0 & 0 & 0 \\
\hline 40 & 160 & 0.7000 & 12.000 & 15.086 & 0 & 0 & 0 & 0 \\
\hline 41 & 96 & 1.3333 & 23.333 & 29.333 & 0 & 0 & 0 & 1 \\
\hline 42 & 56 & 0.8000 & 11.880 & 7.800 & 0 & 1 & 0 & 1 \\
\hline 43 & 24 & 0.9375 & 7.778 & 9.778 & 0 & 1 & 0 & 1 \\
\hline 44 & 42 & 1.2500 & 1.458 & 1.833 & 0 & 1 & 0 & 1 \\
\hline 45 & 126 & 1.4286 & 29.025 & 29.250 & 0 & 0 & 0 & $i$ \\
\hline 46 & 72 & 0.6667 & 5.556 & 6.222 & 1 & 0 & 0 & 0 \\
\hline 47 & 48 & 0.6667 & 5.833 & 7.333 & 1 & 0 & 0 & 0 \\
\hline 48 & 60 & 0.6000 & 9.900 & 6.500 & 0 & 1 & 0 & 0 \\
\hline 49 & 8 & 4.5000 & 23.800 & 19.800 & 0 & 0 & 1 & 1 \\
\hline 50 & 35 & 0.7333 & 22.680 & 18.360 & 0 & 0 & 1 & 1 \\
\hline 51 & 64 & 1.3125 & 7.000 & 8.800 & 0 & 1 & 0 & 0 \\
\hline 52 & 76 & 0.6875 & 6.417 & 8.067 & 1 & 0 & 0 & 0 \\
\hline 53 & 122 & 0.8333 & 7.000 & 8.800 & 0 & 1 & 0 & 1 \\
\hline 54 & 88 & 0.9688 & 10.182 & 12.800 & 0 & 0 & 0 & 1 \\
\hline 55 & 56 & 1.5000 & 8.750 & 11.000 & 0 & 0 & 1 & 1 \\
\hline
\end{tabular}


TABLE XXXII (Continued)

\begin{tabular}{|c|c|c|c|c|c|c|c|c|}
\hline OBS & $R$ & P 1 & P2 & P3 & D4 & 05 & D6 & D7 \\
\hline 56 & 34 & 0.9375 & 6.774 & 8.516 & 1 & 0 & 0 & 0 \\
\hline 57 & 40 & 0.2857 & 5.147 & 6.471 & 1 & 0 & 0 & 0 \\
\hline 58 & 6 & 42.6667 & 161.129 & 161.129 & 1 & 0 & 0 & 1 \\
\hline 59 & 16. & 3. 3333 & 22.575 & 22.750 & 0 & 0 & 0 & $i$ \\
\hline 60 & 32 & 0.6875 & 10.182 & 12.800 & 1 & 0 & 0 & 0 \\
\hline 61 & 48 & 1.5833 & 12.250 & 15.400 & 0 & 1 & 0 & 1 \\
\hline 62 & 186 & 0.7778 & 13.208 & 16.604 & 0 & 0 & 1 & 1 \\
\hline 63 & 78 & 0.3667 & 3.750 & 3.875 & 1 & 0 & 0 & 0 \\
\hline 64 & 16 & 1.8750 & 14.437 & 9.479 & 0 & 0 & 0 & 1 \\
\hline 65 & 16 & 1.3125 & 28.800 & 22.500 & 0 & 0 & 1 & $i$ \\
\hline 66 & 98 & 0.7813 & 10.000 & 12.571 & 0 & 1 & 0 & 1 \\
\hline 67 & 18 & 0.7222 & 9.800 & 12.320 & 0 & 0 & 0 & 1 \\
\hline 68 & 21 & 0.8000 & 21.818 & 22.545 & 0 & 1 & 0 & 0 \\
\hline 69 & 8 & 2.2500 & 10.971 & 8.571 & 0 & $i$ & 0 & 0 \\
\hline 70 & 32 & 0.2500 & 2.000 & 2.067 & 1 & 0 & 0 & 0 \\
\hline 71 & 96 & 1.2500 & 12.160 & 13.600 & 0 & 0 & 1 & 1 \\
\hline 72 & 135 & 1.0556 & 4.714 & 5.304 & 0 & 0 & 0 & 0 \\
\hline 73 & 24 & 0.4167 & 13.026 & 8.553 & 0 & 1 & 0 & 0 \\
\hline 74 & 96 & 1.0833 & 3.484 & 5.081 & 0 & 0 & 1 & 0 \\
\hline 75 & 336 & 0.5179 & 80.625 & 76.875 & 0 & 0 & 0 & 0 \\
\hline 76 & 84 & 1.2698 & 48.818 & 49.636 & 0 & 1 & 0 & 0 \\
\hline 77 & 336 & 0.6833 & 9.722 & 12.222 & 0 & 0 & 1 & 1 \\
\hline 78 & 432 & 0.2222 & 20.000 & 18.800 & 1 & 0 & 0 & $i$ \\
\hline 79 & 81 & 1.1944 & 31.111 & 39.111 & $i$ & 0 & 0 & $i$ \\
\hline 80 & 105 & 0.4800 & 14.550 & 18.300 & 0 & 0 & 1 & 0 \\
\hline 81. & 6 & 1.0111 & 12.096 & 12.000 & 0 & 0 & 1 & 0 \\
\hline 82 & 32 & 2.1667 & 11.733 & 13.200 & 0 & 1 & 0 & 1 \\
\hline 83 & 64 & 1.5625 & 14.000 & 17.600 & 0 & 0 & 1 & 1 \\
\hline 84 & 36 & 1.3889 & 5.833 & 7.333 & 0 & 0 & 0 & 1 \\
\hline 85 & 90 & 0.8056 & 8.250 & 8.125 & 0 & 1 & 0 & 1 \\
\hline 86 & 10 & 1.3000 & 11.455 & 14.400 & 0 & 1 & 0 & 1 \\
\hline 87 & 10 & 1.6000 & 15.273 & 19.200 & 0 & 1 & 0 & 1 \\
\hline 88 & 124 & 0.6944 & 16.333 & 20.533 & 0 & 0 & 0 & 1 \\
\hline 89 & 32 & 0.1250 & 5.375 & 5.125 & 0 & 1 & 0 & 0 \\
\hline 90 & 8 & 2.0625 & 14.190 & 14.300 & 0 & 0 & 0 & 0 \\
\hline 91 & 48 & 1.1111 & 14.000 & 17.600 & 0 & 1 & 0 & 1 \\
\hline 92 & 16 & 4.2500 & 26.250 & 33.000 & 0 & 1 & 0 & 1 \\
\hline 93 & 8 & 3.9100 & 23.870 & 30.008 & 1 & 0 & 0 & 1 \\
\hline 94 & 32 & 1.7500 & 7.000 & 8.800 & 0 & 1 & 0 & $i$ \\
\hline 95 & 20 & 3.2000 & 28.062 & 34.685 & 1 & 0 & 0 & 1 \\
\hline 96 & 180 & 0.2500 & 5.000 & 5.167 & 0 & 1 & 0 & 0 \\
\hline 97 & 72 & 0.6667 & 4.000 & 4.133 & 1 & 0 & 0 & 0 \\
\hline 98 & 4 & 1.7500 & 1.429 & 4.429 & 1 & 0 & 0 & 0 \\
\hline 99 & 72 & 1.2000 & 20.000 & 39.667 & 0 & 0 & 1 & 0 \\
\hline 100 & 147 & 0.5238 & 9.333 & 11.733 & 0 & 0 & 1 & 1 \\
\hline 101 & 225 & 1.0000 & 14.000 & 17.600 & 0 & 0 & i & 1 \\
\hline 102 & 96 & 0.5000 & 10.133 & 7.600 & 0 & 0 & 1 & 1 \\
\hline 103 & 25 & 1.2000 & 20.408 & 24.490 & 0 & 0 & 0 & 0 \\
\hline 104 & 96 & 1.1667 & 13.200 & 13.000 & 0 & 0 & 0 & 0 \\
\hline 105 & 96 & 2.0000 & 10.889 & 13.689 & 1 & 0 & 0 & 1 \\
\hline 106 & 48 & 0.9444 & 10.465 & 12.977 & 0 & 1 & 0 & 1 \\
\hline 107 & 62 & 0.7500 & 5.000 & 5.200 & 0 & 0 & 0 & 1 \\
\hline 108 & 15 & 0.3333 & 3.800 & 4.900 & 0 & 1 & 0 & 1 \\
\hline 109 & 42 & 0.9028 & 26.222 & 28.667 & 0 & 0 & 0 & 1 \\
\hline 110 & 48 & 6.0000 & 60.000 & 62.000 & 1 & 0 & 0 & 1 \\
\hline
\end{tabular}


TABLE XXXII (Continued)

\begin{tabular}{|c|c|c|c|c|c|c|c|c|}
\hline OBS & $R$ & $\mathrm{Pl}$ & $P 2$ & P3 & D4 & D5 & D6 & D7 \\
\hline 111 & 72.0 & 2.00000 & 25.455 & 32.000 & 1 & 0 & 0 & 0 \\
\hline 112 & 12.0 & 0.50000 & 5.250 & 6.600 & 1 & 0 & 0 & 1 \\
\hline 113 & 24.0 & 1.66667 & 27.456 & 27.552 & 0 & 0 & 0 & $i$ \\
\hline 114 & 6.0 & 5.25000 & 18.000 & 15.700 & 0 & 1 & 0 & 0 \\
\hline 115 & 30.0 & 2.09524 & 28.400 & 29.600 & 1 & 0 & 0 & 0 \\
\hline 116 & 26.0 & 1.65385 & 42.708 & 36.111 & 1 & 0 & 0 & 0 \\
\hline $1 i 7$ & 10.0 & 1.10000 & 5.000 & 6.286 & 1 & 0 & 0 & 0 \\
\hline 118 & $42 \cdot 0$ & 0.90625 & 13.770 & 17.311 & 0 & 0 & 1 & 0 \\
\hline 119 & 28.0 & 0.76250 & 10.880 & 12.480 & 0 & 0 & $i$ & 1 \\
\hline 120 & 84.0 & 0.33333 & 22.500 & 23.000 & 0 & 1 & 0 & 0 \\
\hline 121 & 21.0 & 1.76190 & 25.800 & 28.200 & 0 & 0 & 1 & 0 \\
\hline 122 & 20.0 & 2.06818 & 44.088 & 51.095 & 1 & 0 & 0 & 0 \\
\hline 123 & 108.0 & 0.13095 & 6.870 & 7.000 & 0 & 1 & 0 & 1 \\
\hline 124 & 312.0 & 0.67308 & 21.000 & 26.400 & 1 & 0 & 0 & 1 \\
\hline 125 & 96.0 & 3.91667 & 24.960 & 30.720 & 0 & 0 & 1 & 1 \\
\hline 126 & 96.0 & 3.75000 & 23.333 & 29.333 & 0 & 0 & 0 & $i$ \\
\hline 127 & 72.0 & 7.91067 & 40.000 & 41.333 & 0 & 0 & 0 & 1 \\
\hline 128 & 145.0 & 0.67500 & 7.200 & 7.440 & 0 & 0 & 1 & $i$ \\
\hline 129 & 48.0 & 3.50958 & 21.202 & 22.977 & 0 & 0 & 0 & 0 \\
\hline 130 & 10.0 & 1.75000 & 12.900 & 14.100 & 0 & 0 & 1 & 1 \\
\hline 131 & 15.0 & 2.33333 & 19.200 & 36.000 & 0 & 0 & 0 & $i$ \\
\hline 132 & 20.0 & 2.25000 & 26.559 & 29.029 & 0 & 0 & 0 & 0 \\
\hline 133 & 6.0 & 3.16667 & 7.520 & 7.467 & 0 & 0 & 0 & 0 \\
\hline 134 & 48.0 & 1.12500 & 11.200 & 12.600 & 0 & 1 & 0 & 1 \\
\hline 135 & 64.0 & 0.46429 & 2.400 & 3. 500 & 0 & 1 & 0 & 0 \\
\hline 136 & 4.0 & 2.25000 & 17.500 & 18.083 & 0 & 0 & 1 & 0 \\
\hline 137 & 4.0 & 5.75000 & 18.375 & 19.950 & 0 & 0 & 1 & 0 \\
\hline 138 & 70.0 & 2.00000 & 4.000 & 4.133 & 1 & 0 & 0 & 1 \\
\hline 139 & 62.5 & 1.30000 & 30.217 & 32.826 & 0 & 0 & 1 & 0 \\
\hline 140 & 36.0 & 0.87500 & 2.000 & 6.200 & 0 & 0 & 0 & 0 \\
\hline 141 & 68.0 & 1.300 .00 & 13.500 & 13.800 & 1 & 0 & 0 & 1 \\
\hline 142 & 24.0 & 0.85714 & 13.200 & 13.000 & 0 & 1 & 0 & $i$ \\
\hline 143 & 57.0 & 0.88889 & 19.846 & 21.692 & 0 & 1 & 0 & 1 \\
\hline 144 & 90.0 & 2.68817 & 129.500 & 129.500 & 1 & 0 & 0 & 0 \\
\hline 145 & 14.0 & 8.57143 & 58.600 & 61.100 & $i$ & 0 & 0 & 0 \\
\hline 146 & 64.0 & 0.42857 & 16.800 & 21.120 & 0 & 0 & 0 & 0 \\
\hline 147 & 35.0 & 1.22500 & 20.286 & 21.143 & 0 & 1 & 0 & 0 \\
\hline 148 & 56.0 & 1.40278 & 16.650 & 16.650 & 1 & 0 & 0 & 0 \\
\hline 149 & 84.0 & 0.30000 & 8.000 & 10.400 & 0 & 0 & 1 & 0 \\
\hline 150 & 140.0 & 0.24176 & 6.500 & 8.300 & 0 & 0 & 0 & 0 \\
\hline 151 & 32.0 & 5.50000 & 30.000 & 32.700 & 0 & 0 & 0 & 0 \\
\hline 152 & 10.0 & 1.37500 & 7.000 & 8.800 & 1 & 0 & 0 & 1 \\
\hline 153 & 56.0 & 1.71429 & 21.000 & 26.400 & 1 & 0 & 0 & 0 \\
\hline 154 & 50.0 & 0.61667 & 9.638 & 11.147 & $i$ & 0 & 0 & 0 \\
\hline 155 & 96.0 & 0.77778 & 10.652 & 13.391 & 0 & 0 & 0 & 1 \\
\hline 156 & 96.0 & 1.11111 & 9.545 & 12.000 & 0 & 0 & 1 & 1 \\
\hline 157 & 24.0 & 1.00000 & 7.800 & 9.600 & 0 & 1 & 0 & 0 \\
\hline 158 & 42.0 & 0.74490 & 70.000 & 88.000 & 0 & 0 & 0 & 0 \\
\hline 159 & 32.0 & 1.25000 & 5.833 & 7.333 & 0 & 0 & 1 & 0 \\
\hline 160 & 14.0 & 1.57143 & 17.500 & 22.000 & 0 & 1 & 0 & 0 \\
\hline 161 & 6.0 & 4.50000 & 16.071 & 14.286 & 0 & 0 & 0 & 0 \\
\hline 162 & 140.0 & 0.46667 & 11.355 & 12.774 & 1 & 0 & 0 & 0 \\
\hline 163 & 16.0 & 1.00000 & 9.900 & 9.750 & 1 & 0 & 0 & 1 \\
\hline 164 & 14.0 & 0.35714 & 6.600 & 6.500 & 1 & 0 & 0 & 1 \\
\hline 165 & 63.0 & 0.88839 & 7.000 & 8.800 & 1 & 0 & 0 & 0 \\
\hline
\end{tabular}


TABLE XXXII (Continued)

\begin{tabular}{|c|c|c|c|c|c|c|c|c|}
\hline $\mathrm{OBS}$ & $R$ & P1 & P2 & P3 & D4 & D5 & D6 & D7 \\
\hline $\begin{array}{l}166 \\
167 \\
168 \\
169 \\
170 \\
171 \\
172 \\
173\end{array}$ & $\begin{array}{r}60 \\
144 \\
178 \\
30 \\
60 \\
56 \\
96 \\
128\end{array}$ & $\begin{array}{l}1.00758 \\
0.91667 \\
1.00000 \\
1.37500 \\
1.00000 \\
0.81250 \\
0.68750 \\
0.87500\end{array}$ & $\begin{array}{r}38.2308 \\
9.8000 \\
4.6667 \\
17.6000 \\
5.8667 \\
7.7000 \\
17.3077 \\
33.0000\end{array}$ & $\begin{array}{r}51.1538 \\
12.3200 \\
5.8667 \\
8.0000 \\
6.6000 \\
3.5000 \\
17.6923 \\
32.5000\end{array}$ & $\begin{array}{l}0 \\
0 \\
0 \\
1 \\
1 \\
0 \\
0 \\
0\end{array}$ & $\begin{array}{l}1 \\
1 \\
0 \\
0 \\
0 \\
0 \\
1 \\
0\end{array}$ & $\begin{array}{l}0 \\
0 \\
0 \\
0 \\
0 \\
0 \\
0 \\
1\end{array}$ & $\begin{array}{l}0 \\
1 \\
0 \\
0 \\
0 \\
0 \\
1 \\
1\end{array}$ \\
\hline
\end{tabular}


TABLE XXXIII

REGRESSION ANALYSIS DATA: EUFAULA LAKE

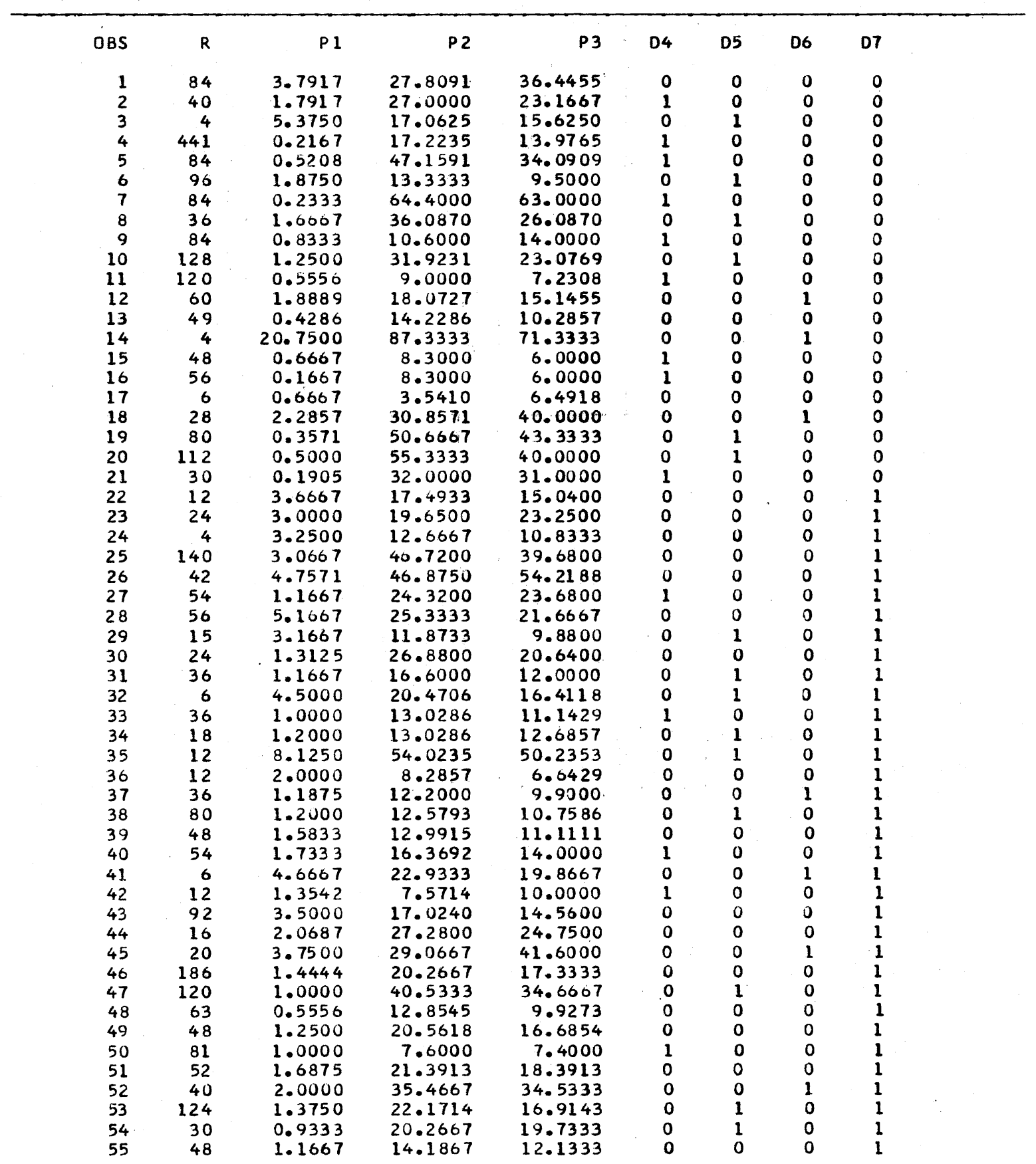


TABLE XXXIII (Continued)

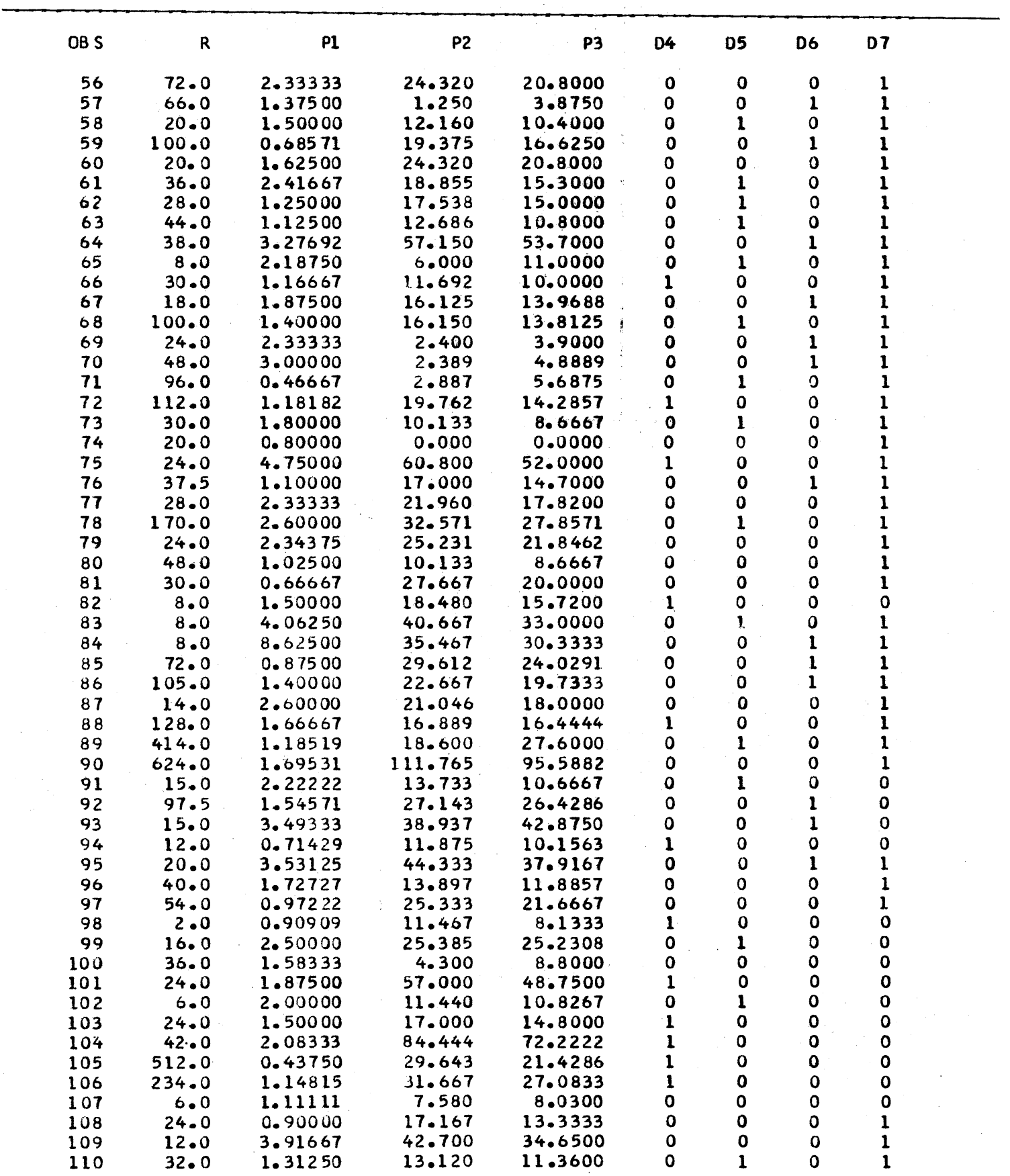


TABLE XXXIII (Continued)

\begin{tabular}{rrrrrrrrr}
\hline OBS & $R$ & $P 1$ & $P 2$ & $P 3$ & $D 4$ & $D 5$ & $D 6$ & $D 7$ \\
111 & 90 & 1.24000 & 29.2000 & 24.6000 & 0 & 0 & 0 & 1 \\
112 & 35 & 0.72727 & 32.5714 & 31.7143 & 0 & 0 & 0 & 1 \\
113 & 72 & 2.5000 & 12.6667 & 10.8333 & 0 & 0 & 0 & 1 \\
\hline
\end{tabular}




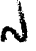 \\ VITA \\ Ronald Wayne Presley \\ Candidate for the Degree of \\ Doctor of Philosophy
}

Thesis: AN ECONOMIC ANALYSIS OF FEE VERSUS NON-FEE RECREATIONAL AREAS AT THREE OKLAHOMA LAKES

Major Field: Economics

Biographical :

Personal Data: Born in Wichita, Kansas, October 27, 1941, the son of Mr. and Mrs. A. H. Presley.

Education: Graduated from Wichita East High School, Wichita, Kansas, in 1959; received Bachelor of Business Administration degree in Economics from Wichita State University in 1970, received Master of Arts degree in Economics from Wichita State University in 1972; completed requirements for the Doctor of Philosophy degree at Oklahoma State University in December, 1975.

Professional Experience: Part-time Instructor, Hesston College, Hesston; Kansas, 1971; Part-time Instructor, Department of Economics, Wichita State University, 1972; graduate research assistant, Oklahoma State University, Department of Economics, 1972-73; Research Associate, Department of Agricultural Economics, Oklahoma State University, 1974-75; Visiting Assistant Professor, Department of Economics, Oklahoma State University, 1975-76。 